\title{
Cultivation of Mushrooms and Their Lignocellulolytic Enzyme Production Through the Utilization of Agro-Industrial Waste
}

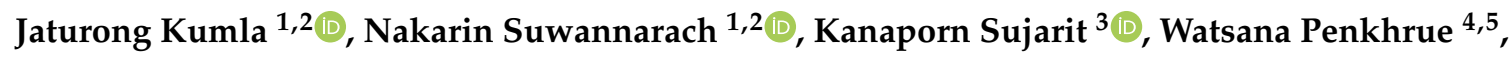 \\ Pattana Kakumyan ${ }^{6}$, Kritsana Jatuwong ${ }^{1,2}$, Santhiti Vadthanarat ${ }^{1,2}$ and \\ Saisamorn Lumyong 1,2,7,* \\ 1 Research Center of Microbial Diversity and Sustainable Utilization, Chiang Mai University, \\ Chiang Mai 50200, Thailand; jaturong_yai@hotmail.com (J.K.); suwan.462@gmail.com (N.S.); \\ aew.kritsana@gmail.com (K.J.); santhiti.v@gmail.com (S.V.) \\ 2 Department of Biology, Faculty of Science, Chiang Mai University, Chiang Mai 50200, Thailand \\ 3 Division of Biology, Faculty of Science and Technology, Rajamangala University of Technology Thanyaburi, \\ Thanyaburi, Pathumthani 12110, Thailand; kanaporn_s@rmutt.ac.th \\ 4 School of Preclinic, Institute of Science, Suranaree University of Technology, Nakhon Ratchasima 30000, \\ Thailand; watsanapenkhrue@gmail.com \\ 5 Center of Excellence in Microbial Technology for Agricultural Industry, Suranaree University of Technology, \\ Nakhon Ratchasima 30000, Thailand \\ 6 School of Science, Mae Fah Luang University, Chiang Rai 57100, Thailand; pattana.kak@mfu.ac.th \\ 7 Academy of Science, The Royal Society of Thailand, Bangkok 10300, Thailand \\ * Correspondence: scboi009@gmail.com; Tel.: +668-1881-3658
}

Academic Editor: George Zervakis

Received: 29 May 2020; Accepted: 15 June 2020; Published: 18 June 2020

\begin{abstract}
A large amount of agro-industrial waste is produced worldwide in various agricultural sectors and by different food industries. The disposal and burning of this waste have created major global environmental problems. Agro-industrial waste mainly consists of cellulose, hemicellulose and lignin, all of which are collectively defined as lignocellulosic materials. This waste can serve as a suitable substrate in the solid-state fermentation process involving mushrooms. Mushrooms degrade lignocellulosic substrates through lignocellulosic enzyme production and utilize the degraded products to produce their fruiting bodies. Therefore, mushroom cultivation can be considered a prominent biotechnological process for the reduction and valorization of agro-industrial waste. Such waste is generated as a result of the eco-friendly conversion of low-value by-products into new resources that can be used to produce value-added products. Here, we have produced a brief review of the current findings through an overview of recently published literature. This overview has focused on the use of agro-industrial waste as a growth substrate for mushroom cultivation and lignocellulolytic enzyme production.
\end{abstract}

Keywords: lignocellulosic materials; lignocellulolytic enzymes; mushroom cultivation; solid state fermentation

\section{Introduction}

The rapidly growing global population and expansion in the agriculture sector and food industries have resulted in the generation of a large amount of agro-industrial waste annually. Agro-industrial waste is defined as the waste that is generated during the industrial processing of agricultural or animal products or the waste obtained from agricultural activities [1,2]. The waste can further be divided into two types, agricultural residues and industrial residues, respectively [2-5]. Agricultural residues consist 
of field residues and process residues. Field residues are generated during the crop harvesting process and are made up of leaves, roots, stalks, straw, seed pods and stems. Process residues are generated during the further processing of the crops and are made up of husks, peels, pulp and shells. Asia is the largest producer of agricultural residues at $47 \%$, followed by the United States (29\%), Europe (16\%), Africa (6\%) and Oceania (2\%) [6]. Industrial residues are residues that are produced by the food, fruit and vegetable processing industries and include bran, peels, pomace and bagasse. Generally, most agro-industrial waste is disposed of in landfills or burned, leading to various environmental problems and pose potential harm to the health of humans and wildlife $[5,7,8]$. However, agro-industrial waste can potentially be converted into different high-value products, including biofuels, value-added fine chemicals and cheap energy sources for microbial fermentation and enzyme production [7-9]. These waste products can represent a source of energy, as well as sources of carbon. Additionally, this form of waste is a source of the nutrients that are required for mushroom growth and lignocellulolytic enzyme production via solid state fermentation [9-11]. Therefore, in this study, we have summarized the current findings on the use of agro-industrial waste as growth substrates for mushroom cultivation and lignocellulolytic enzyme production.

\section{The Composition of Agro-Industrial Wastes}

Agro-industrial waste is a major lignocellulosic component. This form of waste includes cellulose, hemicelluloses and lignin, which are normally referred to as "lignocellulosic materials". Generally, cellulose is the most abundant component, followed by hemicellulose and lignin (Figure 1).

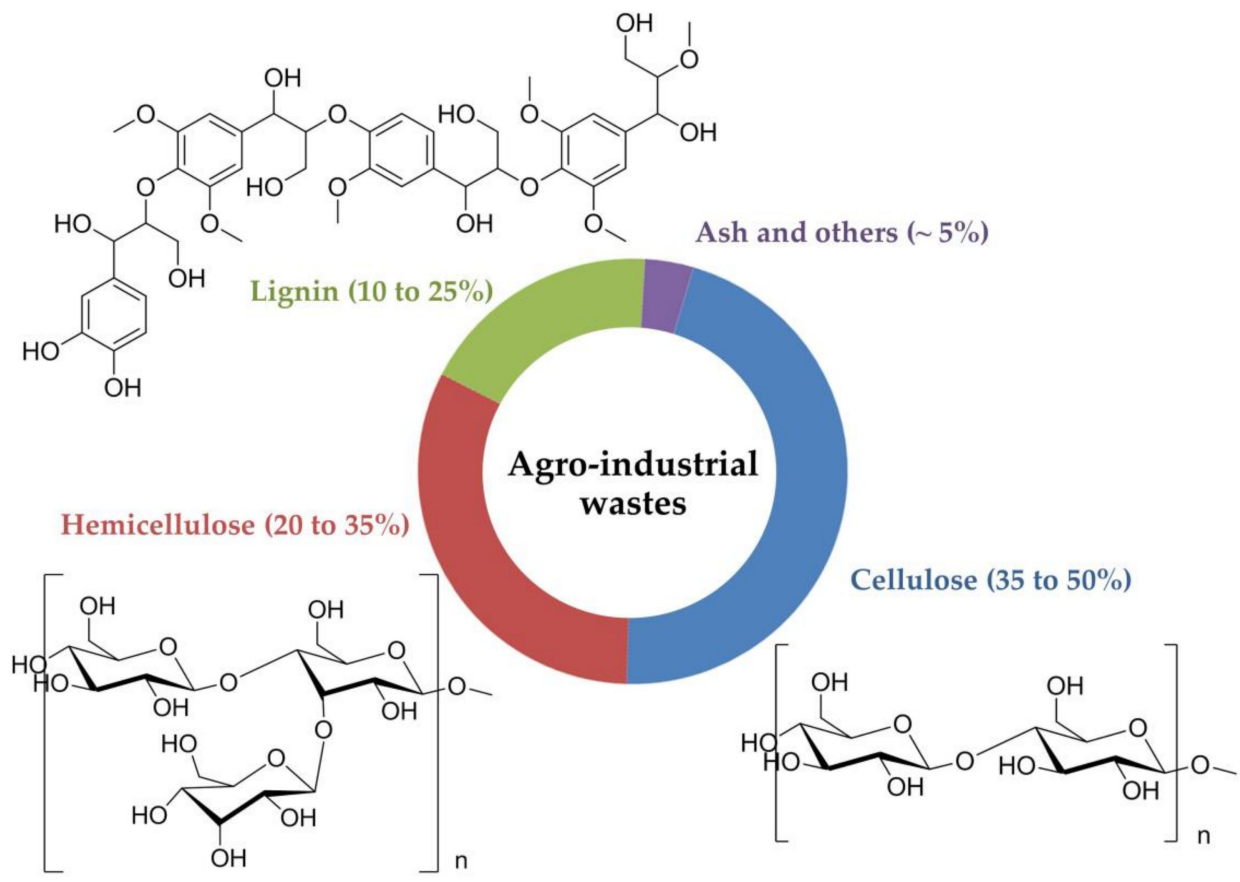

Figure 1. Main composition of agro-industrial wastes.

Cellulose is a homopolymer consisting of a linear chain of several hundred to many thousands of $\beta$-anhydroglucose units ( $\beta-1,4$ linked D-glucose units). Each of the $\beta$-anhydroglucose units consists of three hydroxyl groups $(\mathrm{OH})$, one primary (C6 position) and two secondary ( $\mathrm{C} 2$ and $\mathrm{C} 3$ positions) hydroxyl groups, each of which exhibits different polarities and is capable of being involved in the intra- and intermolecular hydrogen bonds $[12,13]$. The intra- and inter-chain hydrogen bonding network makes cellulose a relatively stable polymer and gives the cellulose fibrils high axial stiffness [14].

Hemicellulose is a heteropolymer consisting of a polysaccharide backbone. Its structure greatly varies depending on the sugar units, chain length and the branching of the chain molecules. Typical binding sugars in hemicelluloses are pentoses (xylose and arabinose), hexoses (mannose, glucose, 
and galactose), hexuronic acids (4-O-methyl-D-glucuronic acid, galacturonic acid, and glucuronic acid), small amounts of rhamnose and fucose, and an acetyl group [12]. These binding sugars can assemble into a range of various hemicellulose polysaccharides, such as galactan mannans, xylans, xyloglucan and $\beta-1,3 / 1,4$-glucans $[12,15]$.

Lignin is a rigid aromatic, amorphous and hydrophobic polymer that has been recognized as a highly branched polymer with a variety of functional groups, such as aliphatic, phenolic hydroxyls, carboxylic, carbonyl, and methoxyl groups. These functional groups give lignin a unique and very complex structure [16-18]. The nature of the lignin polymerization reactions results in the formation of a three dimensional, highly-branched, interlocking network of essentially infinite molecular weight. Lignin composition and content are influenced by plant species and the environment $[17,18]$.

The composition of cellulose, hemicellulose and lignin in agro-industrial waste depends upon the species, tissue and maturity of the plant $[2,4,5,12]$. The values of the main components in some agro-industrial waste are shown in Table 1.

Table 1. Main composition and carbon/nitrogen $(\mathrm{C} / \mathrm{N})$ ratio of some agro-industrial wastes.

\begin{tabular}{|c|c|c|c|c|c|}
\hline \multirow{2}{*}{ Agro-Industrial Wastes } & \multicolumn{3}{|c|}{ Composition (\% Dry Weight Basis) } & \multirow{2}{*}{$\begin{array}{c}\mathrm{C} / \mathrm{N} \\
\text { Ratio }\end{array}$} & \multirow{2}{*}{ Reference } \\
\hline & Cellulose & Hemicellulose & Lignin & & \\
\hline Apple pomace & 43 & 24 & 20 & $48 / 1$ & [19] \\
\hline Banana straw & 53 & 29 & 15 & $40 / 1$ & {$[20]$} \\
\hline Banana leaves & 55 & 20 & 25 & $38 / 1$ & [21] \\
\hline Barley straw & $23-33$ & $21-22$ & $14-19$ & $82-120 / 1$ & {$[22,23]$} \\
\hline Canola straw & 22 & 17 & 18 & $33-45 / 1$ & [23] \\
\hline Coconut husk & $24-43$ & $3-12$ & $25-45$ & $75-186 / 1$ & {$[24,25]$} \\
\hline Coffee husk & 43 & 7 & 9 & $40 / 1$ & [26] \\
\hline Corn bran & 34 & 39 & 49 & ND & {$[25]$} \\
\hline Corn cob & $35-45$ & $35-44$ & $11-15$ & $50-123 / 1$ & {$[27,28]$} \\
\hline Corn stalk & $34-61$ & $19-24$ & $7-9$ & $57-80 / 1$ & {$[25,29]$} \\
\hline Corn straw & 30 & 25 & 8 & $50 / 1$ & [25] \\
\hline Cotton stalk & 58 & 14 & 22 & $70-78 / 1$ & [22] \\
\hline Grasses & $25-41$ & $25-50$ & $7-30$ & $16-42 / 1$ & [30] \\
\hline Hardwoods & $40-55$ & $24-40$ & $18-25$ & $150-450 / 1$ & [30] \\
\hline Oat bran & 49 & 25 & 18 & $12 / 1$ & [25] \\
\hline Oat straw & $25-40$ & $21-27$ & $17-18$ & $48-83 / 1$ & {$[22,23]$} \\
\hline Rice bran & 35 & 25 & 17 & $12-48 / 1$ & [25] \\
\hline Rice husk & 35 & 25 & 20 & $30-80 / 1$ & [31] \\
\hline Rice straw & $32-39$ & $23-24$ & $18-36$ & $35-72 / 1$ & {$[29,32]$} \\
\hline Rye straw & 38 & 31 & 19 & $82 / 1$ & [22] \\
\hline Beech sawdust & 41 & 33 & 22 & $100-331 / 1$ & [33] \\
\hline Birch sawdust & 40 & 36 & 20 & $700 / 1$ & [33] \\
\hline Oak sawdust & $25-38$ & $18-29$ & $18-25$ & $162-200 / 1$ & {$[31,33]$} \\
\hline Pine sawdust & 42 & 25 & 28 & $724-1070 / 1$ & [33] \\
\hline Poplar sawdust & 44 & 32 & 21 & $46-71 / 1$ & [33] \\
\hline Rubber tree sawdust & 38 & 25 & 15 & $177 / 1$ & [34] \\
\hline Spruce sawdust & 42 & 26 & 28 & $763-1000 / 1$ & [33] \\
\hline Softwood & $45-50$ & $25-35$ & $25-35$ & $310-520 / 1$ & [30] \\
\hline Sorghum stalk & 17 & 25 & 11 & $45 / 1$ & [25] \\
\hline Sorghum straw & 36 & 26 & 8 & $20-46 / 1$ & {$[35,36]$} \\
\hline Pineapple leaf & 36 & 23 & 27 & $49 / 1$ & [37] \\
\hline Pineapple peel & 22 & 75 & 3 & $77 / 1$ & [38] \\
\hline Potato peel & 35 & 5 & 4 & $25 / 1$ & [39] \\
\hline Orange peel & $9-14$ & $6-11$ & $1-2$ & $102 / 1$ & {$[40,41]$} \\
\hline Lemon peel & 12 & 5 & 2 & ND & [41] \\
\hline Tomato pomace & 9 & 5 & 5 & ND & [42] \\
\hline Banana peel & 12 & 10 & 3 & $18-29 / 1$ & [22] \\
\hline
\end{tabular}


Table 1. Cont.

\begin{tabular}{cccccc}
\hline \multirow{2}{*}{ Agro-Industrial Wastes } & \multicolumn{2}{c}{ Composition (\% Dry Weight Basis) } & \multicolumn{2}{c}{ C/N } & Reference \\
\cline { 2 - 4 } & Cellulose & Hemicellulose & Lignin & Ratio & \\
\hline Soya stalk & 35 & 25 & 20 & $20-40 / 1$ & {$[43]$} \\
Sugarcane bagasse & $30-45$ & $26-36$ & $11-23$ & $50 / 1$ & {$[22,29,44]$} \\
Sugarcane straw & $36-41$ & $21-31$ & $16-26$ & $70-120 / 1$ & {$[45,46]$} \\
Sunflower stalk & 42 & 30 & 13 & $97 / 1$ & {$[43]$} \\
Oil palm empty fruit & $45-51$ & $28-29$ & $12-15$ & $77 / 1$ & {$[47,48]$} \\
bunch & 21 & 34 & 7 & $11 / 1$ & {$[10]$} \\
Water hyacinth & 30 & 50 & 15 & $19 / 1$ & {$[25]$} \\
Wheat bran & $27-38$ & $21-29$ & $18-21$ & $50-80 / 1$ & {$[22,25,49]$} \\
Wheat straw & 36 & 28 & 43 & $175 / 1$ & {$[50]$} \\
Walnut shell & 38 & 29 & 30 & $61 / 1$ & {$[51]$} \\
Almond shell & 21 & 16 & 36 & $8 / 1$ & {$[51]$} \\
Chestnut shell & 43 & 25 & 16 & $43 / 1$ & {$[51]$} \\
Pistachio shell & 55 & 34 & 35 & $50-58 / 1$ & {$[52]$} \\
Hazelnut shell & 31 & 21 & 26 & $14-17 / 1$ & {$[53]$} \\
Olive oil cake & 64 & 15 & 5 & ND & {$[54]$} \\
Oil palm cake & 25 & 12 & 8 & ND & {$[54]$} \\
Sunflower oil cake & 31 & 20 & 18 & $59-67 / 1$ & {$[55]$} \\
Cotton seed hull & & & & &
\end{tabular}

"ND" = not determined.

\section{Mushroom Cultivation on Agro-Industrial Wastes}

Mushroom cultivation is widespread throughout the world and its global production has significantly increased since 2010 (Figure 2). The Food and Agriculture Organization Statistical Database (FAOSTAT) reported that China is the largest mushroom producer, followed by the United States of America and the Netherlands, with global production in 2018 reaching almost 8.99 million tons. The trend to increase mushroom production is expected to continue in the future.

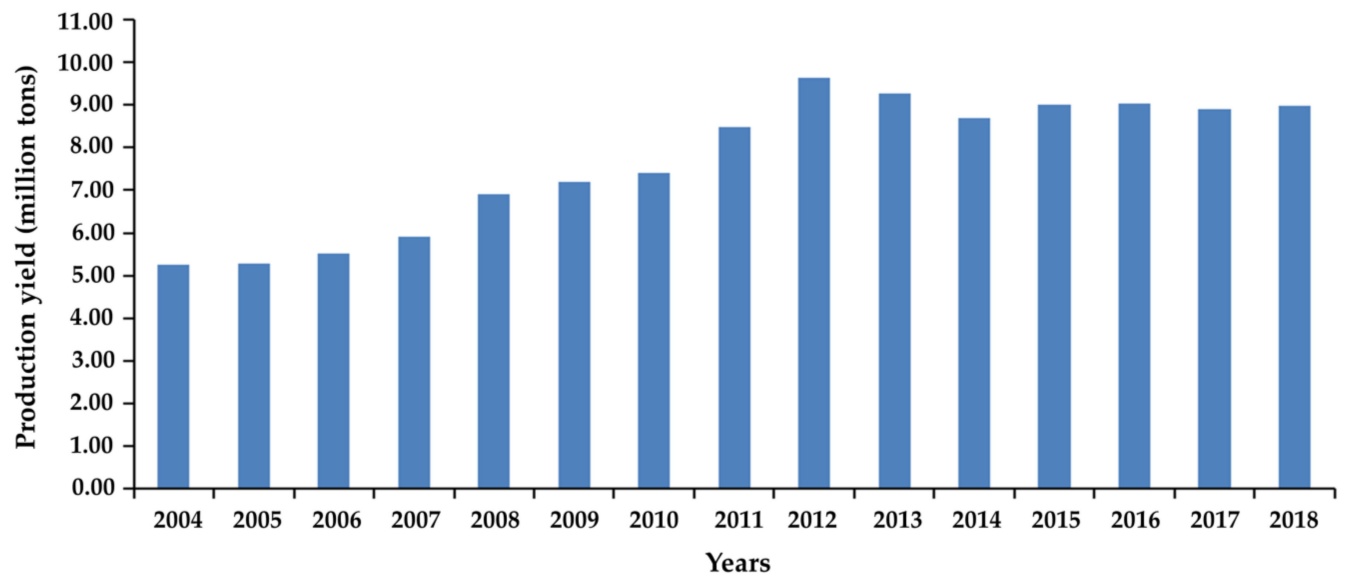

Figure 2. Data of global mushroom production during 2004-2018 from FAOSTAT [56].

Edible mushrooms are also considered a healthy food because they are rich in proteins, carbohydrates, fiber, vitamins and minerals while being low in fat $[57,58]$. Normally, the range of protein, carbohydrate and fat contents in mushrooms is $15-35 \%, 35-70 \%$ and less than $5 \%$, respectively [58]. Notably, several species of edible mushrooms are important because of their medicinal properties. Some edible mushrooms appear to be active against human pathogens, cancer, diabetes, hypertension, hypercholesterolemia conditions and tumors [57-59]. Today, more than 50 species of edible mushrooms have been commercially cultivated throughout the world. Most commercial edible mushrooms belong to the genera Agaricus, Agrocybe, Auricularia, Flammulina, Ganoderma, Hericium, 
Lentinula, Lentinus, Pleurotus, Tremella, and Volvariella (Figure 3). The top four globally cultivated edible mushrooms include the genera Lentinula (shiitake and relatives), Pleurotus (oyster mushroom), Auricularia (wood ear mushroom) and Agaricus (button mushroom and relatives) [54,60]. In 2017, world mushroom production was divided among several genera: Lentinula (22\%), Pleurotus (19\%), Auricularia (18\%), Agaricus (15\%), Flammulina (11\%), Volvariella (5\%) and others (10\%) [60]. Most of the cultivated edible mushrooms are saprophytic fungi (decomposers) and able to degrade lignocellulosic materials by producing extensive enzymes (especially lignocellulolytic enzymes). They are then able to use these materials as nutrients for their growth. Thus, mushroom cultivation is often associated with the recycling of vast amounts of agro-industrial waste [2-4,54].

Agro-industrial wastes (both agricultural residue and industrial residue) have been used as substrates in mushroom cultivation. Most agro-industrial waste is defined as low nitrogen content materials. The carbon/nitrogen $(\mathrm{C} / \mathrm{N})$ ratio in agro-industrial waste is varied among different types (Table 1), and it is an important factor in mushroom cultivation. This ratio has a critical influence on mycelium growth, mushroom weight, yields and protein content in the fruiting body of mushrooms $[11,61,62]$. Therefore, low-level nitrogen substrates for mushroom cultivation are necessary in that they add organic (cereal bran, cereal shell, soybean meal and manure) or inorganic (ammonium chloride and urea) nitrogen supplements $[63,64]$. Several previous studies have found that the protein content in the fruiting body of mushrooms depends upon both the chemical composition and the $\mathrm{C} / \mathrm{N}$ ratio of substrates, as well as the species of mushroom being cultivated [1,64-66]. Different mushroom species require different $\mathrm{C} / \mathrm{N}$ ratios in the cultivation substrate in order to obtain the highest production yield, as is shown in Table 2. Moreover, the addition of various supplements, e.g., epsom salts $\left(\mathrm{MgSO}_{4} \cdot 7 \mathrm{H}_{2} \mathrm{O}\right)$, gypsum $\left(\mathrm{CaSO}_{4} \cdot 2 \mathrm{H}_{2} \mathrm{O}\right)$ and limestone (calcium carbonate, $\left.\mathrm{CaCO}_{3}\right)$, in the substrates also support the mycelia growth and fruiting body production of mushrooms [11,61,67].

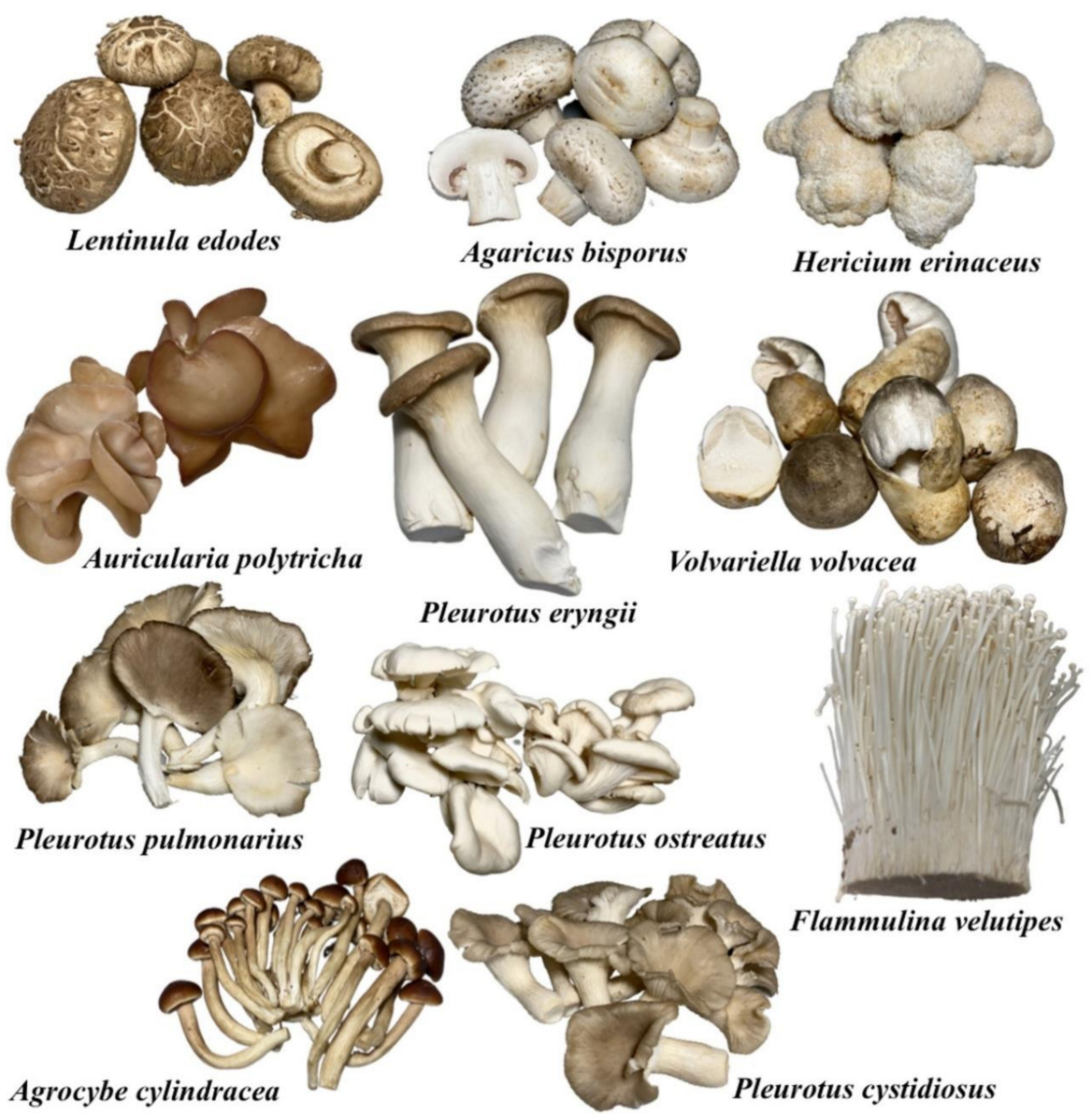

Figure 3. Examples of some commercially important cultivated mushrooms. 
Table 2. The carbon/nitrogen ratio in substrate to obtain the highest yield of some mushroom species.

\begin{tabular}{ccccc}
\hline \multirow{2}{*}{ Mushroom Species } & \multicolumn{3}{c}{ C/N Ratio (\%) } & \multirow{2}{*}{ Reference } \\
\cline { 2 - 4 } & Minimum & Optimum & Maximum & \\
\hline Agaricus bisporus & $16 / 1$ & $19 / 1$ & $22 / 1$ & {$[68]$} \\
Agaricus bitorquis & $16 / 1$ & $19 / 1$ & $22 / 1$ & {$[69]$} \\
Agaricus brasiliensis & $10 / 1$ & $26-28 / 1$ & $50 / 1$ & {$[70]$} \\
Agaricus brunescens & $16 / 1$ & $19 / 1$ & $21 / 1$ & {$[71]$} \\
Agaricus subrufescens & $16 / 1$ & $27 / 1$ & $33 / 1$ & {$[72]$} \\
Lentinula edodes & $25 / 1$ & $30-35 / 1$ & $55 / 1$ & {$[73]$} \\
Lentinus sajor-caju & $40 / 1$ & $45-55 / 1$ & $90 / 1$ & {$[74]$} \\
Pleurotus cornucopiae & $40 / 1$ & $45-55 / 1$ & $97 / 1$ & {$[75]$} \\
Pleurotus eryngii & $40 / 1$ & $45-55 / 1$ & $70 / 1$ & {$[75]$} \\
Pleurotus flabellatus & $40 / 1$ & $45-60 / 1$ & $100 / 1$ & {$[76]$} \\
Pleurotus florida & $40 / 1$ & $45-60 / 1$ & $150 / 1$ & {$[77,78]$} \\
Pleurotus ostreatus & $40 / 1$ & $45-60 / 1$ & $90 / 1$ & {$[78]$} \\
Flammulina velutipes & ND & $30 / 1$ & ND & {$[79]$} \\
Ganoderma lucidum & ND & $70-80 / 1$ & ND & {$[80]$} \\
Volvariella volvacea & ND & $40-60 / 1$ & ND & {$[81]$} \\
\hline
\end{tabular}

"ND" = not determined.

Biological efficiency (BE), which is used to evaluate the efficiency of substrate conversion in mushroom cultivation, is calculated as the percentage ratio of the fresh weight of harvested mushrooms over the dry weight of the cultivation substrate [67]. A high BE value ensures a high possibility of utilizing substrates for mushroom cultivation $[67,82]$. In considering the profitability of mushroom cultivation, the $\mathrm{BE}$ value must be over $50 \%$. Utilization of agro-industrial waste for the cultivation of mushrooms has resulted in the production of edible proteins for human consumption $[2,7,11]$. Cultivation methods for edible mushrooms vary considerably around the world and a variation in the chemical composition of a particular cultivated mushroom has been observed in various studies. This may be related to the specific mushroom species, the growing substrate and the relevant environmental conditions [1,2,11]. Many studies have been conducted to test the ability of mushrooms to grow on different agro-industrial forms of waste, such as wheat straw, barley straw, oat straw, rice straw, corn straw, corn cob, banana leaves, sawdust, sugarcane bagasse, soya stalk and sunflower stalk. A combination of agro-industrial waste can be used in mushroom cultivation. The main results regarding the cultivation of edible mushrooms on different agro-industrial waste, and their proximate composition values, are shown in Tables 3 and 4 . 
Table 3. Biological efficiency and chemical composition of some mushrooms grown on the non-combination of agro-industrial wastes.

\begin{tabular}{|c|c|c|c|c|c|c|c|c|}
\hline \multirow{2}{*}{$\begin{array}{l}\text { Agro-Industrial } \\
\text { Wastes }\end{array}$} & \multirow{2}{*}{ Mushroom Species } & \multirow{2}{*}{$\begin{array}{c}\text { Biological } \\
\text { Efficacy }(\%)\end{array}$} & \multicolumn{5}{|c|}{ Chemical Composition (\% Dry Weight) } & \multirow{2}{*}{ Reference } \\
\hline & & & Crude Protein & Carbohydrate & Fat & Fiber & Ash & \\
\hline \multirow{13}{*}{ Wheat straw } & Agaricus bisporus & $47.2-51.1$ & $21.0-27.0$ & $38.0-48.0$ & $3.0-4.0$ & $17.0-23.3$ & $8.0-11.0$ & {$[83,84]$} \\
\hline & Agaricus subrufescens & 53.7 & 28.4 & 63.2 & 1.6 & 6.2 & 6.8 & [85] \\
\hline & Agrocybe cylindracea & 61.4 & 1.5 & 89.6 & 0.3 & 40.4 & 8.6 & [86] \\
\hline & Hericium erinaceus & $39.4-43.5$ & 26.8 & 58.9 & 3.7 & ND & 10.5 & [87] \\
\hline & Lentinula edodes & $66.0-93.1$ & $15.2-15.4$ & $63.7-65.7$ & $1.1-1.5$ & ND & $3.8-4.4$ & [88] \\
\hline & Lentinus sajor-caju & 74.9 & 22.9 & 56.0 & 2.6 & 7.1 & 6.6 & [89] \\
\hline & Pleurotus citrinopileatus & 98.3-105.6 & 25.3 & 64.0 & 2.7 & ND & 8.1 & [90] \\
\hline & Pleurotus columbinus & 69.2 & 2.9 & 25.9 & 0.42 & 5.4 & 8.5 & [91] \\
\hline & Pleurotus eous & 75.1 & 19.5 & 50.2 & 2.6 & 7.8 & 6.0 & [92] \\
\hline & Pleurotus eryngii & 48.2 & 21.5 & 56.0 & 2.4 & 13.5 & 7.6 & [93] \\
\hline & Pleurotus florida & 66.4 & 27.9 & 51.2 & 2.4 & 12.2 & 8.7 & [94] \\
\hline & Pleurotus ostreatus & $22.6-52.6$ & $11.6-14.6$ & $47.5-74.4$ & $1.8-2.5$ & $19.1-27.1$ & $8.6-12.0$ & {$[86,95]$} \\
\hline & Pleurotus sapidus & 62.2 & 14.9 & 48.5 & 2.0 & 7.3 & 6.2 & [96] \\
\hline \multirow{2}{*}{ Barley straw } & Lentinula edodes & $64.1-88.6$ & $15.1-16.8$ & $75.1-77.7$ & $1.9-2.2$ & ND & $5.2-5.8$ & [88] \\
\hline & Pleurotus ostreatus & 21.3 & 12.8 & 54.7 & 29.9 & 0.9 & 1.2 & [95] \\
\hline Oat straw & Agaricus bisporus & $47.2-52.9$ & $26.8-36.2$ & ND & $2.3-3.1$ & $6.6-10.3$ & $9.8-11.3$ & [97] \\
\hline \multirow{13}{*}{ Rice straw } & Lentinula edodes & 48.7 & 16.2 & 78.0 & 6.0 & 1.5 & 3.4 & [99] \\
\hline & Lentinus sajor-caju & 78.3 & 23.4 & 55.0 & 2.4 & 7.9 & 6.8 & [89] \\
\hline & Hericium erinaceus & 33.9 & 24.1 & 60.5 & 4.2 & ND & 11.3 & [87] \\
\hline & Pleurotus citrinopileatus & $76.5-89.2$ & 22.8 & 64.9 & 3.2 & ND & 91 & {$[90]$} \\
\hline & Pleurotus columbinus & 71.4 & 4.8 & 27.3 & 0.3 & 5.0 & 7.7 & [91] \\
\hline & Pleurotus eous & 79.8 & 29.3 & 48.0 & 2.4 & 8.0 & 6.2 & [92] \\
\hline & Pleurotus eryngii & 45.9 & 21.8 & 53.0 & 1.9 & 13.8 & 8.7 & [93] \\
\hline & Pleurotus pulmonarius & 23.5 & 21.1 & ND & 5.2 & 7.0 & 6.9 & [100] \\
\hline & Pleurotus ostreatus & $25.6-84.6$ & $12.5-23.4$ & $55.3-57.4$ & $2.8-16.2$ & $7.7-0.7$ & $6.3-13.6$ & {$[95,101]$} \\
\hline & Pleurotus sapidus & 64.7 & 23.4 & 45.6 & 1.6 & 8.0 & 6.4 & [96] \\
\hline & Pleurotus djamor & 82.7 & 24.8 & 37.7 & 3.1 & 22.0 & 8.3 & [102] \\
\hline & Volvariella volvacea & $10.2-15.0$ & $36.9-38.1$ & $42.8-42.3$ & $0.8-1.0$ & $4.4-6.0$ & $9.0-10.3$ & [103-105] \\
\hline & Corprinus comatus & 18.0 & 10.9 & 76.6 & 1.9 & ND & 20.5 & [106] \\
\hline \multirow{2}{*}{ Corn straw } & Pleurotus florida & 31.6 & 26.3 & 31.3 & 0.5 & 19.6 & 5.2 & [107] \\
\hline & Volvariella volvacea & ND & 23.0 & 13.9 & 1.4 & 36.6 & 11.9 & [108] \\
\hline
\end{tabular}


Table 3. Cont

\begin{tabular}{|c|c|c|c|c|c|c|c|c|}
\hline \multirow{2}{*}{$\begin{array}{l}\text { Agro-Industrial } \\
\text { Wastes }\end{array}$} & \multirow{2}{*}{ Mushroom Species } & \multirow{2}{*}{$\begin{array}{l}\text { Biological } \\
\text { Efficacy (\%) }\end{array}$} & \multicolumn{5}{|c|}{ Chemical Composition (\% Dry Weight) } & \multirow{2}{*}{ Reference } \\
\hline & & & Crude Protein & Carbohydrate & Fat & Fiber & Ash & \\
\hline \multirow{6}{*}{ Corn cob } & Agrocybe cylindracea & 33.5 & 14.8 & 72.4 & 2.9 & 17.0 & 10.1 & [86] \\
\hline & Pleurotus columbinus & 79.1 & 1.9 & 28.5 & 0.2 & 4.12 & 9.3 & [91] \\
\hline & Pleurotus cystidiosus & 50.1 & 24.5 & 40.6 & 3.0 & 24.3 & 7.57 & [109] \\
\hline & Pleurotus eryngii & 51.8 & 23.8 & 54.8 & 1.9 & 9.7 & 7.0 & [93] \\
\hline & Pleurotus florida & 55.0 & 29.1 & 38.2 & 0.9 & 22.8 & 3.5 & [107] \\
\hline & Pleurotus ostreatus & $31.7-66.1$ & $15.4-29.7$ & $30.8-73.4$ & $2.7-3.4$ & $13.8-29.8$ & $7.1-8.0$ & {$[86,109]$} \\
\hline \multirow[t]{2}{*}{ Banana leaves } & Pleurotus pulmonarius & 17.9 & $16.9-23.5$ & 26.2 & $1.9-5.5$ & $5.8-7.2$ & $6.4-10.3$ & {$[62,100]$} \\
\hline & Volvariella volvacea & 15.2 & 23.9 & ND & ND & 8.1 & 6.1 & [111] \\
\hline \multirow{6}{*}{ Soya stalk } & Lentinus sajor-caju & 83.0 & 25.8 & 52.2 & 2.8 & 6.7 & 7.3 & [89] \\
\hline & Pleurotus eous & 82.3 & 30.5 & 50.5 & 2.6 & 9.0 & 6.5 & [92] \\
\hline & Pleurotus ostreatus & 85.2 & 24.7 & 53.2 & 2.8 & 7.2 & 6.7 & [101] \\
\hline & Pleurotus columbinus & 90.6 & 7.4 & 33.3 & 0.4 & 5.1 & 9.2 & [91] \\
\hline & Pleurotus florida & 87.6 & 23.5 & 57.8 & 2.5 & 8.0 & 8.0 & [112] \\
\hline & Pleurotus sapidus & 72.7 & 26.8 & 24.9 & 2.1 & 7.5 & 7.0 & [96] \\
\hline \multirow{2}{*}{ Sunflower stalk } & Pleurotus eous & 61.5 & 27.4 & 52.0 & 2.2 & 7.9 & 5.2 & [92] \\
\hline & Pleurotus sapidus & 45.9 & 20.1 & 48.5 & 2.4 & 7.3 & 6.2 & [96] \\
\hline \multirow{2}{*}{$\begin{array}{l}\text { Oil palm empty } \\
\text { fruit bunch }\end{array}$} & Schizopyllum commune & 3.7 & 6.1 & 37.4 & 4.5 & 0.01 & 1.94 & [113] \\
\hline & Volvariella volvacea & $3.6-6.5$ & $33.5-41.0$ & $27.9-45.7$ & $3.7-5.1$ & $7.7-16.0$ & $9.4-9.9$ & [114] \\
\hline \multirow{3}{*}{ Cotton stalk } & Pleurotus florida & 25.1 & 29.8 & 37.3 & 2.2 & 19.4 & 8.7 & [115] \\
\hline & Pleurotus pulmonarius & 42.3 & 29.3 & 44.5 & 3.1 & 11.3 & 9.2 & [115] \\
\hline & Pleurotus ostreatus & 44.3 & 30.1 & 40.2 & 2.1 & 17.2 & 8.4 & [115] \\
\hline Rice husk & Pleurotus ostreatus & 9.5 & 5.9 & 48.5 & 30.9 & 0.3 & 14.3 & {$[95]$} \\
\hline \multirow{6}{*}{$\begin{array}{l}\text { Sugarcane } \\
\text { bagasse }\end{array}$} & Lentinula edodes & $130.0-133.0$ & $13.1-13.8$ & $73.0-78.9$ & $0.9-1.0$ & ND & $6.2-7.1$ & [116] \\
\hline & Pleurotus cystidiosus & 49.5 & 22.1 & 45.2 & 2.3 & 22.8 & 7.5 & [109] \\
\hline & Pleurotus djmor & 101.7 & 25.1 & 45.2 & 2.1 & 9.1 & 4.1 & [117] \\
\hline & Pleurotus eryngii & 41.3 & 20.5 & 49.0 & 3.1 & 8.0 & 7.8 & [93] \\
\hline & Pleurotus florida & 75.6 & 8.7 & ND & 4.0 & 2.5 & 0.3 & [118] \\
\hline & Pleurotus ostreatus & 65.7 & 27.1 & 34.9 & 2.0 & 29.3 & 6.7 & [109] \\
\hline Sugarcane straw & Lentinula edodes & $83.0-98.0$ & 14.4 & $72.5-78.2$ & $0.7-0.9$ & NR & $6.4-6.5$ & [116] \\
\hline
\end{tabular}


Table 3. Cont.

\begin{tabular}{|c|c|c|c|c|c|c|c|c|}
\hline \multirow{2}{*}{$\begin{array}{l}\text { Agro-Industrial } \\
\text { Wastes }\end{array}$} & \multirow{2}{*}{ Mushroom Species } & \multirow{2}{*}{$\begin{array}{c}\text { Biological } \\
\text { Efficacy (\%) }\end{array}$} & \multicolumn{5}{|c|}{ Chemical Composition (\% Dry Weight) } & \multirow{2}{*}{ Reference } \\
\hline & & & Crude Protein & Carbohydrate & Fat & Fiber & Ash & \\
\hline \multirow{2}{*}{ Cottonseed hull } & Pleurotus florida & 13.6 & 20.0 & 61.2 & 11.9 & 11.9 & 5.5 & [119] \\
\hline & Pleurotus ostreatus & 8.9 & 17.5 & 65.9 & 1.2 & 10.2 & 5.2 & [119] \\
\hline \multirow{2}{*}{ Cassava peel } & Pleurotus ostreatus & $24.0-26.1$ & $10.5-10.7$ & $73.0-74.6$ & $2.1-2.2$ & $8.5-8.9$ & $7.5-7.7$ & [120] \\
\hline & Volvariella volvacea & $0.6-2.3$ & $11.5-14.3$ & $51.4-53.4$ & $2.4-2.6$ & $0.4-0.5$ & $5.0-6.2$ & [121] \\
\hline $\begin{array}{c}\text { Hardwood } \\
\text { sawdust }\end{array}$ & Hericium erinaceus & $47.5-50.3$ & 24.8 & 60.9 & 3.6 & ND & 10.6 & [87] \\
\hline \multirow{2}{*}{ Acacia sawdust } & Pleurotus cystidiosus & 36.3 & 15.7 & 55.9 & 2.1 & 20.1 & 6.3 & [109] \\
\hline & Pleurotus ostreatus & 46.4 & 19.5 & 51.3 & 1.3 & 22.0 & 5.9 & [109] \\
\hline \multirow{3}{*}{ Beech sawdust } & Agrocybe cylindracea & 38.3 & 18.4 & 70.3 & 3.4 & 15.0 & 8.2 & {$[86]$} \\
\hline & Ganoderma lucidum & 61.2 & 16.8 & 77.9 & 2.2 & 47.9 & 3.1 & [122] \\
\hline & Pleurotus ostreatus & 46.8 & 16.1 & 73.6 & 3.5 & 15.8 & 6.2 & [86] \\
\hline \multirow{3}{*}{ Sawdust } & Auricularia polytricha & $13.9-44.6$ & 10.2 & 78.4 & 0.9 & ND & 4.2 & [123] \\
\hline & Pleurotus columbinus & 89.1 & 1.7 & 25.0 & 0.2 & 4.6 & 9.1 & [91] \\
\hline & Pleurotus citrinopileatus & $38.4-51.6$ & 24.1 & 65.6 & 2.6 & ND & 7.8 & [90] \\
\hline
\end{tabular}

"ND" = not determined. 
Table 4. Biological efficiency and chemical composition of some mushrooms grown on the combination of agro-industrial wastes.

\begin{tabular}{|c|c|c|c|c|c|c|c|c|}
\hline \multirow{2}{*}{ Agro-Industrial Wastes } & \multirow{2}{*}{ Mushroom Species } & \multirow{2}{*}{$\begin{array}{c}\text { Biological } \\
\text { Efficacy }(\%)\end{array}$} & \multicolumn{5}{|c|}{ Chemical Composition (\% Dry Weight) } & \multirow{2}{*}{ Reference } \\
\hline & & & Crude Protein & Carbohydrate & Fat & Fiber & Ash & \\
\hline \multirow{2}{*}{ Soya stalk $(50 \%)+$ rice straw $(50 \%)$} & Pleurotus florida & 85.2 & 22.7 & 54.9 & 2.6 & 7.6 & 6.5 & [111] \\
\hline & Pleurotus ostreatus & 81.7 & 23.0 & 50.5 & 2.7 & 7.7 & 6.4 & [124] \\
\hline \multirow{2}{*}{ Soya stalk $(50 \%)+$ wheat straw $(50 \%)$} & Pleurotus florida & 78.2 & 22.4 & 57.1 & 2.3 & 7.5 & 6.4 & [111] \\
\hline & Pleurotus ostreatus & 77.7 & 21.1 & 52.0 & 2.6 & 7.4 & 6.2 & [124] \\
\hline \multirow{3}{*}{ Wheat straw $(50 \%)+$ Rice straw $(50 \%)$} & Hericium erinaceus & $32.5-37.2$ & 25.6 & 60.6 & 3.9 & ND & 9.7 & [87] \\
\hline & Pleurotus florida & 72.3 & 20.2 & 53.9 & 2.3 & 7.4 & 6.5 & [111] \\
\hline & Pleurotus ostreatus & 71.8 & 20.3 & 56.0 & 2.6 & 7.5 & 5.9 & [124] \\
\hline Oat straw $(80 \%)+$ wheat bran $(20 \%)$ & Ganoderma lucidum & $2.0-2.5$ & $10.6-12.5$ & ND & ND & $47.8-57.7$ & $1.3-1.5$ & [98] \\
\hline \multirow{2}{*}{ Cotton stalk (50\%) + Cottonseed hull (50\%) } & Pleurotus florida & 17.3 & 24.5 & 52.0 & 3.2 & 13.2 & 7.1 & [119] \\
\hline & Pleurotus ostreatus & 20.2 & 22.8 & 58.0 & 2.9 & 10.8 & 5.5 & [119] \\
\hline \multirow{2}{*}{ Acacia sawdust $(50 \%)+\operatorname{corn} \operatorname{cob}(50 \%)$} & Pleurotus cystidiosus & 43.6 & 21.4 & 44.8 & 2.8 & 23.6 & 7.3 & [109] \\
\hline & Pleurotus ostreatus & 58.8 & 18.7 & 46.9 & 3.3 & 24.5 & 6.7 & [109] \\
\hline \multirow{2}{*}{ Acacia sawdust $(50 \%)+$ sugarcane bagasse $(50 \%)$} & Pleurotus cystidiosus & 41.1 & 25.6 & 37.5 & 1.8 & 28.5 & 6.8 & [109] \\
\hline & Pleurotus ostreatus & 58.9 & 24.2 & 37.8 & 2.5 & 28.8 & 6.7 & [109] \\
\hline Sugarcane bagasse $(50 \%)+$ grasses $(50 \%)$ & Agaricus brasiliensis & 44.3 & 28.3 & ND & 1.6 & 5.8 & 6.7 & [125] \\
\hline Rubber tree sawdust $(50 \%)+$ rice straw $(50 \%)$ & Flammulina velutipes & 123.9 & $17.0-27.0$ & $58.0-87.0$ & $1.8-7.3$ & ND & $7.3-10.4$ & [126] \\
\hline Beech sawdust $(50 \%)+$ olive pruning residues $(50 \%)$ & Ganoderma lucidum & 20.5 & 15.3 & 79.3 & 2.0 & 43.8 & 3.4 & [122] \\
\hline Wheat straw $(50 \%)+$ olive pruning residues $(50 \%)$ & Pleurotus ostreatus & 56.8 & 19.9 & 71.7 & 1.9 & 16.5 & 6.5 & [122] \\
\hline Sawdust $(90 \%)+$ rice bran $(10 \%)$ & Pleurotus eous & $48.4-68.1$ & 27.8 & 28.6 & 5.6 & 17.3 & 4.9 & [127] \\
\hline Sugarcane bagasse $(50 \%)+$ rice straw $(50 \%)$ & Lentinus sajor-caju & 83.9 & 30.9 & 33.8 & ND & 24.5 & 6.9 & [128] \\
\hline Cassava peel $(50 \%)+$ corn cobs $(50 \%)$ & Pleurotus ostreatus & $31.1-33.7$ & $10.6-10.8$ & $73.6-74.8$ & $2.1-2.2$ & $8.6-8.9$ & $7.3-7.8$ & [120] \\
\hline Hard wood sawdust $(50 \%)+$ rice straw $(50 \%)$ & Hericium erinaceus & $36.5-44.2$ & 25.1 & 59.8 & 4.0 & ND & 11.0 & [87] \\
\hline Hard wood sawdust $(50 \%)+$ wheat straw $(50 \%)$ & Hericium erinaceus & $41.4-46.5$ & 24.7 & 60.8 & 4.2 & ND & 10.3 & [87] \\
\hline $\begin{array}{c}\text { Hardwood sawdust }(30 \%)+\text { corn stalk }(60 \%) \\
+ \text { rice bran }(10 \%)\end{array}$ & $\begin{array}{l}\text { Auricularia } \\
\text { polytricha }\end{array}$ & $27.3-41.0$ & 11.1 & 76.1 & 0.9 & ND & 4.8 & [129] \\
\hline
\end{tabular}




\section{Lignocellulolytic Enzyme Production by Mushroom Using Agro-Industrial Wastes}

The decomposition of lignocellulosic materials is carried out by decomposers such as bacteria, microfungi, mushrooms, earthworms, and woodlice, all of which play an important role in the terrestrial carbon cycle [130-132]. Lignocellulose is a composite of three main biopolymers: cellulose, hemicellulose and lignin. Due to the different bonding functions that exist among these polymers, lignocellulose degradation requires the synergistic action of multiple carbohydrate-active enzymes. These are involved in the assembly and breakdown of glycosidic bonds [132-134]. The degradation of lignocellulosic biomass is achieved through cooperative activities of hydrolytic and oxidative enzymes [134-136], as is shown in Figure 4. The hydrolytic system is responsible for cellulose and hemicellulose degradations, whereas the oxidative system is known to participate in lignin degradation.

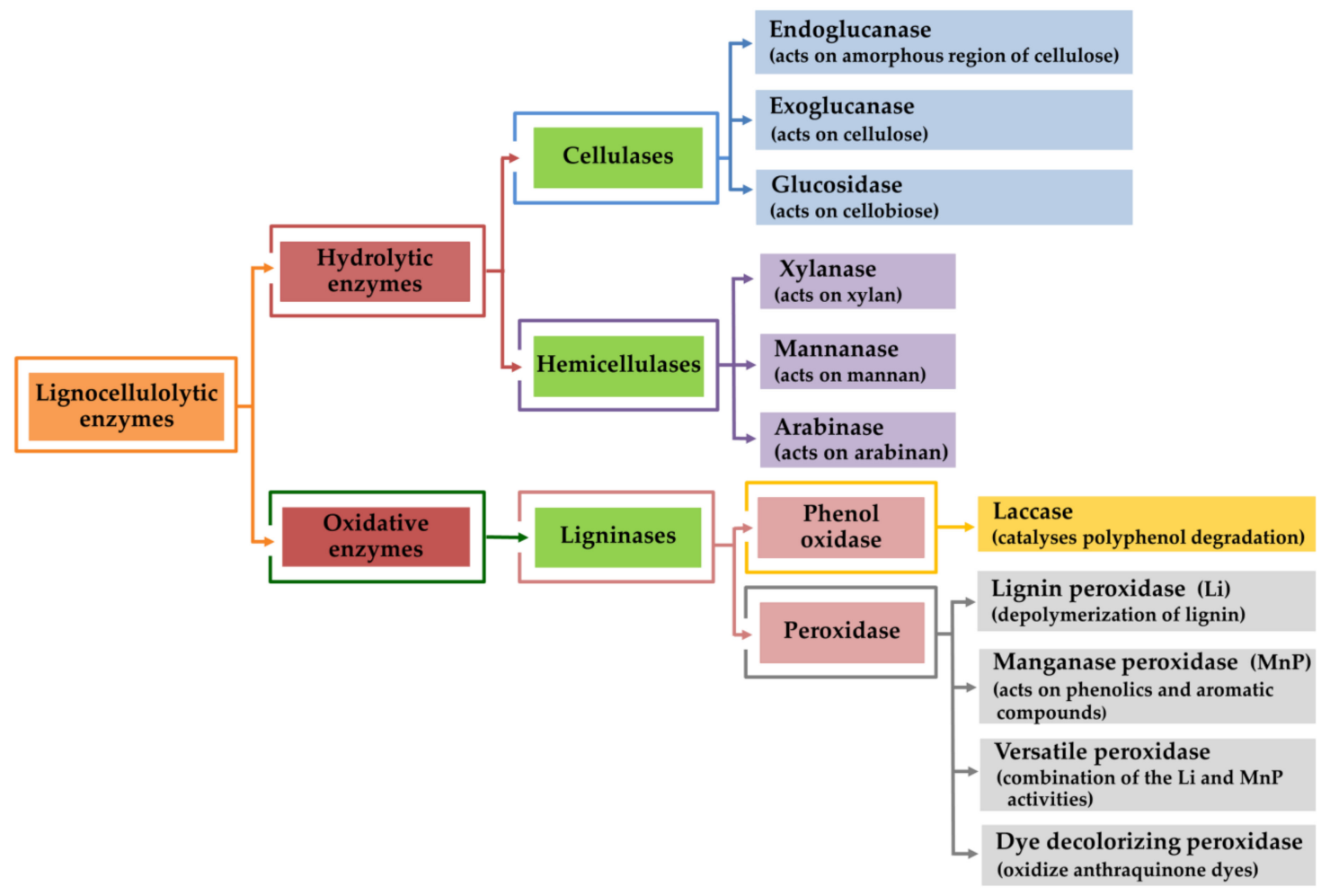

Figure 4. Scheme of the main enzymes involved in the lignocellulosic degradation process.

\subsection{Cellulose Degradation Enzymes}

Commonly, cellulose hydrolysis requires a combination of three main types of cellulase: endo-1,4- $\beta$-D-glucanase (endoglucanase, EC 3.2.1.4), exo-1,4- $\beta$-D-glucanase or cellobiohydrolases (exoglucanase, EC 3.2.1.91) and $\beta$-glucosidase ( $\beta$-D-glucoside glucanhydrolase, EC 3.2.1.21), in order to convert cellulose into oligosaccharides, cellobiose, and glucose $[137,138]$. The degradation of cellulose by various cellulase enzymes is diagrammed in Figure 5. Endoglucanases preferentially hydrolyze internal $\beta-1,4-$ glucosidic linkages in the cellulose chains, generating a number of reducing ends $[138,139]$. This enzyme also acts on cellodextrins, which are the intermediate product of cellulose hydrolysis, and converts them to cellobiose and glucose. Exoglucanases release cellobiose from the reducing end or the nonreducing end of the cellulose chain, facilitating the production of mostly cellobiose which can readily be converted to glucose by $\beta$-glucosidases $[136,140,141]$. These enzymes may also act on cellodextrins and larger cello-oligosaccharides, in which case they are commonly named cellodextrinases [142]. Oligosaccharides released as a result of these activities are converted to glucose by the action of cellodextrinases (EC 3.2.1.74), whereas the cellobiose released mainly by the action of cellobiohydrolases is converted to glucose by $\beta$-glucosidases [139]. 


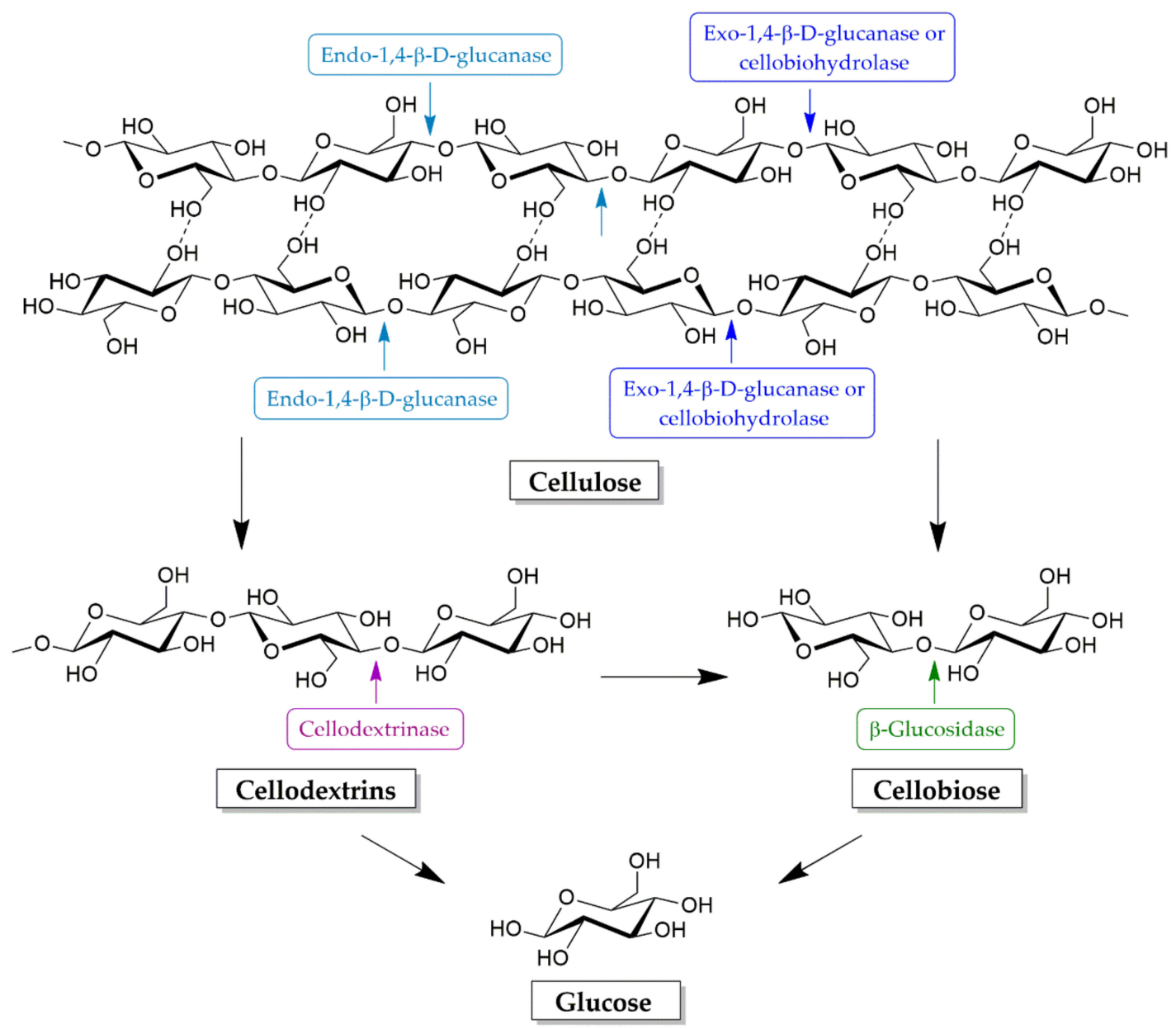

Figure 5. Enzymes involved in cellulose degradation.

Cellulases are produced in a wide range of organisms such as plants, some animals, and certain microorganisms including protozoans, bacteria, and fungi. Among these organisms, fungi have been studied extensively for their cellulase producing capabilities, such as the genera Aspergillus, Penicillium, Rhizopus and Trichoderma [143-146]. However, mushrooms are the most potent degraders of natural lignocellulosic waste. They are mostly grown on litter, dead wood, or in soil and nature-rich cellulose [9]. Several previous reports have found that various mushrooms species can produce cellulase via solid state fermentation (SSF) of agricultural or natural lignocellulosic waste [147-149]. Many agricultural or natural lignocellulosic solid waste, especially different kinds of straw (wheat, sorghum, rice) and sawdust (oak and pine), were used as a substrate or source for mushroom growth and cellulases production [150-153]. Furthermore, other forms of lignocellulosic waste, such as peanut hulls, mandarin peels, cotton waste, corn stovers and tree leaves (Fagus sylvatica), have also been used as substrates to determine cellulase activity $[150,154,155]$. The high-value potential of these forms of waste is encouraging as they can be sources that support the growth and cellulases production of different mushroom species, namely Ganoderma, Grifola, Lentinula, Lentinus, Pleurotus, Piptoporus and Trametes by SSF [152,156-159]. Different agricultural or natural lignocellulosic forms of waste that have been fermented by various mushroom species are summarized in Table 5 . 
Table 5. Production of enzymes in solid state fermentation of cellulose degradation by some mushrooms using agro-industrial wastes.

\begin{tabular}{|c|c|c|c|c|}
\hline Enzyme & $\begin{array}{l}\text { Agro-Industrial } \\
\text { Wastes }\end{array}$ & Mushroom Species & Activity & Reference \\
\hline \multirow{20}{*}{ Total cellulase } & \multirow{5}{*}{ Wheat straw } & Lentinula edodes & $45-60 \mathrm{U} / \mathrm{mL}$ & [151] \\
\hline & & Pleurotus dryinus & $41-120 \mathrm{U} / \mathrm{mL}$ & {$[151,160]$} \\
\hline & & Pleurotus ostreatus & 665-1185 U/mL & [151] \\
\hline & & Pleurotus tuber-regium & $505 \mathrm{U} / \mathrm{mL}$ & [151] \\
\hline & & Fomitopsis sp. & $3.5 \mathrm{U} / \mathrm{gds}$ & [159] \\
\hline & \multirow{4}{*}{$\begin{array}{c}\text { Tree leaves (Fagus } \\
\text { sylvatica) }\end{array}$} & Lentinula edodes & $40-45 \mathrm{U} / \mathrm{mL}$ & [151] \\
\hline & & Pleurotus dryinus & $205 \mathrm{U} / \mathrm{mL}$ & [151] \\
\hline & & Pleurotus ostreatus & $14-15 \mathrm{U} / \mathrm{mL}$ & [151] \\
\hline & & Pleurotus tuber-regium & $20 \mathrm{U} / \mathrm{mL}$ & [151] \\
\hline & \multirow{5}{*}{ Sorghum straw } & Pycnosporus sanguineus & $0.8 \mathrm{U} / \mathrm{gds}$ & [153] \\
\hline & & Pleurotus ostreatus & $1.3 \mathrm{U} / \mathrm{gds}$ & [153] \\
\hline & & Pleurotus eryngii & $0.7 \mathrm{U} / \mathrm{gds}$ & [153] \\
\hline & & Phanerochaete chrysosporium & $1.1 \mathrm{U} / \mathrm{gds}$ & [153] \\
\hline & & Trametes versicolor & $1.0 \mathrm{U} / \mathrm{gds}$ & [153] \\
\hline & \multirow{6}{*}{$\begin{array}{l}\text { Eucalyptus wood } \\
\text { chip }\end{array}$} & Wolfiporia cocos & $1.4-8.3 \mathrm{U} / \mathrm{gds}$ & [161] \\
\hline & & Laetiporeus sulfureus & $0.8-15.4 \mathrm{U} / \mathrm{gds}$ & [161] \\
\hline & & Poria medulla-panis & $0.4-3.4 \mathrm{U} / \mathrm{gds}$ & [161] \\
\hline & & Pycnoporus coccineus & $1.8-3.7 \mathrm{U} / \mathrm{gds}$ & [161] \\
\hline & & Phlebia tremellosa & $0.6-2.0 \mathrm{U} / \mathrm{gds}$ & [161] \\
\hline & & Trametes versicolor & $0.8-4.0 \mathrm{U} / \mathrm{gds}$ & [161] \\
\hline \multirow{27}{*}{ Endoglucanase } & \multirow{6}{*}{ Wheat straw } & Lentinus tigrinus & $1230 \mathrm{U} / \mathrm{gds}$ & [156] \\
\hline & & Lentinula edodes & $180-345 \mathrm{U} / \mathrm{mL}$ & [151] \\
\hline & & Pleurotus dryinus & 910 U/mL & [151] \\
\hline & & Pleurotus ostreatus & $185-245 \mathrm{U} / \mathrm{mL}$ & [151] \\
\hline & & Pleurotus tuber-regium & $150 \mathrm{U} / \mathrm{mL}$ & [151] \\
\hline & & Piptoporus betulinus & $83.5 \mathrm{U} / \mathrm{gds}$ & {$[157]$} \\
\hline & \multirow{4}{*}{$\begin{array}{c}\text { Tree leaves (Fagus } \\
\text { sylvatica) }\end{array}$} & Lentinula edodes & 40-65 U/mL & [151] \\
\hline & & Pleurotus dryinus & $1130 \mathrm{U} / \mathrm{mL}$ & [151] \\
\hline & & Pleurotus ostreatus & 25-1300 U/mL & [151] \\
\hline & & Pleurotus tuber-regium & $150 \mathrm{U} / \mathrm{mL}$ & [151] \\
\hline & \multirow{5}{*}{ Sorghum straw } & Pycnosporus sanguineus & $2.0 \mathrm{U} / \mathrm{gds}$ & [153] \\
\hline & & Pleurotus ostreatus & $2.3 \mathrm{U} / \mathrm{gds}$ & [153] \\
\hline & & Pleurotus eryngii & $1.4 \mathrm{U} / \mathrm{gds}$ & [153] \\
\hline & & Phanerochaete chrysosporium & $4.0 \mathrm{U} / \mathrm{gds}$ & [153] \\
\hline & & Trametes versicolor & $2.2 \mathrm{U} / \mathrm{gds}$ & [153] \\
\hline & \multirow{2}{*}{ Sugarcane bagasse } & Lentinus sajor-caju & $13.9-18.9 \mathrm{U} / \mathrm{gds}$ & [162] \\
\hline & & Pleurotus ostreatus & $3.0 \mathrm{U} / \mathrm{gds}$ & [163] \\
\hline & \multirow{7}{*}{ Sawdust } & Trametes trogii & 504 U/gds & [164] \\
\hline & & Coriolus versicolor & $0.6 \mathrm{U} / \mathrm{gds}$ & [165] \\
\hline & & Ganoderma applanatum & $0.1 \mathrm{U} / \mathrm{gds}$ & [165] \\
\hline & & Pycnoporus sanguineus & $0.6 \mathrm{U} / \mathrm{gds}$ & [165] \\
\hline & & Trametes villosa & $0.2 \mathrm{U} / \mathrm{gds}$ & [165] \\
\hline & & Pleurotus ostreatus & $3.0 \mathrm{U} / \mathrm{gds}$ & [163] \\
\hline & & Lentinus sajor-caju & $0.9 \mathrm{U} / \mathrm{gds}$ & [163] \\
\hline & \multirow{2}{*}{ Rice straw } & Pleurotus ostreatus & $7.1 \mathrm{U} / \mathrm{gds}$ & [163] \\
\hline & & Lentinus sajor-caju & $1.9 \mathrm{U} / \mathrm{gds}$ & [163] \\
\hline & Oak sawdust & Grifola frondosa & $12.3 \mathrm{U} / \mathrm{gds}$ & [152] \\
\hline
\end{tabular}


Table 5. Cont.

\begin{tabular}{|c|c|c|c|c|}
\hline Enzyme & $\begin{array}{l}\text { Agro-Industrial } \\
\text { Wastes }\end{array}$ & Mushroom Species & Activity & Reference \\
\hline \multirow{6}{*}{ Endoglucanase } & \multirow{4}{*}{ Pine chip } & Coriolus versicolor & $2.4 \mathrm{U} / \mathrm{gds}$ & [165] \\
\hline & & Ganoderma applanatum & $2.8 \mathrm{U} / \mathrm{gds}$ & [165] \\
\hline & & Pycnoporus sanguineus & $4.8 \mathrm{U} / \mathrm{gds}$ & [165] \\
\hline & & Trametes villosa & $3.9 \mathrm{U} / \mathrm{gds}$ & [165] \\
\hline & Green tea waste & Microporus xanthopus & $38.6 \mathrm{U} / \mathrm{gds}$ & [166] \\
\hline & Wheat straw & Fomitopsis sp. & $53.6 \mathrm{U} / \mathrm{gds}$ & [159] \\
\hline \multirow{8}{*}{ Exoglucanase } & Oak sawdust & Grifola frondosa & $16.2 \mathrm{U} / \mathrm{gds}$ & [152] \\
\hline & \multirow{2}{*}{ Rice straw } & Pleurotus ostreatus & $2.0 \mathrm{U} / \mathrm{gds}$ & [163] \\
\hline & & Lentinus sajor-caju & $1.8 \mathrm{U} / \mathrm{gds}$ & [163] \\
\hline & \multirow{2}{*}{ Sugarcane bagasse } & Pleurotus ostreatus & $7.0 \mathrm{U} / \mathrm{gds}$ & [163] \\
\hline & & Lentinus sajor-caju & $2.0 \mathrm{U} / \mathrm{gds}$ & [163] \\
\hline & \multirow{2}{*}{ Sawdust } & Pleurotus ostreatus & $2.8 \mathrm{U} / \mathrm{gds}$ & [163] \\
\hline & & Lentinus sajor-caju & $0.6 \mathrm{U} / \mathrm{gds}$ & [163] \\
\hline & Corn stover & Irpex lacteus & $69.3 \mathrm{U} / \mathrm{gds}$ & [167] \\
\hline \multirow{31}{*}{$\beta$-Glucosidase } & \multirow{5}{*}{ Sorghum straw } & Pycnosporus sanguineus & $0.4 \mathrm{U} / \mathrm{gds}$ & [153] \\
\hline & & Pleurotus ostreatus & $0.2 \mathrm{U} / \mathrm{gds}$ & [153] \\
\hline & & Pleurotus eryngii & $0.2 \mathrm{U} / \mathrm{gds}$ & [153] \\
\hline & & Phanerochaete chrysosporium & $1.1 \mathrm{U} / \mathrm{gds}$ & [153] \\
\hline & & Trametes versicolor & $1.9 \mathrm{U} / \mathrm{gds}$ & [153] \\
\hline & \multirow{6}{*}{$\begin{array}{l}\text { Eucalyptus wood } \\
\text { chip }\end{array}$} & Wolfiporia cocos & 8.3-42.0 U/gds & [161] \\
\hline & & Laetiporeus sulfureus & 7.6-37 U/gds & [161] \\
\hline & & Poria medulla-panis & $2.7-10.5 \mathrm{U} / \mathrm{gds}$ & [161] \\
\hline & & Pycnoporus coccineus & $8.0-22.0 \mathrm{U} / \mathrm{gds}$ & [161] \\
\hline & & Phlebia tremellosa & $3.8-15.6 \mathrm{U} / \mathrm{gds}$ & [161] \\
\hline & & Trametes versicolor & $3.8-20.0 \mathrm{U} / \mathrm{gds}$ & [161] \\
\hline & Oak sawdust & Grifola frondosa & $2.3 \mathrm{U} / \mathrm{gds}$ & [152] \\
\hline & \multirow{2}{*}{ Rice straw } & Pleurotus ostreatus & $2.5 \mathrm{U} / \mathrm{gds}$ & [163] \\
\hline & & Lentinus sajor-caju & $1.2 \mathrm{U} / \mathrm{gds}$ & [163] \\
\hline & \multirow{2}{*}{ Sugarcane bagasse } & Pleurotus ostreatus & $3.5 \mathrm{U} / \mathrm{gds}$ & [163] \\
\hline & & Lentinus sajor-caju & 2.6-12.3 U/gds & {$[162,163]$} \\
\hline & \multirow{7}{*}{ Sawdust } & Pleurotus ostreatus & $2.2 \mathrm{U} / \mathrm{gds}$ & [163] \\
\hline & & Lentinus sajor-caju & $0.2 \mathrm{U} / \mathrm{gds}$ & [163] \\
\hline & & Coriolus versicolor & $0.5 \mathrm{U} / \mathrm{gds}$ & [165] \\
\hline & & Ganoderma applanatum & $0.4 \mathrm{U} / \mathrm{gds}$ & [165] \\
\hline & & Pycnoporus sanguineus & $0.4 \mathrm{U} / \mathrm{gds}$ & [165] \\
\hline & & Trametes villosa & $0.5 \mathrm{U} / \mathrm{gds}$ & [165] \\
\hline & & Trametes trogii & $0.89 \mathrm{U} / \mathrm{gds}$ & [164] \\
\hline & \multirow{4}{*}{ Pine chip } & Coriolus versicolor & $0.3 \mathrm{U} / \mathrm{gds}$ & [165] \\
\hline & & Ganoderma applanatum & $0.1 \mathrm{U} / \mathrm{gds}$ & [165] \\
\hline & & Pycnoporus sanguineus & $0.8 \mathrm{U} / \mathrm{gds}$ & [165] \\
\hline & & Trametes villosa & $0.5 \mathrm{U} / \mathrm{gds}$ & [165] \\
\hline & \multirow{3}{*}{ Wheat straw } & Piptoporus betulinus & $78.8 \mathrm{U} / \mathrm{gds}$ & [157] \\
\hline & & Pleurotus dryinus & $401 \mathrm{U} / \mathrm{gds}$ & [160] \\
\hline & & Lentinula edodes & $0.1 \mathrm{U} / \mathrm{gds}$ & [168] \\
\hline & Sorghum straw & Pleurotus eryngii & $0.23 \mathrm{U} / \mathrm{gds}$ & [153] \\
\hline
\end{tabular}

Cellulase activity is mainly tested using a reducing sugar assay to determine cellulase hydrolysis activity at the end of the production process [169]. The common enzyme activity assays consist of 
total cellulase assays, endoglucanase assays, exoglucanase assays and $\beta$-glucosidase assays [140]. Filter paper assay (FPA) is widely used to determine total cellulase activity. The degree of filter paper activity is determined as the micromole of glucose equivalent liberated per minute of culture filtrate under assay conditions [170]. Endoglucanase activity can be measured using the carboxymethyl cellulose (CMC) as a substrate. This carboxymethyl cellulase (CMCase) is mainly measured by examining the reducing sugars of enzymatic reactions with $\mathrm{CMC}$ based on the procedure described by [171]. The exoglucanase activity mainly uses commercial Avicel as a substrate for measuring the activity [169]. The $\beta$-glucosidase assay can be measured based on the procedure of Kubicek [172] using chromogenic and nonchromogenic substrates such as $p$-nitrophenol- $\beta$-glucoside (pNPG) and cellobiose, respectively [173,174]. Moreover, various reducing sugar assays, for instance, 3,5-dinitrosalicylic acid (DNS), glucose oxidase (GOD) and high-performance liquid chromatography were also used.

\subsection{Hemicellulose Degradation Enzymes}

Hemicelluloses are usually classified based on the backbone sugars present in the structural polymer with typical glucose galactose, xylose, mannose, and arabinose. The principal hemicelluloses are comprised of xyloglucans, xylans, mannans, glucomannans, and mixed linkage $\beta$-glucans $[175,176]$. In order to digest hemicellulose, microorganisms need to be able to produce a variety of enzymes to hydrolyze complex substrates with a synergistic action. Hemicellulolytic enzymes or hemicellulases are glycoside hydrolases or carbohydrate esterases that are responsible for polysaccharide degradation. The enzymes include xylanase (EC 3.2.1.8), $\beta$-xylosidase (EC 3.2.1.37), $\alpha$-arabinofuranosidase (EC 3.2.1.55) $\alpha$-glucuronidase (EC 3.2.1.139), and $\beta$-mannosidases (EC 3.2.1.25) [134,138].

\subsubsection{Xylanases}

Xylan is a heteropolysaccharide and a major hemicellulose. The main chain of xylan consists of $\beta$-1,4-linked D-xylopyranosyl residues, which are partially replaced with $O$-acetyl, L-arabinosyl and 4-O-methyl-D-glucuronic acid. The xylan backbone is substituted by different side chains with L-arabinose, D-galactose, D-mannoses, and glucouronic acid linked by glysosidic bonds and ester bonds with ferulic acid [177-180]. Biodegradation of xylan requires diverse modes of action of hydrolytic enzymes. Xylanases are a group of glycoside hydrolase enzymes that breakdown hemicelluloses through the degradation of the linear polysaccharide xylan into xylose by catalyzing the hydrolysis of the glycosidic linkage $(\beta-1,4)$ of xylosides. The xylanolytic enzyme system includes a mixture of endo- $1,4-\beta$-xylanases also called endo-xylanases, $\beta$-xylosidases, $\alpha$-arabino-furanosidases, $\alpha$-glucuronidases and acetylxylanases, which attach to the specific site of xylan as is displayed in

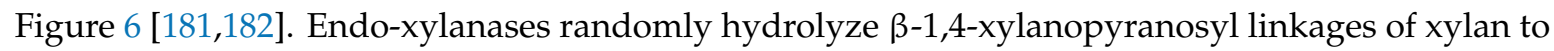
form xylo-oligosaccharides, xylotriose, xylobiose and xylose. The hydrolysis of xylans is not attacked randomly but depends upon the degree of branching, chain length, and presence of substituents in the substrate molecule [183].

$\beta$-Xylosidase attacks from the non-reducing end of xylo-oligosaccharides, xylotriose or xylobiose, that are generated by the action of endo-xylanase and ultimately liberate xylose sugar (Figure 6). Biomass can be used as a substrate for this enzyme production process. However, a limitation of the commercial application of this substance is related to various factors such as their physical limitations, the limited hydrolysis of xylans due to their diverged branched nature, the fact that their enzymes are associated with a narrow $\mathrm{pH}$ range and thermal instability, their end product inhibition levels and the cost of enzyme production. These comprise the unreachability of substrates to xylanase enzymes [178]. The use of substrates with agricultural or industrial biomass for enzyme production serves as an alternative way to overcome the limitations of the costs of enzyme production; however, biomass pretreatment is sometimes needed to improve efficiency in the practical hydrolysis of biomass. 


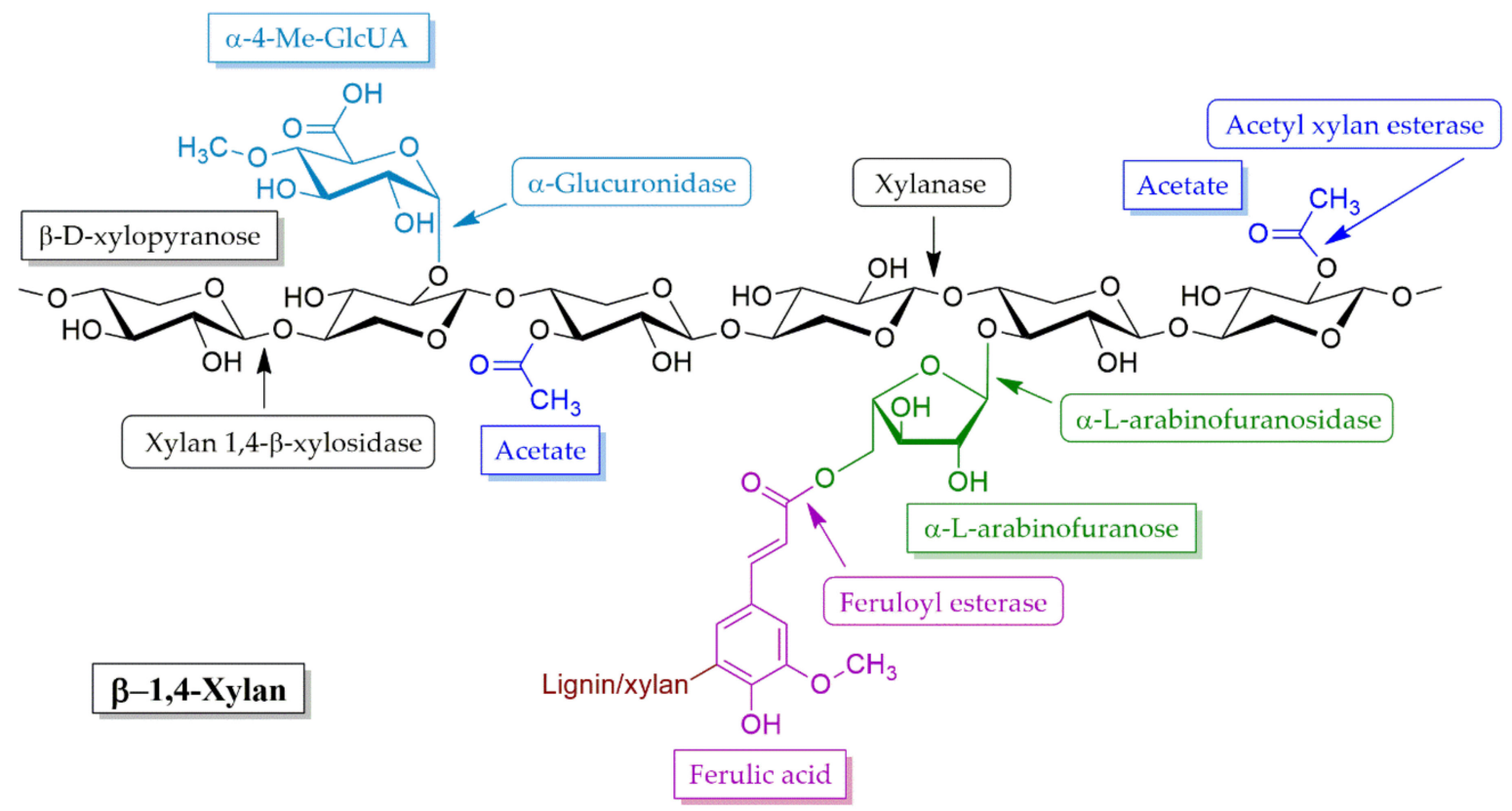

Figure 6. Enzymes involved in xylan degradation.

Many microorganisms, such as fungi, bacteria and yeast, can degrade hemicellulose by producing xylanases. A determination of xylanase activities can be analyzed by several methods. The plate assay has been used for decades as a primary screening method to select xylanase producing strains. The screening strains are cultured on agar medium containing xylan as their carbon source until clear zones are observed (the xylan hydrolysis area) after being stained with Congo red dye [183] or Gram's iodine solution [184]. Plate assay methods rely on interactions between a dye and a polymeric substrate for the indirect detection of hydrolysis but require the use of relevant controls and independent confirmation of the relevant enzymatic activities. Xylans, such as oat spelt, beech wood [185], and birch-wood xylans [186,187], was used as a substrate to determine endo-xylanase activity. The enzyme activities were determined from the presence of reducing sugars as xylose equivalents liberated from the enzymatic hydrolysis by the DNS method [188] or the Nelson [189] and Somogyi [190] methods. However, xylans obtained from natural sources contain not only xylose residues but also arabinose and glucuronic acid residues. Thus, comparisons of xylanase activity in various studies have been difficult. Xylanase activity varies according to the source of the xylans. Other types of substrates can be applied. Specifically, $p$-nitrophenyl-glycoside substrate ( $p$-nitrophenyl esters with substrate) can be used as a chromogenic substrate for the calorimetric assay of $\beta$-xylosidase activity. The substrate is colorless in neutral or alkaline solution. After enzymatic hydrolysis, $p$-nitrophenol is liberated as alkaline $\mathrm{pH}$ develops a yellow color that is suitable for the quantitative measurement of the enzyme activity.

Multifunctional xylanolytic enzyme system is relatively common in fungi, actinomycetes and bacteria [190,191]. A large variety of industrial xylanase enzymes are produced from various kind of microorganisms [192]. SSF with batch processing has been used for the utilization of agro-industrial waste [193]. However, very few studies have reported on the xylanolytic enzymes obtained from mushroom on SSF (Table 6). These potential outcomes provide opportunities for scientists to explore the hydrolytic potential of xylanase for the efficient saccharifcation of lignocellulosic biomass from mushroom cultivation.

\subsubsection{Mananases}

The two most important and representative hemicelluloses are xylans and mannans. Mannans are polysaccharides that consist of mannose-based backbones linked by $\beta-1,4-$ linkage with variable degrees of side substitutions. These polysaccharides are renewable resources and their enzymatic conversion 
is of great interest in the field of lignocellulose biotechnology [194]. The enzyme breakdown of mannans is accomplished with $\beta$-mannanase ( $\beta-1,4-\mathrm{D}$-mannan mannohydrolase, EC 3.2.1.78) as it randomly attacks the internal $\beta$-1,4-D-mannopyranosyl linkage within the main chain of various mannan-based polysaccharides, such as galactomannans, glucomannans, and galactoglucomannans, to release mannooligosaccharides (MOS), manotetrose, manotriose and manobiose [176].

The degradation of the mannan backbone is performed by the action of $\beta$-mannanases, and the further degradation requires $\beta$-mannosidase ( $\beta$-1,4-D-mannopyranoside hydrolase, EC 3.2.1.25) to hydrolyze the terminal ends (non-reducing ends) of MOS into sugar-based mannose. Subsequently, $\beta$-glucosidases remove 1,4-glucopyranose units at the non-reducing ends of the oligomers derived from the degradation of glucomannan and galactoglucomannan $[171,205]$ as is shown in Figure 7. Xylanases and mannanases are important enzymes for the hydrolysis of hemicelluloses. $\beta$-mannan is found in many feedstuffs including soybean meal, palm kernel meal, copra meal, and sesame meal and other leguminous feeds [206]. $\beta$-Mannanases are widely applied to randomly hydrolyze the $\beta-1,4$-mannopyranoside linkage of mannan-based polysaccharides in many industries.
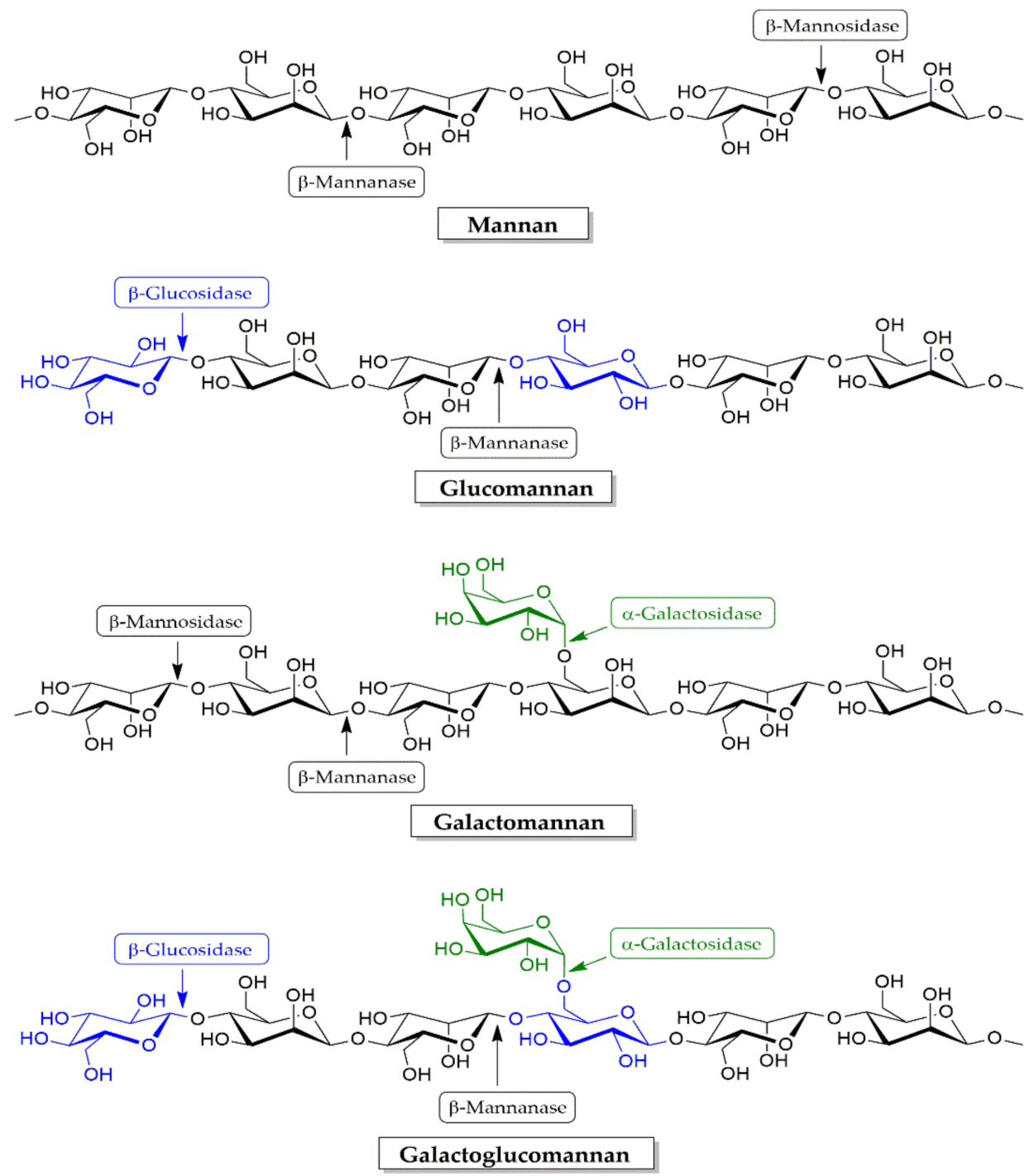

Figure 7. Enzymes involved in mannan degradation. 
Table 6. Production of enzymes in solid state fermentation of hemicellulose degradation by some mushrooms using agro-industrial wastes.

\begin{tabular}{|c|c|c|c|c|}
\hline Enzyme & Agro-Industrial Wastes & Mushroom Species & Activity & Reference \\
\hline \multirow{16}{*}{ Total xylanase } & \multirow{4}{*}{$\begin{array}{c}\text { Tree leaves } \\
\text { (Fagus sylvatica) }\end{array}$} & Lentinula edodes & 85-200 U/mL & [151] \\
\hline & & Pleurotus dryinus & $2145 \mathrm{U} / \mathrm{mL}$ & [151] \\
\hline & & Pleurotus ostreatus & $160-1400 \mathrm{U} / \mathrm{mL}$ & [151] \\
\hline & & Pleurotus tuber-regium & $155 \mathrm{U} / \mathrm{mL}$ & [151] \\
\hline & \multirow{4}{*}{ Wheat straw } & Lentinula edodes & $195-275 \mathrm{U} / \mathrm{mL}$ & [151] \\
\hline & & Pleurotus dryinus & $1450 \mathrm{U} / \mathrm{mL}$ & [151] \\
\hline & & Pleurotus ostreatus & $260-735 \mathrm{U} / \mathrm{mL}$ & [151] \\
\hline & & Pleurotus tuber-regium & $260 \mathrm{U} / \mathrm{mL}$ & [151] \\
\hline & \multirow{8}{*}{ Wheat bran } & Fomes fomentarius & 7-63 U/mL & [154] \\
\hline & & Ganoderma applanatum & $3 \mathrm{U} / \mathrm{mL}$ & [154] \\
\hline & & Pleurotus ostreatus & $16 \mathrm{U} / \mathrm{mL}$ & [154] \\
\hline & & Trametes hirsuta & $8 \mathrm{U} / \mathrm{mL}$ & [154] \\
\hline & & Trametes ochracea & $35 \mathrm{U} / \mathrm{mL}$ & [154] \\
\hline & & Trametes versicolor & $21 \mathrm{U} / \mathrm{mL}$ & [154] \\
\hline & & Trametes pubescens & $32 \mathrm{U} / \mathrm{mL}$ & [154] \\
\hline & & Trametes biforme & $19 \mathrm{U} / \mathrm{mL}$ & [154] \\
\hline \multirow{18}{*}{ Endo- $1,4-\beta$-xylanase } & Rice straw & Pleurotus ostreatus & $21 \mathrm{U} / \mathrm{gds}$ & [195] \\
\hline & Sawdust & Pleurotus ostreatus & $9 \mathrm{U} / \mathrm{gds}$ & [195] \\
\hline & Sugarcane bagasse & Ganoderma lucidum & $33 \mathrm{U} / \mathrm{gds}$ & [196] \\
\hline & \multirow{2}{*}{ Tomato pomace } & Pleurotus ostreatus & $9 \mathrm{U} / \mathrm{gds}$ & [197] \\
\hline & & Trametes versicolor & $50 \mathrm{U} / \mathrm{gds}$ & [197] \\
\hline & Jerusalem artichoke stalk & Schizophyllum commune & $106 \mathrm{U} / \mathrm{gds}$ & [198] \\
\hline & \multirow{3}{*}{ Oak leaves } & Marasmius quercophilus & $73 \mathrm{U} / \mathrm{gds}$ & [199] \\
\hline & & Mycena inclinata & $105 \mathrm{U} / \mathrm{gds}$ & [199] \\
\hline & & Pholiota lenta & $83.2 \mathrm{U} / \mathrm{gds}$ & [199] \\
\hline & \multirow{2}{*}{ Wheat straw } & Pleurotus citrinopileatus & $0.12 \mathrm{U} / \mathrm{gds}$ & [200] \\
\hline & & Pleurotus ostreatus & $0.14 \mathrm{U} / \mathrm{gds}$ & [200] \\
\hline & Pine wood chip & $\begin{array}{l}\text { Ceriporiopsis } \\
\text { subvermispora }\end{array}$ & $0.25 \mathrm{U} / \mathrm{gds}$ & [201] \\
\hline & Eucalyptus wood chip & $\begin{array}{l}\text { Ceriporiopsis } \\
\text { subvermispora }\end{array}$ & $0.12 \mathrm{U} / \mathrm{gds}$ & [201] \\
\hline & Soya bran & Fomes sclerodermeus & $31 \mathrm{U} / \mathrm{gds}$ & [202] \\
\hline & Rice bran mixed rice husk & Leucoagaricus meleagris & $0.8 \mathrm{U} / \mathrm{gds}$ & [203] \\
\hline & \multirow{3}{*}{$\begin{array}{l}\text { Sugarcane bagasse } \\
\text { mixed wheat bran }\end{array}$} & Pleurotus ostreatus & $8.7 \mathrm{U} / \mathrm{gds}$ & [204] \\
\hline & & Ganoderma lucidum & $16.3 \mathrm{U} / \mathrm{gds}$ & [204] \\
\hline & & Trametes versicolor & $36.7 \mathrm{U} / \mathrm{gds}$ & [204] \\
\hline \multirow{9}{*}{$1,4-\beta-X y l o s i d a s e$} & \multirow{3}{*}{ Oak leaves } & Marasmius quercophilus & $1.7 \mathrm{U} / \mathrm{gds}$ & [199] \\
\hline & & Mycena inclinata & $5.8 \mathrm{U} / \mathrm{gds}$ & [199] \\
\hline & & Pholiota lenta & $1.6 \mathrm{U} / \mathrm{gds}$ & [199] \\
\hline & Pine wood chip & $\begin{array}{l}\text { Ceriporiopsis } \\
\text { subvermispora }\end{array}$ & $4.4 \mathrm{U} / \mathrm{gds}$ & [201] \\
\hline & Eucalyptus wood chip & $\begin{array}{l}\text { Ceriporiopsis } \\
\text { subvermispora }\end{array}$ & $2.6 \mathrm{U} / \mathrm{gds}$ & [201] \\
\hline & \multirow{2}{*}{ Wheat straw } & Pleurotus citrinopileatus & $11.5 \mathrm{U} / \mathrm{gds}$ & [200] \\
\hline & & Pleurotus ostreatus & $14.3 \mathrm{U} / \mathrm{gds}$ & [200] \\
\hline & \multirow{2}{*}{$\begin{array}{l}\text { Sugarcane bagasse mixed wheat } \\
\text { bran }\end{array}$} & Ganoderma lucidum & $0.4 \mathrm{U} / \mathrm{gds}$ & [204] \\
\hline & & Trametes versicolor & $1.5 \mathrm{U} / \mathrm{gds}$ & [204] \\
\hline
\end{tabular}


Table 6. Cont

\begin{tabular}{|c|c|c|c|c|}
\hline Enzyme & Agro-Industrial Wastes & Mushroom Species & Activity & Reference \\
\hline \multirow{5}{*}{ Endo-1,4- $\beta$-mannanase } & \multirow{3}{*}{ Oak leaves } & Marasmius quercophilus & $3.4 \mathrm{U} / \mathrm{gds}$ & [199] \\
\hline & & Mycena inclinata & $3.2 \mathrm{U} / \mathrm{gds}$ & [199] \\
\hline & & Pholiota lenta & $11.8 \mathrm{U} / \mathrm{gds}$ & [199] \\
\hline & Pine wood chip & $\begin{array}{l}\text { Ceriporiopsis } \\
\text { subvermispora }\end{array}$ & $90.4 \mathrm{U} / \mathrm{gds}$ & [201] \\
\hline & Eucalyptus wood chip & $\begin{array}{l}\text { Ceriporiopsis } \\
\text { subvermispora }\end{array}$ & $52.2 \mathrm{U} / \mathrm{gds}$ & [201] \\
\hline \multirow{2}{*}{ 1,4- $\beta$-Mannosidase } & \multirow{2}{*}{ Oak leaves } & Marasmius quercophilus & $5.9 \mathrm{U} / \mathrm{gds}$ & [199] \\
\hline & & Mycena inclinata & $4.2 \mathrm{U} / \mathrm{gds}$ & [199] \\
\hline
\end{tabular}

\subsubsection{Arabinanases}

Arabinanases are a group of hydrolytic enzymes that include endo-arabinanases (EC 3.2.1.99), arabinosidases (EC 3.2.1.55), and $\alpha$-L-arabinofuranosidase. These work synergistically to generate L-arabinose from arabinan as is shown in Figure 8 [207-211]. The biodegradation of xylan requires the cooperation of xylanases, $\beta$-xylosidase, $\alpha$-L-arabinofuranosidase, $\alpha$-glucuronidase, and acetylxylanases [181,182]. The removal of the side groups of xylans is catalyzed by $\alpha$-L-arabinofuranosidases (E.C. 3.2.1.55), $\alpha$-D-glucuronidases and acetylxylan esterases, which remove acetyl and phenolic side branches and act synergistically on the complex polymer [178]. Fungi produce extracellular arabinanases, a group of hydrolytic enzymes that include $\alpha$-L-arabinofuranosidases and endo-arabinanases to specifically release L-arabinose from polysaccharides including xylans and pectin [212]. Importantly, $\alpha$-L-arabinofuranosidases catalyze the hydrolysis of $\alpha$-L-arabinofuranosidic linkage at terminal non-reducing- $\alpha$-L-1,2-, $\alpha$-L-1,3- and $\alpha-\mathrm{L}-1,5$-arabinofuranosyl residues obtained from different oligosaccharides and polysaccharides ( $\alpha$-L-arabinosides, arabinans, arabinoxylans, and arabinogalactans) and act synergistically with other hemicellulases to completely breakdown hemicellulose $[212,213]$. The L-arabinofuranoside substitutions on xylan strongly inhibit the action of xylan-degrading enzymes, thus preventing the complete degradation of xylan to xylose units [213]. The $\alpha$-L-arabinofuranosidases can be found in plants, bacteria and fungi [186].

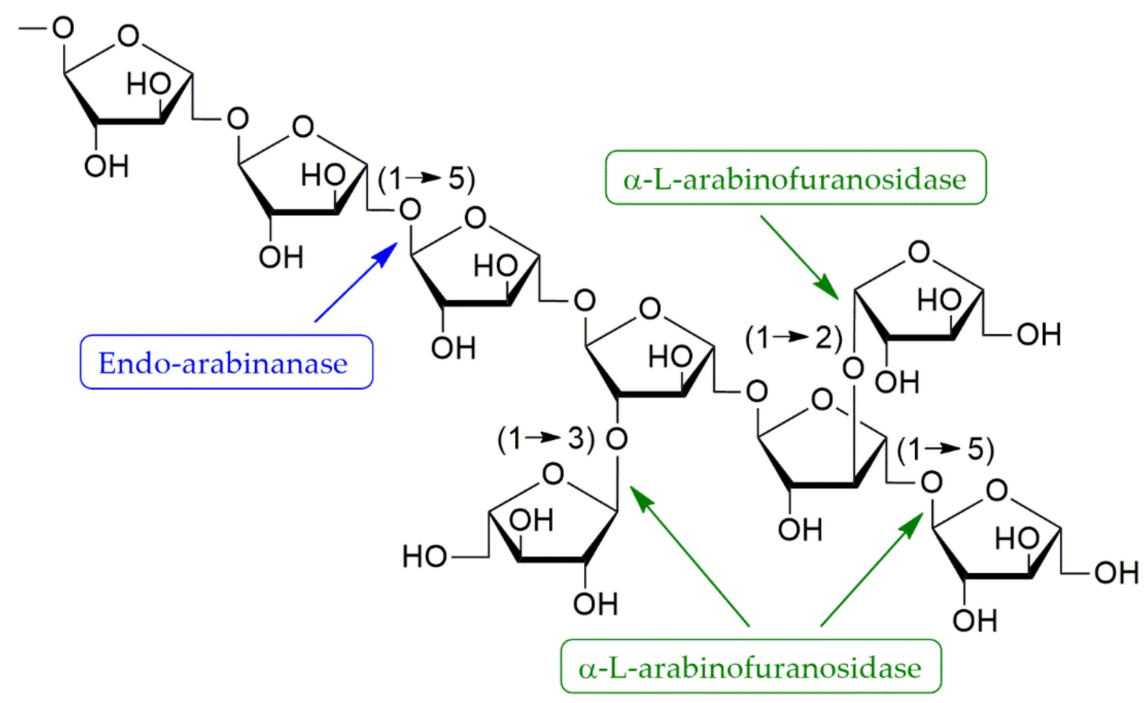

\section{Arabinan}

Figure 8. Enzymes involved in arabinan degradation. 
The colorimetric method is used to determine $\alpha$-L-arabinofuranosidases activity. Notably, the $p$-nitrophenol-linked substrate, 4-nitrophenyl $\alpha$-L-arabinofuranoside, is used for the enzyme assay by determining the amount of $p$-nitrophenol released from the enzyme-substrate reaction $[186,214,215]$. Arabinoxylans, such as wheat four arabinoxylan and sugar beet arabinan, is also used for the determination of enzyme activity [180] by monitoring the generation of arabinose from polysaccharide substrates. Liberated arabinose can be determined by the DNS method [187].

\subsection{Lignin Degradation Enzymes}

Lignin degradation is the primordial step in lignocellulose degradation enabling the accessibility of cellulose and hemicellulose [216,217]. Ligninolytic microorganisms can degrade lignins via the secretion of oxidative enzymes, such as peroxidases and laccases, or by producing a source of heterogeneous aromatics. Ligninolytic enzymes or ligninases are mainly comprised of laccases (Lac, EC 1.10.3.2), lignin peroxidases (LiPs, EC 1.11.1.14), manganese peroxidases (MnPs, EC 1.11.1.13), versatile peroxidases (VPs) and dye decolorizing peroxidases (DyPs, EC 1.11.1.19) [116,218]. These enzymes display less substrate specificity than cellulases and hemicellulases [124,218,219]. Additionally, Lac, LiP and MnP, and many other enzymes, such as aromatic acid reductase, aryl alcohol dehydrogenase, catalase aromatic aldehyde oxidase, dioxygenase, quinone oxidoreductase, vanillate hydroxylase, veratryl alcohol oxidase and versatile peroxidase, are also involved in lignin digestion [219].

Mushroom species are most frequently reported as Lac and MnP producers and least frequently reported as LiP and VP producers. Previous publications have reported that T. versicolor [220] and Bjerkandera adusta [221] produce both oxidase (Lac) and peroxidase (MnP and LiP). Lentinula edodes [222], P. eryngii [223] and Ceripotiopsis subvermispora [224] are lignin-degrading mushrooms that use Lac and at least one of the peroxidases. Only Lac was produced from S. commune and only peroxidases were produced from Phanerochaete chrysosporium [225,226]. Several publications have reported that Ph. chrysosporium is an excellent lignin decomposer, and it has been suggested for its commercial use. The ligninolytic enzymes were fermented in SSF using different agro-industrial waste, as is shown in Table 7 .

Table 7. Production of enzymes in solid state fermentation of lignin degradation by some mushrooms using agro-industrial wastes.

\begin{tabular}{|c|c|c|c|c|}
\hline Enzyme & Agro-Industrial Wastes & Mushroom Species & Activity & Reference \\
\hline \multirow{18}{*}{ Laccase } & \multirow{4}{*}{ Tree leaves (Fagus sylvatica) } & Lentinula edodes & $7-52 \mathrm{U} / \mathrm{L}$ & [151] \\
\hline & & Pleurotus dryinus & $16 \mathrm{U} / \mathrm{L}$ & [151] \\
\hline & & Pleurotus ostreatus & $6.3-8.0 \mathrm{U} / \mathrm{L}$ & [151] \\
\hline & & Pleurotus tuber-regium & $2.1 \mathrm{U} / \mathrm{L}$ & [151] \\
\hline & \multirow{5}{*}{ Wheat straw } & Lentinula edodes & $3.6-5.2 \mathrm{U} / \mathrm{L}$ & [151] \\
\hline & & Pleurotus dryinus & $5.7 \mathrm{U} / \mathrm{L}$ & [151] \\
\hline & & Pleurotus ostreatus & $1.1-10.1 \mathrm{U} / \mathrm{L}$ & [151] \\
\hline & & Pleurotus tuber-regium & $10 \mathrm{U} / \mathrm{L}$ & [151] \\
\hline & & Pleurotus citrinopileatus & $1.2-3.7 \mathrm{U} / \mathrm{gds}$ & [200] \\
\hline & \multirow{8}{*}{ Wheat bran } & Fomes fomentarius & $7430-17510 \mathrm{U} / \mathrm{L}$ & [154] \\
\hline & & Ganoderma applanatum & $1910 \mathrm{U} / \mathrm{L}$ & [154] \\
\hline & & Pleurotus ostreatus & $9210 \mathrm{U} / \mathrm{L}$ & [154] \\
\hline & & Trametes hirsuta & $7350 \mathrm{U} / \mathrm{L}$ & [154] \\
\hline & & Trametes ochracea & $3930 \mathrm{U} / \mathrm{L}$ & [154] \\
\hline & & Trametes versicolor & $17860 \mathrm{U} / \mathrm{L}$ & [154] \\
\hline & & Trametes pubescens & $5319 \mathrm{U} / \mathrm{L}$ & [154] \\
\hline & & Trametes biforme & $4960 \mathrm{U} / \mathrm{L}$ & [154] \\
\hline & Wheat bran mixed corn straw & Trametes versicolor & $32.1 \mathrm{U} / \mathrm{gds}$ & [227] \\
\hline
\end{tabular}


Table 7. Cont.

\begin{tabular}{|c|c|c|c|c|}
\hline Enzyme & Agro-Industrial Wastes & Mushroom Species & Activity & Reference \\
\hline \multirow{11}{*}{ Laccase } & Corn stalk & Trametes versicolor & $2,765.81 \mathrm{U} / \mathrm{L}$ & [228] \\
\hline & Sawdust & Coriolopsis gallica & $200 \mathrm{U} / \mathrm{gds}$ & [229] \\
\hline & Sugarcane bagasse & Pleurotus ostreatus & $151.6 \mathrm{U} / \mathrm{gds}$ & [230] \\
\hline & Oat husk & Cerrena unicolor & $28.2 \mathrm{U} / \mathrm{gds}$ & [231] \\
\hline & Pineapple leaves & Ganoderma lucidum & $42.7 \mathrm{U} / \mathrm{gds}$ & [232] \\
\hline & Rice bran mixed wheat bran & Stereum ostrea & $24962 \mathrm{U} / \mathrm{L}$ & [233] \\
\hline & Rice straw & Schizophyllum commune & $431.2 \mathrm{U} / \mathrm{gsd}$ & [234] \\
\hline & Sugarcane bagasse mixed & Ganoderma lucidum & $9.4 \mathrm{U} / \mathrm{gds}$ & [204] \\
\hline & wheat bran & Pleurotus ostreatus & $2.1 \mathrm{U} / \mathrm{gds}$ & [204] \\
\hline & & Trametes versicolor & $1.9 \mathrm{U} / \mathrm{gds}$ & [204] \\
\hline & Soya bran & Fomes sclerodermeus & $14.5 \mathrm{U} / \mathrm{gds}$ & [202] \\
\hline \multirow{14}{*}{$\begin{array}{l}\text { Manganese } \\
\text { peroxidase }\end{array}$} & \multirow{4}{*}{ Tree leaves (Fagus sylvatica) } & Lentinula edodes & $1.0-6.7 \mathrm{U} / \mathrm{L}$ & [151] \\
\hline & & Pleurotus dryinus & $5.7 \mathrm{U} / \mathrm{L}$ & [151] \\
\hline & & Pleurotus ostreatus & 7-15 U/L & [151] \\
\hline & & Pleurotus tuber-regium & $20 \mathrm{U} / \mathrm{L}$ & [151] \\
\hline & Wheat straw & $\begin{array}{c}\text { Lentinula edodes } \\
\text { Pleurotus dryinus } \\
\text { Pleurotus ostreatus } \\
\text { Pleurotus tuber-regium } \\
\text { Pleurotus citrinopileatus }\end{array}$ & $\begin{array}{c}20-55 \mathrm{U} / \mathrm{L} \\
13 \mathrm{U} / \mathrm{L} \\
7-12 \mathrm{U} / \mathrm{L} \\
2.2 \mathrm{U} / \mathrm{L} \\
4.9 \mathrm{U} / \mathrm{gds}\end{array}$ & $\begin{array}{l}{[151]} \\
{[151]} \\
{[151]} \\
{[151]} \\
{[200]}\end{array}$ \\
\hline & Wheat bran & $\begin{array}{l}\text { Fomes fomentarius } \\
\text { Pleurotus ostreatus } \\
\text { Trametes versicolor } \\
\text { Trametes biforme }\end{array}$ & $\begin{array}{c}350 \mathrm{U} / \mathrm{L} \\
20 \mathrm{U} / \mathrm{L} \\
20-50 \mathrm{U} / \mathrm{L} \\
570 \mathrm{U} / \mathrm{L}\end{array}$ & $\begin{array}{l}{[154]} \\
{[154]} \\
{[154]} \\
{[154]}\end{array}$ \\
\hline & Oat husk & Cerrena unicolor & $20.4 \mathrm{U} / \mathrm{gds}$ & [231] \\
\hline & Pineapple leaves & Ganoderma lucidum & $82.7 \mathrm{U} / \mathrm{gds}$ & [232] \\
\hline & Rice bran mixed wheat bran & Stereum ostrea & $3895 \mathrm{U} / \mathrm{L}$ & [233] \\
\hline & Rice straw & Schizophyllum commune & 1964 U/gsd & [234] \\
\hline & Eucalyptus sawdust & Lentinula edodes & $700 \mathrm{U} / \mathrm{gds}$ & [235] \\
\hline & Soya bran & Fomes sclerodermeus & $14.5 \mathrm{U} / \mathrm{gds}$ & [202] \\
\hline & $\begin{array}{l}\text { Sugarcane bagasse mixed } \\
\text { wheat bran }\end{array}$ & $\begin{array}{l}\text { Ganoderma lucidum } \\
\text { Pleurotus ostreatus } \\
\text { Tramets versicolor }\end{array}$ & $\begin{array}{l}1.9 \mathrm{U} / \mathrm{gds} \\
2.3 \mathrm{U} / \mathrm{gds} \\
2.1 \mathrm{U} / \mathrm{gds}\end{array}$ & $\begin{array}{l}{[204]} \\
{[204]} \\
{[204]}\end{array}$ \\
\hline & Barley husk & Bjerkandera adusta & $510 \mathrm{U} / \mathrm{kgds}$ & [236] \\
\hline \multirow{7}{*}{$\begin{array}{l}\text { Lignin } \\
\text { peroxidases }\end{array}$} & Jatropha waste & Pleurotus ostreatus & $49916 \mathrm{U} / \mathrm{L}$ & [237] \\
\hline & Corn cob & Ganoderma lucidum & $561.4 \mathrm{U} / \mathrm{gds}$ & [238] \\
\hline & Pineapple leaves & Ganoderma lucidum & $287.5 \mathrm{U} / \mathrm{gds}$ & [232] \\
\hline & Rice bran mixed wheat bran & Stereum ostrea & $72.8 \mathrm{U} / \mathrm{L}$ & [233] \\
\hline & Rice straw & Schizophyllum commune & $1467.3 \mathrm{U} / \mathrm{gsd}$ & [234] \\
\hline & Barley husk & Bjerkandera adusta & $1700 \mathrm{U} / \mathrm{kgds}$ & [236] \\
\hline & $\begin{array}{l}\text { Sugarcane bagasse mixed } \\
\text { wheat bran }\end{array}$ & $\begin{array}{l}\text { Ganoderma lucidum } \\
\text { Pleurotus ostreatus } \\
\text { Trametes versicolor }\end{array}$ & $\begin{array}{l}0.6 \mathrm{U} / \mathrm{gds} \\
0.5 \mathrm{U} / \mathrm{gds} \\
0.7 \mathrm{U} / \mathrm{gds}\end{array}$ & $\begin{array}{l}{[204]} \\
{[204]} \\
{[204]}\end{array}$ \\
\hline $\begin{array}{l}\text { Versatile } \\
\text { peroxidase }\end{array}$ & Banana peel & Pleurotus eryngii & $36 \mathrm{U} / \mathrm{gds}$ & [239] \\
\hline
\end{tabular}




\subsubsection{Laccases}

Laccases are a group of multicopper containing enzymes belonging to the blue multicopper oxidase family. The enzymes are also known as polyphenol oxidases, among which laccases oxidize one-electron of phenolic compounds with an associated reduction of oxygen to water as a by-product [240,241]. The enzymes do not require $\mathrm{H}_{2} \mathrm{O}_{2}$ for substrate oxidation. Lac can oxidize both phenolic aromatic compounds such as methylated phenol, aromatic amine and non-phenolic aromatic compounds such as veratryl alcohol in lignin to form phenoxy-free radicals. In this way, lignin degradation and lignin structural conversion can occur [242], as is shown in Figure 9. This oxidation process produces phenoxy radicals that can be converted to quinine by a second enzyme catalyzed reaction [166,243].<smiles>COc1cc(C(O)C(CO)O[GaH])cc(C)c1O</smiles>

Lignin<smiles></smiles>

Lignin
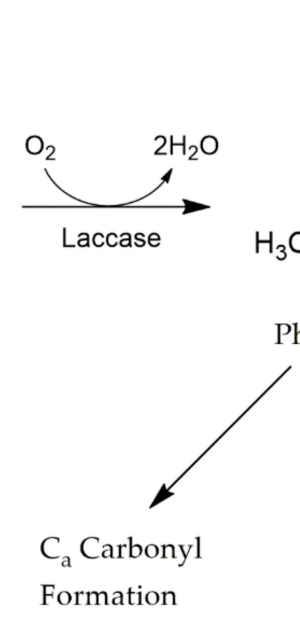<smiles>COc1cc(C(O)C(CO)O[GaH])cc(C)c1[O-]</smiles>

Phenoxy radical
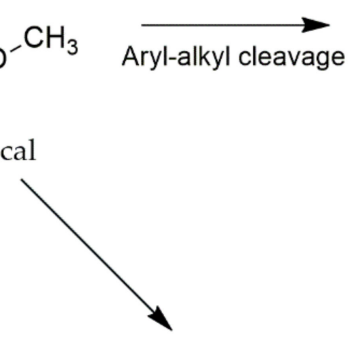

Polymerization and quinone formation

Figure 9. Typical reaction of laccase on phenols oxidation modifled from Minussi et al. [244].

Laccases contain four copper ions except for the laccase that is obtained from Phlebia radiata, which has only two copper ions [245]. There are three types of Lac depending on the copper number at the active site [246]. Type I: copper does not bind $\mathrm{O}_{2}$ but functions only as an electron transfer site. The type I copper center consists of a single copper atom that is coordinated with two histidine residues and one cysteine residue. In some cases, a methionine motif serves as a ligand with a trinuclear center. The Type II copper center has two histidines and a water molecule that serves as a ligand. The type III copper center contains two copper atoms that each possess three histidine ligands and are linked to one another via a hydroxide bridging ligand. Most of the studies on Lac have reported that the fungi and mushrooms present in basidiomycetes, deuteromycetes and ascomycetes act as Lac producers [247]. Among these fungi, the major Lac producers are white-rot fungi in basidiomycetes [246]. White-rot fungi Pycnoporus cinnabarinus, Phlebia radiate, P. ostreatus, and T. versicolour are also known to produce one isoform of Lac [248]. Cotton stalks, aromatic compounds, wood, and plant extracts were found to be inducers for Lac production [249]. For Lac production, extracted 3-hydroxyanthranilic acid (3-HAA) obtained from wheat straw was found to be a potential Lac stimulator [250]. The mixture of coffee pulp and urea was also able to enhance the Lac activity in Py. sanguineus culture. Some researchers have found a novel Lac obtained from T. orientalis, which has a molecular mass of $44.0 \mathrm{kDa}$. The enzyme contains a typical copper II binding domain and shares three N-glycosylation sites. But it has no copper I binding domain [251] Dias and colleagues [252] have reported a new zymogram dried 2,2'-azino-bis(3-ethylbenzo- thiazoline-6-sulfonic acid) (ABTS)-impregnated discs assay for laccase activity detection, which is associated with easy assay and rapid screening. The laccase activity was determined at a wavelength of $420 \mathrm{~nm}$ by measuring the oxidation of ABTS in phosphate citrate buffer at a $\mathrm{pH}$ value of 4.0 [253]. The other guaiacol assay has been reported for laccase assay by 
Kalra et al. [254] to measure the reddish-brown color development at $450 \mathrm{~nm}$ as a consequence of the oxidation of guaiacol by Lac.

\subsubsection{Lignin Peroxidases}

Lignin peroxidase ( $\mathrm{LiP}$ ) belongs to the family of oxidoreductases. LiP has ferric heme as an electron donor which is able to reduce oxygen molecules to hydrogen peroxidase and superoxides. LiP-Fe(III) uses $\mathrm{H}_{2} \mathrm{O}_{2}$ to oxidize aryl cation radicals as the initial substrate. The resulting amount of the lacked electron LiP is not stable and draws electrons from the substrate for stability of the electron condition. Finally, the oxidation cycle ends when LiP-Fe(IV) is turned to the resting ferric state [255]. This reaction exhibits a degree of stoichiometry of one $\mathrm{H}_{2} \mathrm{O}_{2}$ compound consumed per the amount of aldehyde formed. LiP is a strong oxidant and is non-specific with a substrate. It can degrade both structures of phenolic aromatic and non-phenolic aromatic compounds. Veratryl alcohol was found to be an inducer of LiP that was produced from white-rot fungi. The molecular weight of LiP was approximately $41 \mathrm{kDa}$ and contains one mole of Fe protoporphyrin IX. It is a glycoprotein with isoelectric point (pI) as 3.2-4.0 that displays high redox potential activity and an optimum pH value at 3.0 [250].

There are two methods for lignin peroxidase detection [250]. One involves the measurement of veratraldehyde from veratryl alcohol oxidation using a UV spectrophotometer at $310 \mathrm{~nm}$. One unit of activity is defined as one micromole of veratryl alcohol oxidized in one min, while the activities are reported in units/L (U/L). The 1,2-bis(3,4-dimethoxyphenyl) propane-1,3-diol is a substrate of this enzyme, whereas 3,4-dimethoxybenzaldehyde, 1-(3,4-dimethoxyphenyl) ethane-1,2-diol, and $\mathrm{H}_{2} \mathrm{O}$, are its products, as is displayed in Figure 10.

(A)<smiles>COc1ccc(C(O)C(CO)c2ccc(OI)c(OC)c2)cc1OC</smiles>

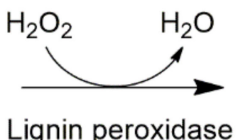<smiles>COc1ccc(C(CO)CO)cc1OC</smiles><smiles>COc1cc(C=O)ccc1I</smiles>

(B)<smiles>COc1ccc(CO)cc1OC</smiles>

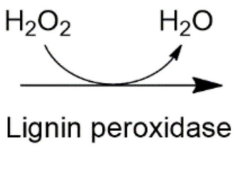

Veratryl alcohol<smiles>COc1ccc(C=O)cc1OC</smiles>

Veratraldehyde

Figure 10. General reaction catalyzed by lignin peroxidase. (A) cleavage of C-C of lignin, (B) oxidation of veratryl alcohol is generally used to estimate the lignin peroxidase activity.

The other method is the Azure B assay. In this method, the relevant reaction assay contains Azure $\mathrm{B}$ dye, $\mathrm{H}_{2} \mathrm{O}_{2}$, and sodium tartrate buffer ( $\mathrm{pH}$ 4.5). The activity is measured at a $615 \mathrm{~nm}$ wavelength [256]. This method has been identified as a good assay to reduce the turbidity caused by organic materials under the UV range. Mushrooms have been found as the first LiP producers, namely T. versicolor, P. ostreatus, G. lucidum, and Bjerkandera spices [232,257]. 


\subsubsection{Manganese Peroxidase}

Manganese peroxidase $(\mathrm{MnP})$ belongs to the family of oxidoreductases and cannot react directly with the lignin structure [250]. There are two groups: (1) Manganese dependent peroxidase is an extracellular enzyme that requires both $\mathrm{H}_{2} \mathrm{O}_{2}$ for lignin oxidation, $\mathrm{Mn}^{2+}$ as a co-factor and (2) Manganese independent peroxidase is an extracellular enzyme that requires $\mathrm{H}_{2} \mathrm{O}_{2}$ in lignin oxidation but does not need $\mathrm{Mn}^{2+}$ (Figure 11) [258]. The major substrates of manganese peroxidase are low molecular weight substances and organic acid compounds. In the mechanism cycle of lignin degradation, $\mathrm{Mn}^{2+}$ is an electron donor and $\mathrm{MnP}$ is oxidized by $\mathrm{H}_{2} \mathrm{O}_{2}$ as follows:

$$
\begin{gathered}
\text { "MnP }+\mathrm{H}_{2} \mathrm{O}_{2} \rightarrow \mathrm{MnP} \text { compound } \mathrm{I}+\mathrm{H}_{2} \mathrm{O}^{\prime} \\
\text { "MnP compound } \mathrm{I}+\mathrm{Mn}^{2+} \rightarrow \mathrm{MnP} \text { compound } \mathrm{II}+\mathrm{Mn}^{3+} " \\
\text { "MnP compound } \mathrm{II}+\mathrm{Mn}^{2+} \rightarrow \mathrm{MnP}+\mathrm{Mn}^{3+}+\mathrm{H}_{2} \mathrm{O}^{\prime}
\end{gathered}
$$<smiles>COc1cc(C(O)C(CO)O[GaH])cc(C)c1O</smiles>

Lignin

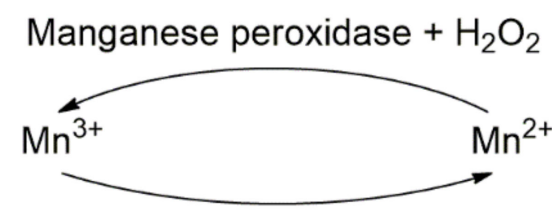

Phenoxy radical<smiles>COc1cc(C(O)C(CO)O[GaH])cc(C)c1[O-]</smiles>

Figure 11. Lignin depolymerisation with manganese peroxidase [259].

The electron-lacking MnP is nonstable and accepts an electron from $\mathrm{Mn}^{2+}$ to $\mathrm{Mn}^{3+}$ that then reacts with certain organic acid chelators such as oxalate, malonate, and lactate. The chelated-Mn ${ }^{3+}$ will act as a mediator to oxidize simple phenols, amines, and phenolic lignins. The enzyme can oxidize both phenolic and non-phenolic lignins [260]. The 3,3'-diaminobenzidine (DAB) assay [261] and manganese peroxidase $(\mathrm{MnP})$ assay [262] are the methods used for identification of peroxidase using $0.01 \%$ phenol red or $2 \mathrm{mM}$ 2,6-dimethoxyphenol (DMP) as a substrate.

Many mushroom species have been identified as MnP-producing fungi, especially P. ostreatus and Ph. chrysosporium [263]. Manganese dependent peroxidase is produced from P. pulmonarius, which can oxidize both non-phenolic and phenolic compounds for xenobiotic compound degradation. Kuhar and co-workers [264] have reported that $\mathrm{MnCl}_{2}$ can induce $\mathrm{MnP}$ activity and has a high specificity for $\mathrm{Mn}^{2+}$ binding sites.

\subsubsection{Versatile Peroxidase}

Versatile peroxidase (VP) is also known as a hybrid peroxidase or polyvalent peroxidase for $\mathrm{Mn}^{2+}$ oxidation. VP includes both LiP and MnP activities. Consequently, VP is able to degrade a wider range of substrates than non-hybrid enzymes. VP requires $\mathrm{H}_{2} \mathrm{O}_{2}$ as an electron acceptor to catalyze the oxidative reaction at the heme center with the release of a water molecule [250]. VP is a heme-containing glycoprotein that has a two-channel structure: the wider channel for access to $\mathrm{H}_{2} \mathrm{O}_{2}$ and the narrow channel for access to manganese. Low molecular substrates will be oxidized at the heme center by $\mathrm{H}_{2} \mathrm{O}_{2}$-ferric state binding (heme forming iron peroxide complex). This activated heme complex is able to oxidize the aromatic substrate using $\mathrm{Mn}^{2+}$, and then secretes $\mathrm{Mn}^{3+}$ and water [265] (Figure 12). VP has been produced by SSF of P. eryngii and P. ostreatus on wheat straw, sawdust, and banana peels $[223,266]$. Pleurotus ostreatus and Bjerkandera sp. were cultured in glucose-peptone broth and 
glucose ammonium medium using submerged fermentation for VP production [267]. The molecular weight and PI of VP obtained from P. eryngii were approximately $40 \mathrm{kDa}$ and 4.1, respectively [268]. The VP activity can be determined by monitoring manganese oxidation and Reactive clack (RB5) decolorization [267].

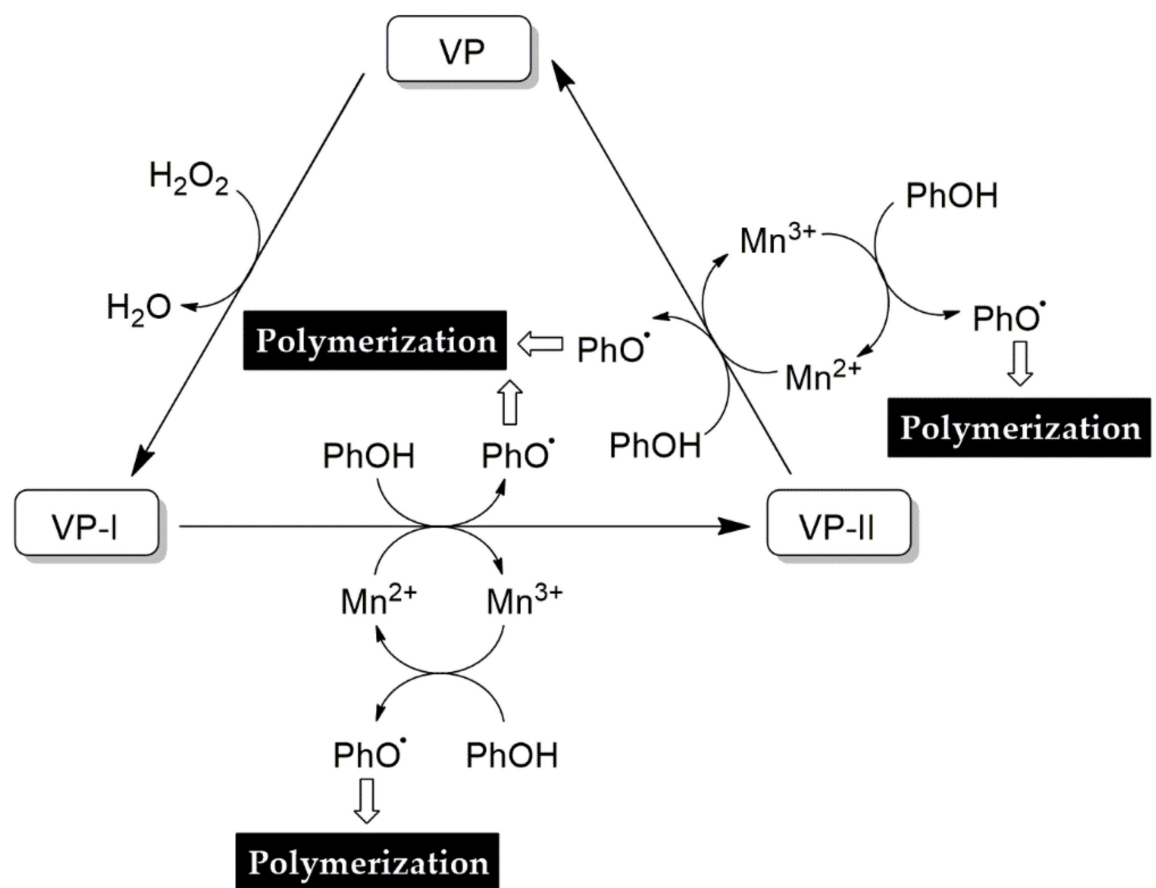

Figure 12. Scheme of the versatile peroxidase catalytic cycle [265].

\subsubsection{Dye Decolorizing Peroxidases}

Dye decolorizing peroxidases (DyPs) are a new family of glycoproteins that have one heme as a cofactor occurring in basidiomycetous fungi and eubacteria. DyPs require $\mathrm{H}_{2} \mathrm{O}_{2}$ as an electron acceptor and are similar to VP; however, DyPs can oxidize the high-redox potential anthraquinone dyes in addition to typical peroxidase substrates such as RBs, phenols, veratryl alcohol $[269,270]$. There are four types of DyPs from A to D based on their primary sequences [271]. However, type A DyPs has been reported as the potential type that is most effective in lignin depolymerization. The important characteristic of DyPs is the degradation of hydroxyl-free anthraquinone, which is not a substrate of other peroxidases [270]. DyPs can oxidize certain phenolic compounds such as 2,6-dimethoxyphenol and guaiacol. Only a few types of fungi can produce DyPs, especially type D-DyP, whereas they are mostly present in bacteria (types A, B, and C). The first DyP was discovered in B. adusta [272]. The wood-rotting fungi A. auricula-jadae, Mycetinis scorodonius, Exidia glandulosa, P. sapidus DSM8266 and Mycena epipterygia have also been reported as DyPs producers [273,274]. White-rot fungus, Irpex lacteus CD2, exhibited DyPs activity when it was grown in Kirk's medium containing lignins [275]. Many previous publications have reported that DyPs might be important for the ligninolytic system in white-rot fungi despite the fact that the biological roles of DyPs are unknown in terms of different substrate specificities. The mechanism of DyPs is similar to that of plant peroxidase, which is known to generate transient intermediates (compound I and compound II). The reaction of compound I with 1 eq electrons from a reducing substrate generates the [FeIV $=\mathrm{O}^{+}$intermediate compound II [271]. The optimum $\mathrm{pH}$ value of DyPs is acidic [276]. DyPs activity was assayed by the decolorization of an anthraquinone dye RB19 at $595 \mathrm{~nm}$ [275]. 


\subsection{Application of Lignocellulolytic Enzymes in Bioprocessing}

Enzyme technology possesses great potential to reduce environmental pollution and offers potential benefits in the comprehensive utilization of lignocellulosic biomass. Lignocellulolytic enzymes have received attention because of their potential applications in various agro-industrial bioprocesses, such as the conversion of hemicellulosic biomass to fuels and chemical production, the clarification of juices, the green processing of certain foods and beverages, the enhancement of animal digestibility in feedstock, the delignification of paper and pulp, the improvement of fabric properties in the textile industry and waste utilization [277-279]. Cellulase is widely used in the textile and laundry detergent industries as it can play a part in the hydrolysis of cellulose and improve fabric properties for the textile industry and for cleaning textiles in the laundry detergent industry [154,280]. The food and beverage processing industries have used cellulase for the hydrolysis of cellulose during the drying of coffee beans and for the extraction of fruits and vegetables in juice production [281,282]. Cellulase, $\alpha$-L-arabinofuranosidases and other glycosidases have also been used in brewery and wine production [213,277]. The enzymatic hydrolysis of grapes utilizes $\alpha$-L-arabinofuranosidases and other glycosidases to enhance the flavor of wine by the release of free terpenols, an important aspect in the development of the aroma in wine. The enzyme treatment by $\alpha$-L-arabinofuranosidases during sourdough preparation in the bread industry delays the staling process of bread and increases the shelf life of bread [213]. This results in economic benefits in terms of the preservation of bread and bread storage issues. Enzyme technology has a significant potential to improve the properties of pulp. Cellulases, xylanase and other hemicellulases are commonly used enzymes to assist in pulp bleaching for the reduction of environmental pollution loads [283]. Cellulases are used to improve the performance of dissolved pulp [277]. Additionally, $\alpha$-L-arabinofuranosidases enhance the delignification of pulp in the bleaching process as it can cleave the arabionose side chain that inhibits the action of xylanase [213]. Laccase can be used for lignin removal in prehydrolysis of lignocellulosic biomass [284]. Xylanolytic enzymes have potential applications across food and feed industries [278]. A combination of $\alpha$-L-arabinofuranosidases with cellulases, pectinases and xylanases enhance the feed digestibility and utilization of polysaccharides in feedstuffs [186,213]. Arabinoxylans are the major non-starch polysaccharide fractions in wheat, which increase digesta viscosity, reduce the digestibility of nutrients and decrease the feed efficiency and growth performance when fed to poultry, especially in broiler chickens [278]. Various reports have revealed the positive effects of MOS on intestinal microflora, along with efficient intestinal structure and function. MOS-based nutrition supplements are widely used in nutrition as a natural additive [279]. The treatment of copra meal rich in $\beta$-mannan with mannanase has been reported to reduce the population of Salmonella and Escherichia coli, increase the level of metabolizable energy and improve the nutrient digestibility in broilers [285]. Olaniyi et al. [207] reported that the treatment of cassava peels and corn cobs with mannanase increased the degradation of the complex carbohydrate fractions in the samples and resulted in increasing the amount of crude protein and certain mineral contents. Kim et al. [273] reported that the supplementation of $\beta$-mannanase for diet feeds does not mitigate the heat stress of aged laying hens raised under hot climatic conditions. Saeed et al. [206] describes the promising beneficial effects of $\beta$-mannanase in the poultry feed industry as the supplementation of $\beta$-mannanase in poultry diets that positively improved blood glucose and anabolic hormone homeostasis, digestible energy, and digestible amino acids. These enzymes have been used as food additives in the poultry raising industry and have been employed in the improvement of nutritional properties of agricultural silage and grain feed.

Manganese peroxidase is an important enzyme associated with the lignin and organic pollutant degradation systems, for instance bioremediation, dye decolorization, pulp bleaching, biomechanical pulping and in the production of a range of highly valuable products that have been obtained from residual lignins [286]. DyPs can be applied in the treatment of wastewater that contain synthetic dyes which are used in the manufacture of textiles, cosmetics, food, and pharmaceuticals. In the food industry, DyPs obtained from M. scorodonius, namely the MaxiBright@brand, are used to whiten whey 
in cheese making [274]. Enzymes have been extensively used in various industries as well as in a lot of the resulting products. Thus, genetic engineering is a powerful tool for the enhancement of ligninolytic enzyme production. White-rot fungus, Ph. chrysosporium, is a good model for the study of lignin degradation using DNA technology. The genome sequence encoded several genes such as ten lignin peroxidases, five manganese peroxidases, and several other lignocellulolytic enzymes [287,288]. Laser mutagenesis of Phellinus igniarius SJZ2 (mutant) overexpressed Lac activity during $4 \mathrm{~h}$ of fermentation and was increased by $36.84 \%$ in comparison with the wild type [242]. In addition to the overexpression of Lac in Saccharomyces cerevisiae using the laccase III (cvl3) gene obtained from T. versicolor, IFO1030 was secreted in the culture (45 U/L) [289]. Lignocellulosic enzymes are obtained from mushrooms, especially white-rot basidiomycetes, which are interesting tools in the biotechnological process that is used in a wide range of lignin substrates.

\section{Conclusions}

The utilization of agro-industrial waste in mushroom cultivation and the production of lignocellulolytic enzymes can facilitate the reduction of some global waste management problems. The cultivation of edible mushrooms using agro-industrial waste represents the bioconversion of that waste into edible protein. Different types of agro-industrial waste can be used for the cultivation of substrates for mushroom cultivation. However, the composition and availability of agro-industrial waste in each area has been considered for the support of mushroom cultivation. Different mushroom species and $\mathrm{C} / \mathrm{N}$ ratios in substrates are the crucial factors that affect the production and chemical composition of mushrooms. The nitrogen content of agro-industrial waste is low; therefore, this waste is generally associated with other nitrogen sources. The selected suitable substrate and mushroom species are important in obtaining the maximum yields.

Mushrooms seem to be the most important players in lignocellulose degradation by producing both hydrolytic and oxidative enzymes. Hydrolytic enzymes (cellulases and hemicellulases) are known to be responsible for polysaccharide degradation, while oxidative enzymes (ligninases) are responsible for lignin modification and degradation. Current results indicate that agro-industrial waste has been evaluated for its potential use in lignocellulosic enzyme production by mushrooms. However, the variability of waste composition and mushroom species are influential in enzyme production. Therefore, further studies are needed to demine the suitable conditions (substrates, mushroom species and fermentation process) for effective lignocellulosic enzyme production in the pilot study and on the industrial scale.

Author Contributions: The project approach was conceptually designed by J.K., N.S., S.L.; writing and original draft preparation, J.K., N.S., W.P., K.S., P.K., K.J., S.V.; chemical structure drawing, K.S.; the research was supervised by J.K., N.S., S.L.; All authors have read and agreed to the published version of the manuscript.

Funding: This research work was partially supported by Chiang Mai University.

Acknowledgments: We are grateful to Russell K. Hollis for the English proofreading of this manuscript.

Conflicts of Interest: The authors declare that they have no conflicts of interest.

\section{References}

1. Mirabella, N.; Castellani, V.; Sala, S. Current options for the valorization of food manufacturing waste: A review. J. Clean. Prod. 2014, 65, 28-41. [CrossRef]

2. Sadh, P.K.; Duhan, S.; Duhan, J.S. Agro-industrial wastes and their utilization using solid state fermentation: A review. Bioresour. Bioprocess 2018, 5, 1. [CrossRef]

3. Panesar, P.S.; Kaur, R.; Singla, G.; Sangwan, R.S. Bio-processing of agro-industrial wastes for production of food-grade enzymes: Progress and prospects. Appl. Food Biotechnol. 2016, 3, 4.

4. Ravindran, R.; Jaiswal, A.K. Exploitation of food industry waste for high-value products. Trends Biotechnol. 2016, 34, 58-69. [CrossRef] [PubMed] 
5. Anwar, Z.; Gulfraz, M.; Irshad, M. Agro-industrial lignocellulosic biomass a key to unlock the future bio-energy: A brief review. J. Radiat. Res. Appl. Sc. 2014, 7, 163-173. [CrossRef]

6. Cherubin, M.R.; Oliveira, D.M.D.S.; Feigl, B.J.; Pimentel, L.G.; Lisboa, I.P.; Gmach, M.R.; Varanda, L.L.; Morais, M.C.; Satiro, L.S.; Popin, G.V.; et al. Crop residue harvest for bioenergy production and its implications on soil functioning and plant growth: A review. Sci. Agricola 2018, 75, 255-272. [CrossRef]

7. da Silva, L.L. Adding value to agro-Industrial wastes. Ind. Chem. 2016, 2, e103. [CrossRef]

8. Hongzhang, C. Biotechnology of Lignocellulose: Theory and Practice; Springer: New York, NY, USA, 2016.

9. Sánchez, C. Lignocellulosic residues: Biodegradation and bioconversion by fungi. Biotechnol. Adv. 2009, 27, 185-194. [CrossRef]

10. Knob, A.; Forthamp, D.; Prolo, T.; Izidoro, S.C.; Almeida, J.M. Agro-residues as alternative for xylanase production by filamentous fungi. BioResources 2014, 9, 5738-5773.

11. Grimm, D.; Wösten, H.A.B. Mushroom cultivation in the circular economy. Appl. Microbiol. Biotechnol. 2018, 102, 7795-7803. [CrossRef]

12. Zhou, X.; Broadbelt, L.J.; Vinu, R. Mechanistic understanding of thermochemical conversion of polymers and lignocellulosic biomass. Adv. Chem. Eng. 2016, 49, 95-198.

13. Heinze, T. Cellulose: Structure and properties. In Cellulose Chemistry and Properties: Fibers, Nanocelluloses and Advanced Materials; Rojas, O., Ed.; Springer: Cham, Switzerland, 2016; Volume 271, pp. 1-52.

14. Jedvert, K.; Heinze, T. Cellulose modification and shaping-A review. J. Polym. Eng. 2017, 37, 845-860. [CrossRef]

15. Ebringerová, A.; Hromádková, Z.; Heinze, T. Hemicellulose. Adv. Polym. Sci. 2005, 186, 1-67.

16. Geneau-Sbartai, C.; Leyris, J.; Slivestre, F.; Rigal, L. Sunflower cake as a natural composite: Composition and plastic properties. J. Agric. Food Chem. 2008, 56, 11198-11208. [CrossRef]

17. Rico-García, D.; Ruiz-Rubio, L.; Pérez-Alvarez, L.; Hernández-Olmos, S.L.; Guerrero-Ramírez, G.L.; Vilas-Vilela, J.L. Lignin-based hydrogels: Synthesis and applications. Polymers 2020, 12, 18. [CrossRef]

18. Davin, L.B.; Lewis, N.G. Lignin primary structures and diligent sites. Curr. Opin. Biotechnol. 2005, 16, 407-415. [CrossRef]

19. Nawirska, A.; Kwaśniewska, M. Dietary fibre fractions from fruit and vegetable processing waste. Food Chem. 2005, 91, 221-225. [CrossRef]

20. Silveira, M.L.L.; Furlan, S.A.; Ninow, J.L. Development of an alternative technology for the oyster mushroom production using liquid inoculum. Cienc. Technol. Aliment. 2008, 28, 858-862. [CrossRef]

21. Tarrés, Q.; Espinosa, E.; Domínguez-Robles, J.; Rodríguez, A.; Mutjé, P.; Aguilar, M.D. The suitability of banana leaf residue as raw material for the production of high lignin content micro/nano fibers: From residue to value-added products. Ind. Crop. Prod. 2017, 99, 27-33. [CrossRef]

22. Nigam, P.S.; Gupta, N.; Anthwal, A. Pre-treatment of agro-industrial residues. In Biotechnology for Agro-Industrial Residues Utilization; Nigam, P.S., Pandey, A., Eds.; Springer: Dordrecht, The Nederlands, 2009; pp. 13-33.

23. Adapa, P.K.; Tabil, L.G.; Schoenau, G.J.; Canam, T.; Dumonceaux, T. Quantitative ananlysis of lignocellulosic companents of non-treated and stream exploded barley, canola, oat and wheat straw using fourier transform infrared spectroscopy. J. Agric. Sci. Technol. 2011, B1, 177-188.

24. Carrijo, O.A.; Liz, R.S.; Makishima, N. Fiber of green coconut shell as an agricultural substrate. Hortic. Bras. 2002, 20, 533-535. [CrossRef]

25. Graminha, E.B.N.; Gonçalvez, A.Z.L.; Pirota, R.D.P.B.; Balsalobre, M.A.A.; da Silva, R.; Gomes, E. Enzyme production by solid-state fermentation: Application to animal nutrition. Anim. Feed Sci. Technol. 2008, 144, 1-22. [CrossRef]

26. Gouvea, B.M.; Torres, C.; Franca, A.S.; Oliveira, L.S.; Oliveira, E.S. Feasibility of ethanol production from coffee husks. Biotechnol. Lett. 2009, 31, 1315-1319. [CrossRef] [PubMed]

27. Rofiqah, U.; Kurniawan, A.; Aji, R.W.N. Effect of temperature in ionic liquids pretreatment on structure of lignocellulose from corncob. J. Phys. Conf. Ser. 2019, 1373, 1-7. [CrossRef]

28. Pointner, M.; Kuttner, P.; Obrlik, T.; Jager, A.; Kahr, H. Composition of corncobs as a substrate for fermentation of biofuels. Agron. Res. 2014, 12, 391-396.

29. El-Tayeb, T.S.; Abdelhafez, A.A.; Ali, S.H.; Ramadan, E.M. Effect of acid hydrolysis and fungal biotreatment on agro-industrial wastes for obtainment of free sugars for bioethanol production. Braz. J. Microbiol. 2012, 43, 1523-1535. [CrossRef] 
30. Sun, Y.; Chen, J. Hydrolysis of lignocellulosic material for ethanol production: A review. Bioresour. Technol. 2002, 83, 1-11. [CrossRef]

31. Abbas, A.; Ansumali, S. Global potential of rice husk as a renewable feedstock for ethanol biofuel production. Bioenerg. Res. 2010, 3, 328-334. [CrossRef]

32. Limayema, A.; Ricke, S.C. Lignocellulosic biomass for bioethanol production: Current perspectives, potential issues and future prospects. Prog. Energy Comb. Sci. 2012, 38, 449-467. [CrossRef]

33. Buzala, K.; Przybysz, P.; Rosicka-Kaczmarek, J.; Kalinowska, H. Comparison of digestibility of wood pulps produced by the sulfate and TMP methods and woodchips of various botanical origins and sizes. Cellulose 2015, 22, 2737-2747. [CrossRef]

34. Chuayplod, P.; Aht-ong, D. A study of microcrystalline cellulose prepared from parawood (Hevea brasiliensis) sawdust waste using different acid types. J. Met. Mater. Miner. 2018, 28, 106-114.

35. Da Silva Neta, J.M.; Oliveira, L.S.C.; da Silva Flavio, L.H.; Tabosa, J.N.; Pacheco, J.G.A.; da Silva, M.J.V. Use of sweet sorghum bagasse (Sorghum bicolor (L.) Moench) for cellulose acetate synthesis. BioResources 2019, 14, 3534-3553.

36. Dong, M.; Wang, S.; Xu, F.; Wang, J.; Yang, N.; Li, Q.; Chen, J.; Li, W. Pretreatment of sweet sorghum straw and its enzymatic digestion: Insight into the structural changes and visualization of hydrolysis process. Biotechnol. Biofuels. 2019, 12, 276. [CrossRef]

37. Cardoso, W.S.; Tardin, F.D.; Tavares, G.; Queiroz, P.V.; Mota, S.S.; Kasuya, M.C.M.; de Queiroz, J.H. Use of sorghum straw (Sorghum bicolor) for second generation ethanol production: Pretreatment and enzymatic hydrolysis. Quim. Nova 2013, 36, 623-627. [CrossRef]

38. Dos Santos, R.M.; Neto, W.P.F.; Silverio, H.A.; Martins, D.F. Cellulose nanocrystals from pineapple leaf, a new approach for the reuse of this agro-waste. Ind. Crops Prod. 2013, 50, 707-714. [CrossRef]

39. Choonut, A.; Saejong, M.; Sangkharak, K. The Production of ethanol and hydrogen from pineapple peel by Saccharomyces cerevisiae and Enterobacter aerogenes. Energy Procedia 2014, 52, 242-249. [CrossRef]

40. Taher, I.B.; Fickers, P.; Chnitit, S.; Hassouna, M. Optimization of enzymatic hydrolysis and fermentation conditions for improved bioethanol production from potato peel residues. Biotechnol. Prog. 2017, 33, 397-406. [CrossRef]

41. Rivas, B.; Torrado, A.; Torre, P.; Converti, A.; Domínguez, J.M. Submerged citric acid fermentation on orange peel autohydrolysate. J. Agric. Food. Chem. 2008, 56, 2380-2387. [CrossRef]

42. Ververis, C.; Georghiou, K.; Danielidis, D.; Hatzinikolaou, D.G.; Santas, P.; Santas, R.; Corleti, V. Cellulose, hemicelluloses, lignin and ash content of some organic materials and their suitability for use as paper pulp supplements. Bioresour. Technol. 2007, 98, 296-301. [CrossRef] [PubMed]

43. Szymánska-Chargot, M.; Chylińska, M.; Gdula, K.; Koziol, A.; Zdunek, A. Isolation and characterization of cellulose from different fruit and vegetable pomaces. Polymers 2017, 9, 495. [CrossRef] [PubMed]

44. Motte, J.C.; Trably, E.; Escudié, R.; Hamelin, J.; Steyer, J.P.; Bernet, N.; Delgenes, J.P.; Dumas, C. Total solids content: A key parameter of metabolic pathways in dry anaerobic digestion. Biotechnol. Biofuels 2013, 6, 164. [CrossRef]

45. Zhao, X.; Peng, F.; Cheng, K.; Liu, D. Enhancement of enzymatic digestibility of sugarcane bagasse by alkali-peracetic acid pretreatment. Enzyme Microbial. Technol. 2009, 44, 17-23. [CrossRef]

46. Moutta, R.O.; Chandel, A.K.; Rodrigues, R.C.L.B.; Silva, M.B.; Rocha, G.J.M.; da Silva, S.S. Statistical optimization of sugarcane leaves hydrolysis into simple sugars by dilute sulfuric acid catalyzed process. Sugar Technol. 2012, 13, 53-60. [CrossRef]

47. Saad, M.B.W.; Oliveira, L.R.M.; Candido, R.G.; Quintana, G.; Rocha, G.J.M.; Goncalves, A.R. Preliminary studies on fungal treatment of sugarcane straw for organosolv pulping. Enzyme Microbial. Technol. 2008, 45, 220-225. [CrossRef]

48. Ariffin, H.; Hassan, M.A.; Umi Kalsom, M.S.; Abdullah, N.; Ghazali, F.M.; Shirai, Y. Production of bacterial endoglucanase from oil palm empty fruit bunch by Bacillus pumilus EB3. J. Biosci. Bioeng. 2008, 3, 231-2236. [CrossRef] [PubMed]

49. Zainudin, M.H.M.; Rahman, N.A.; Abd-Aziz, S.; Funaoka, M.; Shinano, T.; Shirai, Y. Utilization of glucose recovered by phase separation system from acid-hydrolysed oil palm empty fruit bunch for bioethanol production. Sci. Pertanika J. Trop. Agric. 2012, 35, 117-126. 
50. Tufail, T.; Saeed, F.; Imran, M.; Arshammad, M.U.; Anjum, F.M.; Afzaal, M.; Ain, H.B.U.; Shahbaz, M.; Gondal, T.A.; Hussain, S. Biochemical characterization of wheat straw cell wall with special reference to bioactive profile. Int. J. Food Prop. 2018, 21, 1303-1310. [CrossRef]

51. Li, X.; Liu, Y.; Hao, J.; Wang, W. Study of almond shell characteristics. Materials 2018, 11, 1782. [CrossRef]

52. Xinyuan, J.; Yuanyuan, L.; Zhong, G.; An, M.; Zecai, H.; Suwen, Y. Pyrolysis characteristics and correlation analysis with the major components of seven kinds of nutshell. Sci. Silvae Sin. 2015, 51, 79-86.

53. Akgül, M.; Korkut, S.; Camlibel, O.; Ayata, Ü. Some chemical properties of Luffa and its suitability for medium density fiberboard (MDF) production. Bioresurse 2013, 8, 1709-1717. [CrossRef]

54. Rodríguez, G.; Lama, A.; Rodríguez, R.; Jiménez, A.; Guillén, R.; Fernandez-Bolanos, J. Olive stone an attractive source of bioactive and valuable compounds. Bioresour. Technol. 2008, 99, 5261-5269. [CrossRef] [PubMed]

55. Ndika, E.V.; Chidozie, U.S.; Ikechukwu, U.K. Chemical modification of cellulose from palm kernel de-oiled cake to microcrystalline cellulose and its evaluation as a pharmaceutical excipient. Afr. J. Pure Appl. Chem. 2019, 13, 49-57.

56. FAOSTAT. Food and Agriculture Data. Available online: http://www.fao.org/faostat/en/\#home (accessed on 20 May 2020).

57. Kalač, P. A review of chemical composition and nutritional value of wild-growing and cultivated mushrooms. J. Sci. Food Agric. 2013, 93, 209-218. [CrossRef]

58. Valverde, M.E.; Hernándea-Pérez, T.; Paredes-López, O. Edible mushrooms: Improving human health and promoting quality life. Int. J. Microbial. 2015, 376-387. [CrossRef]

59. Cheung, P.C.K. The nutritional and health benefits of mushrooms. Nutr. Bull. 2010, 35, 292-299. [CrossRef]

60. Ma, G.; Yang, W.; Zhao, L.; Pei, F.; Fang, D.; Hu, Q. A critical review on the health promoting effects of mushrooms nutraceuticals. Food Sci. Hum. Wellness 2018, 7, 125-133. [CrossRef]

61. Royse, D.J.; Baars, J.; Tan, Q. Current overview of mushroom production in the world. In Edible and Medicinal Mushrooms: Technology and Applications; Zied, D.C., Pardo-Gimenez, A., Eds.; Wiley-Blackwell: West Sussex, UK, 2007; pp. 5-13.

62. Hoa, H.T.; Wang, C.; Wang, C. The effects of different substrates on the growth, yield, and nutritional composition of two oyster mushrooms (Pleurotus ostreatus and Pleurotus cystidiosus). Mycobiology 2015, 43, 423-434. [CrossRef]

63. Cueva, M.B.R.; Hernáadez, A.; Niňo-Ruiz, Z. Influence of $\mathrm{C} / \mathrm{N}$ ratio on productivity and the protein contents of Pleurotus ostreatus grown in differents residue mixtures. Rev. FCA Uncuyo. 2017, 49, 331-334.

64. Ragunathan, R.; Swaminathan, K. Nutritional status of Pleurotus spp. grown on various agro-wastes. Food Chem. 2003, 80, 371-375. [CrossRef]

65. Wang, D.; Sakoda, A.; Suzuki, M. Biological efficiency and nutritional value of Pleurotus ostreatus cultivated on spent beer grain. Bioresour. Technol. 2001, 78, 293-300. [CrossRef]

66. Carrasco, J.; Zied, D.C.; Pardo, J.E.; Preston, G.M.; Pardo-Gimenez, A. Supplementation in mushroom crops and its impact on yield and quality. AMB Expr. 2018, 8, 146. [CrossRef] [PubMed]

67. Moonmoon, M.; Shelly, N.J.; Khan, M.A.; Uddin, M.N.; Hossain, K.; Tania, M.; Ahmed, S. Effects of different levels of wheat bran, rice bran and maize powder supplementation with saw dust on the production of shiitake mushroom (Lentinus edodes (Berk.) Singer). Saudi J. Biol. Sci. 2011, 18, 323-328. [CrossRef] [PubMed]

68. Philippoussis, A. Production of mushrooms using agro-industrial residues as substrates. In Biotechnology for Agro-Industrial Residues Processing; Nigam, P.S., Pandey, A., Eds.; Springer: Dordrecht, The Netherlands, 2009; pp. 163-196.

69. Shekhar, H.S.; Kilpatrick, M. Mushroom (Agaricus bisporus) compost quality factor for predicting potential yield of fruiting bodies. Can. J. Microbiol. 2000, 46, 515-519.

70. Oei, P. Mushroom Cultivation, 3rd ed.; Backhuys Publishers: Leiden, The Netherlands, 2003; 429.

71. Lisiecka, J.; Sobieralski, K.; Siwulski, M.; Jasinska, A. Almond mushroom Agaricus brasiliensis (Wasser et al.)-properties and culture condition. Acta Sci. Pol. Hortorum Cultus 2013, 12, 27-40.

72. Cies, L. Resultados de dos ciclos de cultivo de champiñón Portobello. El Champiñón en Castilla-La Mancha 2009, 29, 1 .

73. Kopytowski, F.J.; Minhoni, M.T.A. C/N ratio on yield of Agaricus blazei Murrill ss. Heinemann. Mushroom Sci. 2004, 16, 213-220. 
74. Zied, D.C.; Savoie, J.; Pardo-Giménez, A. Soybean the main nitrogen source in cultivation substrates of edible and medicinal mushrooms. In Soybean and Nutrition; El-Shemy, H., Ed.; Janeza Trdine: Rijeka, Croatia, 2011; pp. 434-452.

75. Poppe, J.; Höfte, M. Twenty wastes for twenty cultivated mushroom. Mushroom Sci. 1995, 14, 171-179.

76. Chang, S.T.; Milles, P.G. Edible Mushroom and Their Cultivation; CRC Press: Florida, FL, USA, 1989; p. 345.

77. Chang-Ho, Y.; Ho, T.M. Effect of nitrogen amendment on the growth of Volvariella volvacea. Mushroom Sci. 1979, 10, 619-625.

78. Kaul, T.; Khurana, M.; Kachroo, J. Chemical composition of cereal straw of the Kashmir valley. Mushroom Sci. 1981, 11, 19-25.

79. Heltay, I.; Zavodi, I. Rice straw compost. Mushroom Sci. 1960, 4, 393-399.

80. Shi, L.; Chen, D.; Xu, C.; Ren, A.; Yu, H.; Zhao, M. Highly-efficient liposome-mediated transformation system for the basidiomycetous fungus Flammulina velutipes. J. Gen. Appl. Microbiol. 2017, 63, 179-185. [CrossRef] [PubMed]

81. Hsieh, C.; Yang, F.C. Reusing soy residue for the solid-state fermentation of Ganoderma lucidum. Bioresur. Technol. 2004, 91, 105-109. [CrossRef]

82. Wakchaure, G.C. Production and marketing of mushrooms: Global and national scenario. In Mushrooms Cultivation, Marketing and Consumption; Singh, M., Vijay, B., Kamal, S., Wakchaure, G.C., Eds.; ICAR Publishing: Solan, India, 2011; pp. 15-22.

83. Girmay, Z.; Gorems, W.; Birhanu, G.; Zewdie, S. Growth and yield performance of Pleurotus ostreatus (Jacq. Fr.) Kumm (oyster mushroom) on different substrates. AMB Expr. 2016, 6, 87. [CrossRef]

84. Toker, H.; Baysal, E.; Yigibasi, O.N.; Colak, M.; Perker, H.; Simsek, H.; Yilmaz, F. Cultivation of Agaricus bisporus on wheat straw and waste tea leaves based composts using poplar leaves as activator material. Afr. J. Biotechnol. 2007, 6, 204-212.

85. Tsai, S.Y.; Wu, T.P.; Huang, S.J.; Mau, J.L. Nonvolatile taste components of Agaricus bisporus harvested at different stages of maturity. Food Chem. 2007, 103, 1457-1464. [CrossRef]

86. Pardo-Giménez, A.; Pardo, J.E.; Dias, E.S.; Rinker, D.L.; Caitano, C.E.C.; Zied, D.C. Optimization of cultivation techniques improves the agronomic behavior of Agaricus subrufescens. Sci. Rep. 2020, 10, 8154. [CrossRef] [PubMed]

87. Koutrotsios, G.; Mountzouris, K.C.; Chatzipavlidis, I.; Zervakis, G.I. Bioconversion of lignocellulosic residues by Agrocybe cylindracea and Pleurotus ostreatus mushroom fungi-assessment of their effect on the final product and spent substrate properties. Food Chem. 2014, 161, 127-135. [CrossRef] [PubMed]

88. Hassan, F.R.H. Cultivation of the monkey head mushroom (Hericium erinaceus) in Egypt. J. App. Sci. Res. 2007, 3, 1229-1233.

89. Gaitán-Hernández, R.; Cortés, N.; Mata, G. Improvement of yield of the edible and medicinal mushroom Lentinula edodes on wheat straw by use of supplemented spawn. Braz. J. Microbiol. 2014, 45, 467-474. [CrossRef]

90. Patil, S.S. Productivity and proximate content of Pleurotus sajor-caju. Biosci. Discov. 2013, 4, 169-172.

91. Medany, G.M. Cultivation possibility of golden oyster mushroom (Pleurotus citrinopileatus) under the Egyptian conditions. Egypt. J. Agric. Res. 2014, 92, 749-761.

92. Ana, S.; Aak, A.; Aa, H.; Ea, S. Effect of residues agricultural wastes on the productivity and quality of Pleurotus colombinus 1 . by using polyethylene bags wall technique. Adv. Plants Agric. Res. 2016, 5, 528-536.

93. Telang, S.M.; Patil, S.S.; Baig, M.M.V. Comparative study on yield and nutritional aspect of Pleurotus eous mushroom cultivated on different substrate. Food Sci. Res. J. 2010, 1, 60-63.

94. Sardar, H.; Ali, M.A.; Anjum, M.A.; Nawaz, F.; Hussain, S.; Naz, S.; Karimi, S.M. Agro-industrial residues influence mineral elements accumulation and nutritional composition of king oyster mushroom (Pleurotus eryngii). Sci. Hort. 2017, 225, 327-334. [CrossRef]

95. Prasad, S.; Rathore, H.; Sharma, S.; Tiwari, G. Yield and proximate composition of Pleurotus florida cultivated on wheat straw supplemented with perennial grasses. Indian J. Agric. Sci. 2018, 88, 91-94.

96. Nasreen, Z.; Ali, S.; Usman, S.; Nazir, S.; Yasmeen, A. Comparative study on the growth and yield of Pleurotus ostreatus mushroom on lignocellulosic by-products. Int. J. Adv. Res. Bot. 2016, 2, 42-49.

97. Telang, S.M.; Patil, S.S.; Baig, M.M.V. Comparative study on yield and nutritional aspect of Pleurotus sapidus mushroom cultivated on different substrate. Food Sci. Res. J. 2010, 1, 127-129. 
98. De Andrade, M.C.N.; Zied, D.C.; Minhoni, M.T.A.; Filho, J.K. Yield of four Agaricus bisporus strains in three compost formulations and chemical composition analyses of the mushrooms. Braz. J. Microbial. 2008, 39, 593-598. [CrossRef]

99. De Carvalho, C.S.M.; Sales-Campos, C.; de Carvalho, L.P.; Minhoni, M.T.A.; Saad, A.L.M.; Alquati, G.P.; de Andrade, M.C.N. Cultivation and bromatological analysis of medicinal mushroom Ganoderma lucidum (Curt.: Fr.) P. Karst cultivated in agricultural waste. Afr. J. Biotechnol. 2015, 14, 412-418.

100. Gao, S.; Huang, Z.; Feng, X.; Bian, Y.; Huang, W.; Lui, Y. Bioconversion of rice straw agroresidues by Lentinula edodes and evaluation of non-volatile taste compounds in mushrooms. Sci. Rep. 2020, 10, 1814. [CrossRef] [PubMed]

101. Adenipekun, C.O.; Omolaso, P.O. Comparative study on cultivation, yield performance and proximate composition of Pleurotus pulmonarius Fries. (Quelet) on rice straw and banana leaves. World J. Agric. Sci. 2015, 11, 151-158.

102. Emriru, B.; Zenebech, K.; Kebede, F. Effect of substrates on the yield, yield attribute and dietary values of oyster mushroom (Pleurotus ostreatus) in the pastoral regions of northern Ethiopia. Afr. J. Food Agric. Nutr. Dev. 2016, 16, 11199-11218.

103. Ashraf, J.; Ali, M.A.; Ahmad, M.; Ayyub, C.M.; Shafi, J. Effect of different substrate supplements on oyster mushroom (Pleurotus spp.) production. Food Sci. Technol. 2013, 1, 44-51.

104. Biswas, M.K.; Layak, M. Techniques for increasing the biological efficiency of paddy straw mushroom (Volvariella volvacea) in eastern India. Food Sci. Technol. 2014, 2, 52-57.

105. Ahlawat, O.P.; Ahlawat, K.; Dhar, B.L. Influence of lignocellulolytic enzymes on substrate colonization and yield in monosporous isolates and parent strains of Volvariella volvacea (Bull. Fr.). Sing. India J. Microbiol. 2005, 45, 205-210.

106. Reyes, R.G.; Lopez, L.L.M.A.; Kumakura, K.; Kalaw, S.P.; Kikukawa, T.; Eguchi, F. Coprinus comatus, a newly domesticated wild nutriceutical mushroom in the Philippines. J. Argic. Tecnhol. 2009, 5, $299-316$.

107. Stojkovic, D.; Reis, F.S.; Barros, L.; Glamočlija, J.; Ćirić, A.; van Griensven, L.J.I.; Sokovic, M.; Ferreira, I.C.F.R. Nutrients and non-nutrients composition and bioactivity of wild and cultivated Coprinus comatus (O.F.Müll.). Pers. Food Chem. Toxicol. 2013, 59, 289-296. [CrossRef]

108. Salami, A.O.; Bankole, F.A.; Salako, Y.A. Nutrient and mineral content of oyster mushroom (Pleurotus florida) grown on selected lignocellulosic agro-waste substrates. Virol. Mycol. 2016, 5, 2.

109. Adedokun, O.M.; Akuma, A.H. Maximizing agricultural residues: Nutritional properties of straw mushroom on maize husk, wastes cotton and plantain leaves. Nat. Res. 2013, 4, 534-537. [CrossRef]

110. Ahmad, W.; Iqdal, J.; Salim, M.; Ahmad, I.; Sarwar, M.A.; Shehzad, M.A.; Rafiq, M.A. Performance of oyster mushroom (Pleurotus ostreatus) on cotton waste amended with maize and banana leaves. Pak. J. Nutr. 2011, 10, 509-513. [CrossRef]

111. Garuba, T.; Abdukkareem, K.A.; Ibrahim, I.A.; Oyebamiji, O.I.; Shoyooye, O.A.; Ajibade, T.D. Influence of substrates on the nutritional quality of Pleurotus pulmonarius and Pleurotus ostreatus. Ceylon J. Sci. 2017, 46, 67-74. [CrossRef]

112. Haq, I.U.; Khan, M.A.; Khan, S.A.; Ahmad, M. Biochemical analysis of fruiting bodies of Volvariella volvacea strain Vv pk, grown on six different substrates. Soil Environ. 2011, 30, 146-150.

113. Ahmed, S.A.; Kadam, J.A.; Mane, V.P.; Patil, S.S.; Baig, M.M.V. Biological efficiency and nutritional contents of Pleurotus florida (Mont.) Singer cultivated on different agro-wastes. Nat. Sci. 2009, 7, 44-48.

114. Herawati, E.; Arung, E.T.; Amirta, R. Domestication and nutrient analysis of Schizopyllum commune, alternative natural food sources in East Kalimantan. Agric. Agric. Sci. Procedia 2016, 9, 291-296. [CrossRef]

115. Triyono, S.; Haryanto, A.; Telaumbanua, M.; Lumbanraja, D.J.; To, F. Cultivation of straw mushroom (Volvariella volvacea) on oil palm empty fruit bunch growth medium. Int. J. Recycl. Org. Waste Agric. 2019, 8, 381-392. [CrossRef]

116. Familoni, T.V.; Ogidi, C.O.; Akinyele, B.J.; Onifade, A.K. Evaluation of yield, biological efficiency and proximate composition of Pleurotus species cultivated on different wood dusts. Czech Mycol. 2018, 70, 33-45. [CrossRef]

117. Salmones, D.; Mata, G.; Ramos, L.M.; Waliszewski, K.N. Cultivation of shiitake mushroom, Lentinula edodes, in several lignocellulosic materials originating from the subtropics. Agron. EDP Sci. 1999, 19, 13-19. [CrossRef] 
118. Selvakumar, P.; Rajasekar, S.; Babu, A.G.; Periasamy, K.; Raaman, N.; Reddy, M.S. Improving biological efficiency of Pleurotus strain through protoplast fusion between P. ostreatus var. florida and P. djamor var. roseus. Food Sci. Biotechnol. 2015, 24, 1741-1748.

119. Iqbal, B.; Khan, H.; Saifullah, L.; Khan, I.; Shah, B.; Naeem, A.; Ullah, W.; Khan, N.; Adnan, M.; Shah, S.R.A.; et al. Substrates evaluation for the quality, production and growth of oyster mushroom (Pleurotus florida Cetto). J. Entomol. Zool. Stud. 2016, 4, 98-107.

120. Sardar, A.; Satankar, V.; Jagajanantha, P.; Mageshwaran, V. Effect of substrates (cotton stalks and cotton seed hulls) on growth, yield and nutritional composition of two oyster mushrooms (Pleurotus ostreatus and Pleurotus florida). J. Cotton Res. Dev. 2020, 34, 135-145.

121. Kortei, N.K.; Dzogbefia, V.P.; Obodai, M. Assessing the effect of composting cassava peel based substrates on the yield, nutritional quality, and physical characteristics of Pleurotus ostreatus (Jacq. ex Fr.) Kummer. Biotechnol. Res. Int. 2014, 571520, 1-9. [CrossRef] [PubMed]

122. Apetorgbor, M.M.; Apetorgbor, A.K. Comparative studies on yield of Volvariella volvacea using root and tuber peels for improved livelihood of communities. J. Ghana Sci. Assoc. 2015, 16, 35-43.

123. Koutrotsios, G.; Patsou, M.; Mitsou, E.K.; Bekiaris, G.; Kotsou, M.; Tarantilis, P.A. Valorization of olive by-products as substrates for the cultivation of Ganoderma lucidum and Pleurotus ostreatus mushrooms with enhanced functional and prebiotic properties. Catalysts 2019, 9, 537. [CrossRef]

124. Liang, C.H.; Wu, C.Y.; Lu, P.L.; Kuo, Y.C.; Liang, Z.C. Biological efficiency and nutritional value of the culinary-medicinal mushroom Auricularia cultivated on a sawdust basal substrate supplement with different proportions of grass plants. Saudi J. Biol. Sci. 2019, 26, 263-269. [CrossRef]

125. Pati, S.S.; Ahmed, S.A.; Telang, S.M.; Baig, M.M.V. The nutritional value of Pleurotus ostreatus (Jacq.; Fr.) Kumm cultivated on different lignocellulosis agro-wastes. Innov. Rom. Food Biotechnol. 2010, 7, 66-76.

126. De Siqueira, F.G.; Martos, E.T.; da Silva, G.; da Silva, R.; Dias, E.S. Biological efficiency of Agaricus brasiliensis cultivated in compost with nitrogen concentrations. Hortic. Bras. 2011, 29, 157-161. [CrossRef]

127. Harith, N.; Abdullah, N.; Sabaratnam, V. Cultivation of Flammulina velutipes mushroom using various agro-residues as a fruiting substrate. Pesq. Agropec. Bras. 2014, 49, 181-188. [CrossRef]

128. Wiafe-Kwagyan, M.; Obadai, M.; Odamtten, G.T.; Kortei, N.K. The potential use of rice waste lignocellulose and its amendments as substrate for the cultivation of Pleurotus eous strain P-3 in Ghana. Int. J. Adv. Phar. Biol. Chem. 2016, 5, 116-130.

129. Bernardi, E.; Volcão, L.M.; Melo, L.G.; Nascimento, J.S. Productivity, biological efficiency and bromatological composition of Pleurotus sajor-caju growth on different substrates in Brazil. Agric. Nat. Resour. 2019, 53, 99-105.

130. Cragg, S.M.; Beckham, G.T.; Bruce, N.C.; Bugg, T.D.H.; Daniel, D.L.; Dupree, P.; Etxabe, A.G.; Goodell, B.S.; Jellison, J.; McGeehan, J.E.; et al. Lignocellulose degration mechanisms across the tree of life. Curr. Opin. Chem. Biol. 2015, 29, 108-119. [CrossRef] [PubMed]

131. Bredon, M.; Dittmer, J.; Noël, C.; Moumen, B.; Bouchon, D. Lignocellulose degradation at the holobiont level: Teamwork in a keystone soil invertebrate. Microbiome 2018, 6, 162. [CrossRef] [PubMed]

132. Eichorst, S.A.; Kuske, C.R. Identification of cellulose-responsive bacterial and fungal communities in geographically and edaphically different soils by using stable isotope probing. Appl. Environ. Microbiol. 2012, 78, 2316-2327. [CrossRef] [PubMed]

133. Andlar, M.; Rezić, T.; Marđetko, N.; Kracher, D.; Ludwig, R.; Santek, B. Lignocellulose degradation: An overview of fungi and fungal enzymes involved in lignocellulose degradation. Eng. Life Sci. 2018, 18, 768-778. [CrossRef]

134. Lombard, V.; Golaconda, R.H.; Drula, E.; Coutinho, P.M.; Henrissat, B. The carbohydrate-active enzymes database (CAZy) in 2013. Nucleic Acids Res. 2014, 42, 490-495. [CrossRef] [PubMed]

135. López-Mondéjar, R.; Zühlke, D.; Becher, D.; Riedel, K.; Baldrian, P. Cellulose and hemicellulose decomposition by forest soil bacteria proceeds by the action of structurally variable enzymatic systems. Sci. Rep. 2016, 6, 25279. [CrossRef] [PubMed]

136. Madeira, J.V., Jr.; Contesini, F.J.; Calzado, F.; Rubio, M.V.; Zubieta, M.P.; Lopes, D.B.; de Melo, R.R. Agro-industrial residues and microbial enzymes: An overview on the eco-friendly bioconversion into high value-added products. In Biotechnology of Microbial Enzymes; Brahmachari, G., Ed.; Elsevier: Amsterdam, The Netherlands, 2017; pp. 475-511. 
137. Ritota, M.; Manzi, P. Pleurotus spp. cultivation on different agri-food by-products: Example of biotechnological application. Sustainability 2019, 11, 5049. [CrossRef]

138. Horn, S.J.; Vaaje-Kolstad, G.; Westereng, B.; Eijsink, V. Novel enzymes for the degradation of cellulose. Biotechnol. Biofuels 2012, 5, 45. [CrossRef]

139. Sajith, S.; Priji, P.; Sreedevi, S.; Benjamin, S. An overview on fungal cellulases with an industrial perspective. J. Nutr. Food. Sci. 2016, 6, 461.

140. Yeoman, C.J.; Han, Y.; Dodd, D.; Schroeder, C.M.; Mackie, R.I.; Cann, I.K. Thermostable enzymes as biocatalysts in the biofuel industry. Adv. Appl. Microbiol. 2010, 70, 1-55.

141. Zhang, Y.H.P.; Himmel, M.E.; Mielenz, J.R. Outlook for cellulase improvement, screening and selection strategies. Biotechnol. Adv. 2006, 24, 452-481. [CrossRef] [PubMed]

142. Saini, K.J.; Saini, R.; Lakshmi Tewari, L. 2015. Lignocellulosic agriculture wastes as biomass feedstocks for second-generation bioethanol production: Concepts and recent developments. 3 Biotech 2015, 5, 337-353. [CrossRef]

143. Qi, M.; Jun, H.S.; Forsberg, C.W. Cel9D, an atypical 1,4- $\beta$-D-glucan glucohydrolase from Fibrobacter succinogenes: Characteristics, catalytic residues and synergistic interactions with other cellulases. J. Bacteriol. 2008, 190, 1976-1984. [CrossRef] [PubMed]

144. Pothiraj, C.; Balaji, P.; Eyini, M. Enhanced production of cellulases by various fungal cultures in solid state fermentation of cassava waste. Afr. J. Biotechnol. 2006, 5, 1882-1885.

145. Bansal, N.; Tewari, R.; Soni, R.; Soni, S.K. Production of cellulases from Aspergillus niger NS-2 in solid state fermentation on agricultural and kitchen waste residues. Waste Manag. 2012, 32, 1341-1346. [CrossRef] [PubMed]

146. Prasanna, H.N.; Ramanjaneyulu, G.; Rajasekhar Reddy, B. Optimization of cellulase production by Penicillium sp. 3 Biotech 2016, 6, 1-11. [CrossRef] [PubMed]

147. Ellilä, S.; Fonseca, L.; Uchima, C.; Cota, J.; Goldman, G.H.; Saloheimo, M.; Sacon, V.; Siika-aho, M. Development of a low-cost cellulase production process using Trichoderma reesei for Brazilian biorefineries. Biotechnol. Biofuels 2017, 10, 1-17. [CrossRef]

148. Reddy, G.V.; Babu, P.R.; Komaraiah, P.; Roy, K.R.R.M.; Kothari, I.L. Utilization of banana waste for the production of lignolytic and cellulolytic enzymes by solid substrate fermentation using two Pleurotus species (P. ostreatus and P. sajor-caju). Process. Biochem. 2003, 38, 1457-1462. [CrossRef]

149. Balaraju, K.; Park, K.; Jahagirdar, S.; Kaviyarasan, V. Production of cellulase and laccase enzymes by Oudemansiella radicata using agro wastes under solid-state and submerged conditions. Res. Biotechnol. 2010, 1, 21-28.

150. Pandey, V.K.; Singh, M.P. Biodegradation of wheat straw by Pleurotus ostreatus. Cell. Mol. Biol. 2014, 60, 29-34.

151. Elisashvili, V.; Chichua, D.; Kachlishvili, E.; Tsiklauri, N.; Khardziani, T. Lignocellulolytic enzyme activity during growth and fruiting of the edible and medicinal mushroom Pleurotus ostreatus (Jacq.: Fr.) Kumm. (Agaricomycetideae). Int. J. Med. Mushrooms 2003, 5, 193-198. [CrossRef]

152. Elisashvili, V.; Penninckx, M.; Kachlishvili, E.; Tsiklauri, N.; Metreveli, E.; Kharziani, T.; Kvesitadze, G. Lentinus edodes and Pleurotus species lignocellulolytic enzymes activity in submerged and solid state fermentation of lignocellulosic wastes of different composition. Bioresour. Technol. 2008, 99, 457-462. [CrossRef] [PubMed]

153. Montoya, S.; Orrego, C.E.; Levin, L. Growth, fruiting and lignocellulolytic enzyme production by the edible mushroom Grifola frondosa (maitake). World J. Microbiol. Biotechnol. 2012, 28, 1533-1541. [CrossRef] [PubMed]

154. Cardoso, W.S.; Queiroz, P.V.; Tavares, G.P.; Santos, F.A.; Soares, F.E.D.F.; Kasuya, M.C.M.; Queiroz, J.H.D. Multi-enzyme complex of white rot fungi in saccharification of lignocellulosic material. Braz. J. Microbiol. 2018, 49, 879-884. [CrossRef] [PubMed]

155. Elisashvili, V.; Kachlishvili, E.; Tsiklauri, N.; Metreveli, E.; Khardziani, T.; Agathos, S.N. Lignocellulose-degrading enzyme production by white-rot basidiomycetes isolated from the forests of Georgia. World J. Microbiol. Biotechnol. 2009, 25, 331-339. [CrossRef]

156. Chuwech, M.; Rakariyatham, N. Potential of peanut hulls as substrates for fungal cellulase bioproduction through solid state fermentation. Asia. Pac. J. Sci. Technol. 2014, 19, 235-343.

157. Lechner, B.E.; Papinutti, V.L. Production of lignocellulosic enzymes during growth and fruiting of the edible fungus Lentinus tigrinus on wheat straw. Process. Biochem. 2006, 41, 594-598. [CrossRef] 
158. Valášková, V.; Baldrian, P. Estimation of bound and free fractions of lignocellulose-degrading enzymes of wood-rotting fungi Pleurotus ostreatus, Trametes versicolor and Piptoporus betulinus. Res. Microbiol. 2006, 157, 119-124. [CrossRef]

159. Wu, Y.; Shin, H. Cellulase from the fruiting bodies and mycelia of edible mushrooms: A review. J. Mushrooms 2016, 14, 127-135. [CrossRef]

160. Deswal, D.; Khasa, Y.P.; Kuhad, R. Optimization of cellulose production by a brown rot fungus Fomitopsis sp. RCK2010 under solid state fermentation. Bioresour. Technol. 2011, 102, 6065-6072. [CrossRef]

161. Kachlishvili, E.; Penninckx, M.J.; Tsiklauri, N.; Elisashvili, V. Effect of nitrogen source on lignocellulolytic enzyme production by white rot basidiomycetes under solid state cultivation. World J. Microbial. Biotechnol. 2005, 224, 391-397.

162. Machuca, A.; Ferraz, A. Hydrolytic and oxidative enzymes produced by white- and brown-rot fungi during Eucalyptus grandis decay in solid medium. Enzym. Microb. Technol. 2001, 29, 386-391. [CrossRef]

163. Pandit, N.P.; Maheshwari, S.K. Optimization of cellulase enzyme production from sugarcane pressmud using oyster mushroom-Pleurotus sajor-caju by solid state fermentation. J. Bioremed. Biodegrad. 2012, 3, 1-5. [CrossRef]

164. Khalil, M.I.; Hoque, M.M.; Basunia, M.A.; Alam, N.; Khan, M.A. Production of cellulase by Pleurotus ostreatus and Pleurotus sajor-caju in solid state fermentation of lignocellulosic biomass. Turk. J. Agric. For. 2011, 35, 333-341.

165. Levin, L.; Herrmann, C.; Papinutti, V.L. Optimization of lignocellulolytic enzyme production by the white-rot fungus Trametes trogii in solid-state fermentation using response surface methodology. Biochem. Eng. J. 2008, 39, 207-214. [CrossRef]

166. Giorgio, E.M.; Fonseca, M.I.; Tejerina, M.R.; Ramos-Hryb, A.B.; Sanabria, N.; Zapata, P.D.; Villalba, L.L. Chips and sawdust substrates application for lignocellulolytic enzymes production by solid state fermentation. Int. Res. J. Microbiol. 2012, 3, 120-127.

167. Nguyen, K.A.; Kumla, J.; Suwannarach, N.; Penkhrue, W.; Lumyong, S. Optimization of high endoglucanase yields production from polypore fungus, Microporus xanthopus strain KA038 under solid-state fermentation using green tea waste. Bio 2019, 8, bio047183. [CrossRef]

168. Xu, C.; Ma, F.; Zhang, X. Lignocellulose degradation and enzyme production by Irpex lacteus CD2 during solid-state fermentation of corn stover. J. Biosci. Bioeng. 2009, 108, 372-375. [CrossRef] [PubMed]

169. Philippoussis, A.; Diamantopoulou, P. Agro-food industry wastes and agricultural residues conversion into high value products by mushroom cultivation. In Proceedings of the 7th International Conference on Mushroom Biology and Mushroom Products (ICMBMP7), Institute National de la Recherche Agronomique (INRA), Arcachon, France, 4-7 October 2011; pp. 339-351.

170. Dashtban, M.; Maki, M.; Leung, K.T.; Mao, C.; Qin, W. Cellulase activities in biomass conversion: Measurement methods and comparison. Critical. Rev. Biotechnol. 2010, 30, 302-309. [CrossRef] [PubMed]

171. Ghose, T.K. Measurement of cellulase activities. Pure Appl. Chem. 1987, 59, 257-268. [CrossRef]

172. Mandels, M.; Andreotti, R.; Roche, C. Measurement of saccharifying cellulase. Biotechnol. Bioeng. Symp. 1976, 6, 21-33.

173. Kubicek, C.P. Release of carboxymethyl-cellulase and $\beta$-glucosidase from cell walls of Trichoderma reesei. Eur. J. Appl. Biotechnol. 1981, 13, 226-231. [CrossRef]

174. Korotkova, O.G.; Semenova, M.V.; Morozova, V.V.; Zorov, I.N.; Sokolova, L.M.; Bubnova, T.M.; Okunev, O.N.; Sinitsyn, A.P. Isolation and properties of fungal beta-glucosidases. Biochemistry 2009, 74, 569-577. [PubMed]

175. Sørensen, A.; Lübeck, M.; Lübeck, P.S.; Ahring, B.K. Fungal beta-glucosidases: A bottleneck in industrial use of lignocellulosic materials. Biomolecules 2013, 3, 612-631. [CrossRef] [PubMed]

176. Scheller, H.V.; Ulvskov, P. Hemicelluloses. Annu. Rev. Plant Biol. 2010, 61, 263-289. [CrossRef] [PubMed]

177. De Souza, W.R. Microbial Degradation of Lignocellulosic Biomass. In Sustainable Degradation of Lignocellulosic Biomass-Techniques, Applications and Commercialization; Chandel, A.K., da Silva, S.S., Eds.; IntechOpen: London, UK, 2012; pp. 207-247.

178. Ahmed, S.; Jabeen, A.; Jamil, A. Xylanase from Trichoderma harzianum: Enzyme characterization and gene isolation. J. Chem. Soc. Pak. 2011, 29, 176.

179. Walia, A.; Guleria, S.; Mehta, P.; Chauhan, A.; Parkash, J. Microbial xylanases and their industrial application in pulp and paper biobleaching: A review. 3 Biotech 2017, 7, 11. [CrossRef] [PubMed] 
180. Vos, A.M.; Jurak, E.; de Gijsel, P.; Ohm, R.A.; Henrissat, B.; Lugones, L.G.; Kabel, M.A.; Wosten, H.A.B. Production of $\alpha-1,3-\mathrm{L}$-arabinofuranosidase active on substituted xylan does not improve compost degradation by Agaricus bisporus. PLoS ONE 2018, 13, e0201090. [CrossRef]

181. Dos Santos, C.R.; de Giuseppe, P.O.; de Souza, F.H.M.; Zanphorlin, L.M.; Domingues, M.N.; Pirolla, R.A.S.; Honorato, R.V.; Tonoli, C.C.C.; de Morais, M.A.B.; Martins, V.P.M.; et al. Murakami, M.T. The mechanism by which a distinguishing arabinofuranosidase can cope with internal di-substitutions in arabinoxylans. Biotechnol. Biofuels 2018, 11, 223. [CrossRef]

182. Gómez, S.; Payne, A.M.; Savko, M.; Fox, G.C.; Shepard, W.E.; Fernandez, F.J.; Vega, M.C. Structural and functional characterization of a highly stable endo- $\beta-1,4-x y l a n a s e$ from Fusarium oxysporum and its development as an efficient immobilized biocatalyst. Biotechnol. Biofuels 2016, 9, 191. [CrossRef]

183. Bajaj, P.; Mahajan, R. Cellulase and xylanase synergism in industrial biotechnology. Appl. Microbiol. Biot. 2019, 103, 8711-8724. [CrossRef]

184. Burlacu, A.; Cornea, C.P.; Israel-Roming, F. Screening of xylanase producing microorganisms. Res. J. Agric. Sci. 2016, 48, 8-15.

185. Meddeb-Mouelhi, F.; Moisan, J.K.; Beauregard, M. A comparison of plate assay methods for detecting extracellular cellulase and xylanase activity. Enzyme Microb. Technol. 2014, 66, 16-19. [CrossRef]

186. Lim, S.H.; Lee, Y.H.; Kang, H.W. Efficient recovery of lignocellulolytic enzymes of spent mushroom compost from oyster Mushrooms, Pleurotus spp., and potential use in dye decolorization. Mycobiology 2013, 41, 214-220. [CrossRef] [PubMed]

187. Amore, A.; Amoresano, A.; Birolo, L.; Henrissat, B.; Leo, G.; Palmese, A.; Faraco, V. A family GH51 $\alpha$-l-arabinofuranosidase from Pleurotus ostreatus: Identification, recombinant expression and characterization. Appl. Microbiol. Biotechnol. 2011, 94, 995-1006. [CrossRef] [PubMed]

188. Miller, G.L. Use of dinitrosalicylic acid reagent for determination of reducing sugar. Anal. Chem. 1959, 31, 426-428. [CrossRef]

189. Nelson, N. A photometric adaptation of Somogyi methods for determination of glucose. J. Biol. Chem. 1994, 153, 375-380.

190. Somogyi, M. Notes on sugar determination. J. Biol. Chem. 1952, 195, 19-23.

191. Azeri, C.; Tamer, A.U.; Oskay, M. Thermoactive cellulase-free xylanase production from alkaliphilic Bacillus strains using various agro-residues and their potential in biobleaching of kraft pulp. Afr. J. Biotechnol. 2010, 9 , 63-72.

192. Driss, D.; Bhiri, F.; Elleuch, L.; Bouly, N.; Stals, I.; Miled, N.; Blibech, M.; Ghorbel, R.; Chaabouni, S.E. Purification and properties of an extracellular acidophilic endo-1,4- $\beta$-xylanase, naturally deleted in the "thumb", from Penicillium occitanis Pol6. Proc. Biochem. 2012, 46, 1299-1306. [CrossRef]

193. Hatanaka, K. Incorporation of fluorous glycosides to cell membrane and saccharide chain elongation by cellular enzymes. Top. Curr. Chem. 2012, 308, 291-306.

194. Kuhad, R.C.; Sing, A. Lignocellulose biotechnology: Current and future prospects. Crit. Rev. Biotechnol. 1993, 13, 151-172. [CrossRef]

195. Soni, H.; Rawat, H.K.; Pletschke, B.I.; Kango, N. Purification and characterization of $\beta$-mannanase from Aspergillus terreus and its applicability in depolymerization of mannans and saccharification of lignocellulosic biomass. Biotech 2016, 6, 136. [CrossRef]

196. Sherief, A.A.; El-Tanash, A.B.; Temraz, A.M. Lignocellulolytic enzymes and substrate utilization during growth and fruiting of Pleurotus ostreatus on some solid wastes. J. Environ. Sci. Technol. 2010, 3, 18-34. [CrossRef]

197. Manavalan, T.; Manavalan, A.; Thangavelu, K.P.; Heese, K. Secretome analysis of Ganoderma lucidum cultivated in sugarcane bagasse. J. Proteom. 2012, 77, 298-309. [CrossRef]

198. Iandolo, D.; Piscitelli, A.; Sannia, G.; Faraco, V. Enzyme production by solid substrate fermentation of Pleurotus ostreatus and Trametes versicolor on tomato pomace. Appl. Biochem. Biotechnol. 2010, 163, 40-51. [CrossRef]

199. Zhu, N.; Liu, J.; Yang, J.; Lin, Y.; Yang, Y.; Ji, L.; Li, M.; Yuan, H. Comparative analysis of the secretomes of Schizophyllum commune and other wood-decay basidiomycetes during solid-state fermentation reveals its unique lignocellulose-degrading enzyme system. Biotechnol. Biofuels 2016, 9, 42. [CrossRef] [PubMed]

200. Steffen, K.T.; Cajthaml, T.; Snajdr, J.; Baldrian, P. Differential degradation of oak (Quercus petraea) leaf litter by litter-decomposing basidiomycetes. Res. Microbiol. 2007, 158, 447-455. [CrossRef] [PubMed] 
201. Carabajal, M.; Levin, L.; Albertó, E.; Lechner, B. Effect of co-cultivation of two Pleurotus species on lignocellulolytic enzyme production and mushroom fructification. Int. Biodeterior. 2012, 66, 71-76. [CrossRef]

202. Heidorne, F.O.; Magalhães, P.O.; Ferraz, A.L.; Milagres, A.M.F. Characterization of hemicellulases and cellulases produced by Ceriporiopsis subvermispora grown on wood under biopulping conditions. Enzyme Microb. Technol. 2006, 38, 436-442. [CrossRef]

203. Papinutti, V.L.; Forchiassin, F. Lignocellulolytic enzymes from Fomes sclerodermeus growing in solid-state fermentation. J. Food Eng. 2007, 81, 54-59. [CrossRef]

204. Boonrung, S.; Mongkolthanaruk, W.; Aimi, T.; Boonlue, S. Cellulase and xylanase acting at alkaline pH from mushroom, Leucoagaricus meleagris KKU-C1. Chiang Mai J. Sci. 2014, 41, 84-96.

205. De Oliveira Rodrigues, P.; Gurgel, L.V.A.; Pasquini, D.; Badotti, F.; Góes-Neto, A.; Baffi, M.A. Lignocellulose-degrading enzymes production by solid-state fermentation through fungal consortium among ascomycetes and basidiomycetes. Renew. Energy 2020, 145, 2683-2693. [CrossRef]

206. Chauhan, P.S.; Puri, N.; Sharma, P.; Gupta, N. Mannanases: Microbial sources, production, properties and potential biotechnological applications. Appl. Microbiol. Biot. 2012, 93, 1817-1830. [CrossRef] [PubMed]

207. Saeed, M.; Ayaşan, T.; Alagawany, M.; El-Hack, M.E.A.; Abdel-Latif, M.A.; Patra, A.K. The role of $\beta$-mannanase (Hemicell) in improving poultry productivity, health and environment. Braz. J. Poultry Sci. 2019, 21, 1-8. [CrossRef]

208. Olaniyi, O.O.; Bankefa, E.O.; Folasade, I.O.; Familoni, T.V. Nutrient enrichment of mannanase-treated cassava peels and corn cob. Res. J. Microbiol. 2015, 10, 533-541. [CrossRef]

209. Pinho, G.P.; Matoso, J.R.M.; Silvério, F.O.; Mota, W.C.; Lopes, P.S.N.; Ribeiro, L.M. A new spectrophotometric method for determining the enzymatic activity of endo- $\beta$-mannanase in seeds. J. Braz. Chem. Soc. 2014, 25, 1246-1252. [CrossRef]

210. Titapoka, S.; Keawsompong, S.; Haltric, D.; Nitisinprasert, S. Selection and characterization of mannanase-producing bacteria useful for the formation of prebiotic manno-ligosaccharides from copra meal. World J. Microbiol. Biotechnol. 2008, 24, 1425-1433. [CrossRef]

211. Maijala, P.; Kango, N.; Szijarto, N.; Viikari, L. Characterization of hemicellulases from thermophilic fungi. Anton. Leeuw. 2012, 101, 905-917. [CrossRef]

212. Wang, S.; Yang, Y.; Zhang, J.; Sun, J.; Matsukawa, S.; Xie, J.; Wei, D. Characterization of abnZ2 (yxiA1) and abnZ3 (yxiA3) in Paenibacillus polymyxa, encoding two novel endo-1,5- $\alpha$-L-arabinanases. Bioresour. Bioprocess. 2014, 1, 14. [CrossRef]

213. Seiboth, B.; Metz, B. Fungal arabinan and l-arabinose metabolism. Appl. Microbiol. Biotechnol. 2011, 89, 1665-1673. [CrossRef] [PubMed]

214. Numan, M.T.; Bhosle, N.B. $\alpha$-L-Arabinofuranosidases: The potential applications in biotechnology. J. Ind. Microbiol. Biotechnol. 2006, 33, 247-260. [CrossRef] [PubMed]

215. Yanay, T.; Sato, M. Purification and characterization of a novel $\alpha$-L-arabinofuranosidase from Pichia capsulata X91. Biosci. Biotechnol. Biochem. 2000, 64, 1181-1188. [CrossRef] [PubMed]

216. Jurak, E.; Patyshakuliyeva, A.; de Vries, R.P.; Gruppen, H.; Kabel, M.A. Compost grown Agaricus bisporus lacks the ability to degrade and consume highly substituted xylan fragments. PLoS ONE 2015, 10, e0134169. [CrossRef] [PubMed]

217. Anderson, W.F.; Akin, D.E. Structural and chemical properties of grass lignocelluloses related to conversion for biofuels. J. Ind. Microbiol. Biotechnol. 2008, 35, 355-366. [CrossRef]

218. Scharf, M.E.; Tartar, A. Termite digestomes as sources for novel lignocellulases. Biofuels Bioprod. Biorefin. 2008, 2, 540-552. [CrossRef]

219. Pollegioni, L.; Tonin, F.; Rosini, E. Lignin-degrading enzymes. FEBS J. 2015, 282, 1190-1213. [CrossRef]

220. Niladevi, K.N. Ligninolytic enzymes. In Biotechnology for Agro-Industrial Residues Utilisation; Nigam, P.S., Pandey, A., Eds.; Springer: Amsterdam, The Netherlands, 2009; pp. 397-414.

221. Rogalski, J.; Lundell, T.; Leonowicz, A.; Hatakka, A. Production of laccase, lignin peroxidase and manganese-dependent peroxidase by various strains of Trametes versicolor depending on culture conditions. Acta Microbiol. Pol. 1991, 40, 221-234.

222. Tripathi, A.; Upadhyay, R.C.; Singh, S. Extracellular Ligninolytic Enzymes in Bjerkandera adusta and Lentinus squarrosulus. Indian J. Microbiol. 2012, 52, 381-387. [CrossRef] 
223. Saeki, N.; Takeda, H.; Tanesaka, E.; Yoshida, M. Induction of manganese peroxidase and laccase by Lentinula edodes under liquid culture conditions and their isozyme detection by enzymatic staining on native-PAGE. Mycoscience 2011, 52, 132-136. [CrossRef]

224. Caramelo, L.; Martinez, M.J.; Martinez, A.T. A search for ligninolytic peroxidases in the fungus Pleurotus eryngii involving alpha-keto-gamma-thiomethylbutyric acid and lignin model dimers. Appl. Environ. Microbiol. 1999, 65, 916-922. [CrossRef]

225. Chmelová, D.; Ondrejovič, M. Effect of potential inductors on laccase production by white-rot fungus Ceriporiopsis subvermispora. J. Microbiol. Biotechnol. Food Sci. 2014, 3, 84-87.

226. Tovar-Herrera, O.E.; Martha-Paz, A.M.; Pérez-LLano, Y.; Aranda, E.; Tacoronte-Morales, J.E.; Pedroso-Cabrera, M.T.; Arévalo-Niño, K.; Folch-Mallol, J.L.; Batista-García, R.A. Schizophyllum commune: An unexploited source for lignocellulose degrading enzymes. MicrobiologyOpen 2018, 7, e00637. [CrossRef] [PubMed]

227. Kalra, K.; Chauhan, R.; Shaves, M.; Sachdeva, S. Isolation of laccase producing Trichoderma spp. and effect of $\mathrm{pH}$ and temperature on its activity. Int. J. Chem. Environ. Technol. 2013, 5, 2229-2235.

228. Zeng, S.; Zhao, J.; Xia, L. Simultaneous production of laccase and degradation of bisphenol A with Trametes versicolor cultivated on agricultural wastes. Bioprocess Biosyst. Eng. 2017, 40, 1237-1245. [CrossRef] [PubMed]

229. Adekunle, A.E.; Zeng, C.; Guo, C.; Liu, C. Laccase production from Trametes versicolor in solid-state fermentation of steam-exploded pretreated cornstalk. Waste Biomass. Valori. 2017, 8, 153-159. [CrossRef]

230. Aâssi, D.; Zouari-Mechichi, H.; Frikha, F.; Rodriguez-Couto, S.; Mechichi, T. Sawdust waste as a low-cost support- substrate for laccases production and adsorbent for azo dyes decolorization. J. Environ. Health Sci. 2016, 14, 1-12.

231. Karp, S.G.; Faraco, V.; Amore, A.; Letti, L.A.J.; Soccol, V.T.; Soccol, C.R. Statistical optimization of laccase production and delignification of sugarcane bagasse by Pleurotus ostreatus in solid-state fermentation. Biomed. Res. Int. 2015, 2015, 181-204. [CrossRef]

232. Moilanen, U.; Winquist, E.; Mattila, T.; Hatakka, A.; Eerikäinen, T. Production of manganese peroxidase and laccase in a solid-state bioreactor and modeling of enzyme production kinetics. Bioprocess Biosyst. Eng. 2015, 38, 57-68. [CrossRef]

233. Hariharan, S.; Padma, N. Optimization of lignin peroxidase, manganese peroxidase, and Lac production from Ganoderma lucidum under solid state fermentation of pineapple leaf. Bioresouyces 2013, 8, 250-271. [CrossRef]

234. Usha, K.Y.; Praveen, K.; Rajasekhar Reddy, B. Enhanced production of ligninolytic enzymes by a mushroom Stereum ostrea. Biotechnol. Res. Int. 2014, 2014, 815495. [CrossRef]

235. Asgher, M.; Asad, M.J.; Legge, R.L. Enhanced lignin peroxidase synthesis by Phanerochaete chrysosporium in solid state bioprocessing of a lignocellulosic substrate. World J. Microbiol. Biot. 2006, 22, 449-453. [CrossRef]

236. Silva, E.M.; Martins, S.F.; Milagres, A.M.F. Extraction of manganese peroxidase produced by Lentinula edodes. Bioresour. Technol. 2008, 99, 2471-2475. [CrossRef] [PubMed]

237. Robinson, T.; Nigam, P.S. Remediation of textile dye waste water using a white-rot fungus Bjerkandera adusta through solid-state fermentation (SSF). Appl. Biochem. Biotechnol. 2008, 151, 618-628. [CrossRef] [PubMed]

238. Ferreira da Silva, I.; Rodrigues da Luz, J.M.; Oliveira, S.F.; Humberto de Queiroz, J.; Kasuya, M.C.M. High-yield cellulase and LiP production after SSF of agricultural wastes by Pleurotus ostreatus using different surfactants. Biocatal. Agric. Biotechnol. 2019, 22, 101428. [CrossRef]

239. Mehboob, N.; Asad, M.; Imran, M.; Gulfraz, M.; Wattoo, F.H.; Hadri, S.H.; Asghar, M. Production of lignin peroxidase by Ganoderma leucidum using solid state fermentation. Afr. J. Biotechnol. 2011, 10, 9880-9887.

240. Coconi-Linares, N.; Magaña-Ortíz, D.; Guzmán-Ortiz, D.A.; Fernández, F.; Loske, A.M.; Gómez-Lim, M.A. High-yield production of manganese peroxidase, lignin peroxidase, and versatile peroxidase in Phanerochaete chrysosporium. Appl. Microbiol. Biotechnol. 2014, 98, 9283-9294. [CrossRef]

241. Gochev, V.K.; Krastanov, A.I. Fungal laccases. Bulg. J. Agric. Sci. 2007, 13, 75-83.

242. Zheng, Y.; Guo, M.; Zhou, Q.; Liu, H. Effect of lignin degradation product sinapyl alcohol on laccase catalysis during lignin degradation. Ind. Crops Prod. 2019, 139, 111544. [CrossRef]

243. Zhu, Z.; Li, N.; Li, W.; Li, J.; Li, Z.; Wang, J.; Tang, X. Laser mutagenesis of Phellinus igniarius protoplasts for the selective breeding of strains with high laccase activity. Appl. Biochem. Biotechnol. 2020, 190, 584-600. [CrossRef] 
244. Palma, C.; Lloret, L.; Sepúlveda, L.; Contreras, E. Production of versatile peroxidase from Pleurotus eryngii by solid-state fermentation using agricultural residues and evaluation of its catalytic properties. Prep. Biochem. Biotechnol. 2016, 46, 200-207. [CrossRef]

245. Rich, J.O.; Anderson, A.M.; Berhow, M.A. Laccase-mediator catalyzed conversion of model lignin compounds. Biocat. Agric. Biotechnol. 2016, 5, 111-115. [CrossRef]

246. Song, Q.; Deng, X.; Song, R. Expression of Pleurotus ostreatus laccase gene in Pichia pastoris and Its degradation of corn stover lignin. Microorganisms 2020, 8, 601. [CrossRef] [PubMed]

247. Barrios-Estrada, C.; de Jesus Rostro-Alanis, M.; Munoz-Gutierrez, B.D.; Iqbal, H.M.N.; Kannan, S.; Parra-Saldivar, R. Emergent contaminants: Endocrine disruptors and their laccase-assisted degradation-A review. Sci. Total Environ. 2018, 612, 1516-1531. [CrossRef] [PubMed]

248. Leonowicz, A.; Cho, N.; Luterek, J.; Wilkolazka, A.; Wojtas-Wasilewska, M.; Matuszewska, A.; Hofrichter, M.; Wesenberg, D.; Rogalski, J. Fungal laccase: Properties and activity on lignin. J. Basic Microbiol. 2001, 41, 185-227. [CrossRef]

249. Shraddha Shekher, R.; Sehgal, S.; Kamthania, M.; Kumar, A. Laccase: Microbial sources, production, purification, and potential biotechnological applications. Enzyme Res. 2011, 217861. [CrossRef]

250. Ardon, O.; Kerem, Z.; Hadar, Y. Enhancement of lignin degradation and laccase activity in Pleurotus ostreatus by cotton stalk extract. Can. J. Microbiol. 1998, 44, 676-680. [CrossRef]

251. Gunjal, A.B.; Patil, N.N.; Shinde, S.S. Ligninase in Degradation of Lignocellulosic Wastes. In Enzymes in Degradation of the Lignocellulosic Wastes; Springer International Publishing: Cham, Switzerland, 2020.

252. Zheng, F.; An, Q.; Meng, G.; Wu, X.; Dai, Y.; Si, J.; Cui, B. A novel laccase from white rot fungus Trametes orientalis: Purification, characterization, and application. Int. J. Biol. Macromol. 2017, 102, 758-770. [CrossRef]

253. Dias, A.A.; Matos, A.J.S.; Fraga, I.; Sampaio, A.; Bezerra, R.M.F. An easy method for screening and detection of laccase activity. Open Biotechnol. J. 2017, 11, 89-93. [CrossRef]

254. Dias, A.A.; Bezerra, R.M.; Pereira, A.N. Activity and elution profile of laccase during biological decolorization of olive mill wastewater. Bioresour. Technol. 2004, 92, 7-13. [CrossRef]

255. Minussi, R.C.; Pastore, G.M.; Duran, N. Potential applications of laccase in the food industry. Trends Food Sci. Technol. 2002, 13, 205-216. [CrossRef]

256. Datta, R.; Kelkar, A.; Baraniya, D.; Molaei, A.; Moulick, A.; Meena, R.S.; Formanek, P. Enzymatic Degradation of Lignin in Soil: A Review. Sustainability 2017, 9, 1163. [CrossRef]

257. Arora, D.S.; Gill, P.K. Comparison of two assay procedures for lignin peroxidase. Enzyme Microb. Technol. 2001, 28, 602-605. [CrossRef]

258. Zhao, M.; Zhang, C.; Zeng, G.; Huang, D.; Xu, P.; Cheng, M. Growth, metabolism of Phanerochaete chrysosporium and route of lignin degradation in response to cadmium stress in solid-state fermentation. Chemosphere 2015, 138, 560-567. [CrossRef] [PubMed]

259. Kong, W.; Chen, H.; Lyu, S.; Ma, F.; Yu, H.; Zhang, X. Characterization of a novel manganese peroxidase from white-rot fungus Echinodontium taxodii 2538, and its use for the degradation of lignin-related compounds. Process Biochem. 2016, 51, 1776-1783. [CrossRef]

260. Burlacu, A.; Israel-Roming, F.; Cornea, C.P. Depolymerization of kraft lignin with laccase and peroxidase: A review. Sci. Bull. Ser. F Biotechnol. 2018, 22, 172-179.

261. Brink, D.P.; Ravi, K.; Lidén, G.; Gorwa-Grauslund, M.F. Mapping the diversity of microbial lignin catabolism: Experiences from the eLignin database. Appl. Microbiol. Biotechnol. 2019, 103, 3979-4002. [CrossRef] [PubMed]

262. Herzog, V.; Fahimi, H.D. A new sensitive colorimetric assay for peroxidase using 3,3'-diaminobenzidine as hydrogen donor. Anal. Biochem. 1973, 55, 554-562. [CrossRef]

263. De Jong, E.; Field, J.A.; de Bont, J.A. Evidence for a new extracellular peroxidase manganese-inhibited peroxidase from the white-rot fungus Bjerkandera sp. BOS 55. FEBS Lett. 1992, 299, 107-110. [CrossRef]

264. Rajan, A.; Kurup, J.G.; Abraham, T.E. Solid state production of manganese peroxidases using arecanut husk as substrate. Braz. Arch. Biol. Technol. 2010, 53, 555-562. [CrossRef]

265. Kuhar, F.; Castiglia, V.C.; Zamora, J.C. Detection of manganese peroxidase and other exoenzymes in four isolates of Geastrum (Geastrales) in pure culture. Rev. Argent. Microbiol. 2016, 48, 274-278. [CrossRef]

266. Busse, N.; Wagner, D.; Kraume, M.; Czermak, P. Reaction kinetics of versatile peroxidase for the degradation of lignin compounds. Am. J. Biochem. Biotechnol. 2013, 9, 365-394. [CrossRef] 
267. Giardina, P.; Palmieri, G.; Fontanella, B.; Rivieccio, V.; Sannia, G. Manganese peroxidase isoenzymes produced by Pleurotus ostreatus grown on wood sawdust. Arch. Biochem. Biophys. 2000, 376, 171-179. [CrossRef] [PubMed]

268. Ravichandran, A.; Sridhar, M. Versatile peroxidases: Super peroxidases with potential biotechnological applications-A mini review. J. Dairy Vet. Anim. Res. 2016, 4, 277-280.

269. Chen, M.; Yao, S.; Zhang, H.; Liang, X. Purification and characterization of a versatile peroxidase from edible mushroom Pleurotus eryngii. Chin. J. Chem. Eng. 2010, 18, 824-829. [CrossRef]

270. Fisher, A.B.; Fong, S.S. Lignin biodegradation and industrial implications. AIMS Bioeng. 2014, 1, 92-112. [CrossRef]

271. Sugano, Y.; Muramatsu, R.; Ichiyanagi, A.; Sato, T.; Shoda, M. DyP, a unique dye-decolorizing peroxidase, represents a novel heme peroxidase family: ASP171 replaces the distal histidine of classical peroxidases. J. Biol. Chem. 2007, 282, 36652-36658. [CrossRef] [PubMed]

272. Chen, C.; Shrestha, R.; Jia, K.; Gao, P.F.; Geisbrecht, B.V.; Bossmann, S.H.; Shi, J.; Li, P. Characterization of dye-decolorizing peroxidase $(\mathrm{DyP})$ from Thermomonospora curvata reveals unique catalytic properties of A-type DyPs. J. Biol. Chem. 2015, 290, 23447-23463. [CrossRef]

273. Kim, S.J.; Shoda, M. Purification and characterization of a novel peroxidase from Geotrichum candidum Dec 1 involved in decolorization of dyes. Appl. Environ. Microbiol. 1999, 65, 1029-1035. [CrossRef]

274. Liers, C.; Pecyna, M.J.; Kellner, H.; Worrich, A.; Zorn, H.; Steffen, K.T.; Hofrichter, M.; Ullrich, R. Substrate oxidation by dye-decolorizing peroxidases (DyPs) from wood- and litter-degrading agricomycetes compared to other fungal and heme-proteins. Appl. Microbiol. Biotechnol. 2013, 97, 5839-5849. [CrossRef]

275. Lauber, C.; Schwarz, T.; Nguyen, Q.K.; Lorenz, P.; Lochnit, G.; Zorn, H. Identification, heterologous expression and characterization of a dye-decolorizing peroxidase of Pleurotus sapidus. AMB Express 2017, 7, 164. [CrossRef]

276. Qin, X.; Luo, H.; Zhang, X.; Yao, B.; Ma, F.; Su, X. Dye-decolorizing peroxidases in Irpex lacteus combining the catalytic properties of heme peroxidases and laccase play important roles in ligninolytic system. Biotechnol. Biofuels 2018, 11, 302. [CrossRef] [PubMed]

277. Lončar, N.; Draškovic, N.; Božić, N.; Romero, E.; Simić, S.; Opsenica, I.; Vujcic, Z.; Fraaije, M.W. Expreesion and characterization of a dye-decolorizing peroxidase from Pseudomonas fluorescens Pf0-1. Catalysts 2019, 9, 463. [CrossRef]

278. Karmakar, M.; Ray, R.R. Current trends in research and application of microbial cellulases. Res. J. Microbiol. 2011, 6, 41-53. [CrossRef]

279. Zhang, L.; Xu, J.; Lei, L.; Jiang, Y.; Gao, F.; Zhou, G.H. Effects of xylanase supplementation on growth performance, nutrient digestibility and non-starch polysaccharide degradation in different Sections of the gastrointestinal tract of broilers fed wheat-based diets. Asian Aust. J. Anim. Sci. 2014, 27, 855-861. [CrossRef]

280. Van Zyl, W.H.; Rosea, S.H.; Trollopeb, K.; Gorgensb, J.F. Fungal $\beta$-mannanases: Mannan hydrolysis, heterologous production and biotechnological applications. Process Biochem. 2010, 45, 1203-1213. [CrossRef]

281. Jayasekara, S.; Ratnayake, R. Microbial cellulases: An overview and applications. In Cellulose; Pascual, A.R., Martin, M.E.E., Eds.; Intechopen: London, UK, 2019; pp. 1-21.

282. Daba, A.S.; Youssef, G.A.; Kabeil, S.S.; Hafez, E.E. Production of recombinant cellulase enzyme from Pleurotus ostreatus (Jacq.) P. Kumm. (type NRRL-0366). Afr. J. Microbiol. Res. 2011, 5, 1197-1202.

283. Sharma, H.P.; Patel, H.; Sharma, S. Enzymatic extraction and clarification of juice from various fruits-A review. Trends Post Harvest Technol. 2014, 2, 1-14.

284. Shi, H.; Ding, H.; Huang, Y.; Wang, L.; Zhang, Y.; Li, X.; Wang, F. Expression and characterization of a GH43 endo-arabinanase from Thermotoga thermarum. BMC Biotechnol. 2014, 14, 35. [CrossRef]

285. Saleem, F.; Ahmed, S.; Jamil, A. Isolation of a xylan degrading gene from genomic DNA library of a thermophilic fungus Chaetomium thermophile ATCC 28076. Pak. J. Bot. 2008, 40, 1225-1230.

286. Khanongnuch, C.; Sanguansook, C.; Lumyong, S. Nutritive quality of $\beta$-mannanase treated copra meal in broiler diets and effectiveness on some fecal bacteria. Int. J. Poult. Sci. 2006, 5, 1087-1091.

287. Järvinen, J.; Taskila, S.; Isomäki, R.; Ojamo, H. Screening of white-rot fungi manganese peroxidases: A comparison between the specific activities of the enzyme from different native producers. AMB Express 2012, 2, 62. [CrossRef] [PubMed] 
288. Martinez, D.; Larrondo, L.F.; Putnam, N.; Gelpke, M.D.S.; Huang, K.; Chapman, J.; Helfenbein, K.G.; Ramaiya, P.; Detter, C.J.; Larimerm, F.; et al. Genome sequence of the lignocellulose degrading fungus Phanerochaete chrysosporium strain RP78. Nature 2004, 22, 695-700.

289. Iimura, Y.; Sonoki, T.; Habe, H. Heterologous expression of Trametes versicolor laccase in Saccharomyces cerevisiae. Protein Expr. Purif. 2018, 141, 39-43. [CrossRef] [PubMed]

(C) 2020 by the authors. Licensee MDPI, Basel, Switzerland. This article is an open access article distributed under the terms and conditions of the Creative Commons Attribution (CC BY) license (http://creativecommons.org/licenses/by/4.0/). 